Historic, Archive Document

Do not assume content reflects current scientific knowledge, policies, or practices. 



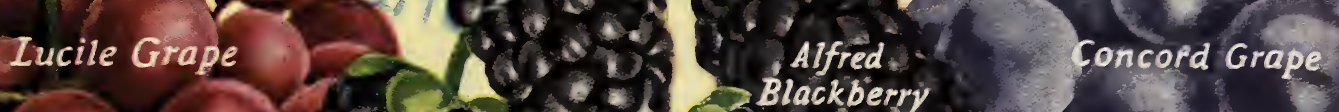

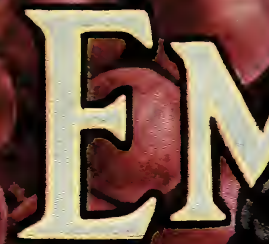

\section{Selected Thits or Farm and Garders}

aforin

$(M(-), 2)$

$(x+2)$ ?

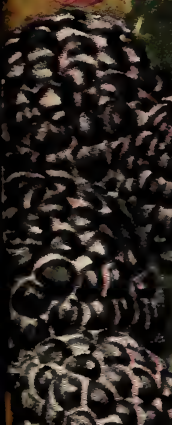

-

Mastodón Strawberry

* répisas

* (nypes.

Cumberland Ráspberfy

- 5 - 5 cum

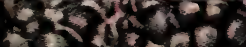

163

cof(s)

(joger)

A Fruit Garden Completes Your Home
Plant One This Spring. See pages 13, 14, 15, 21, 34, 35
for SPECIAL PRICED BARGAIN COLLECTIONS

$+10060$

oplatas

$x-3=-1,4$

If Statham Raspbery

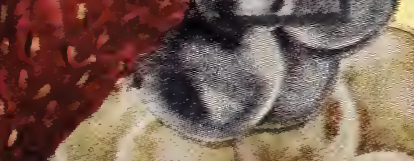

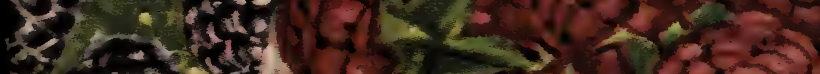

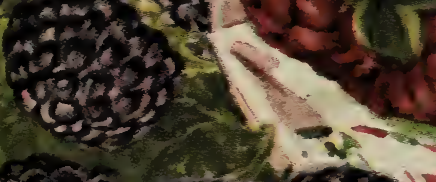

SA

HENASZ EMLONG E SONS STEVENSWULLE: MICHIGAN int 150 - 


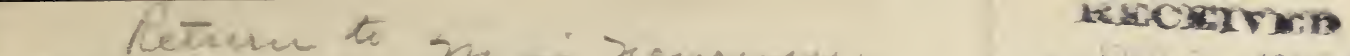 \\ This Outstanding Strawberry}

will Bring Thousands of Dollars
to Fruit Growers and Gardeners

We consider it a great honor and a real privilege to give our many thousands of friends and customers the first opportunity to plant HARVEST KING, the King of all June-bearing Straw. berries. Heretofore the average grower has only read or heard about those tremendous yields of 500 crates and profits of $\$ 1000.00$ to $\$ 1500.00$ per acre, but now when you plant HAR. VEST KING you can realize those big crops and big profits your. self.

In every class of fruit you are familiar with you can readily name the one outstanding variety that is vastly superior to all others, one that combines all of the desirable features, yet none of the faults-in peaches the ONE variety is Elberta, in grapes Concord, in apples Delicious, and in strawberries it will be HARVEST KING.

Like all truly great varieties HARVEST KING is not a scientific production, it just "happened", and in this instance nature seems to have outdone itself in generosity because HARVEST KING seems to possess all of the desirable qualities found in other strawberries with a few more added for good measure.

Rugged Vitality Assures Big Crops Under All Conditions

Probably the one greatest outstanding feature to make HARVEST KING the leader of all Junebearing strawberries is the unusual vitality of the plant. During our exhaustive tests with this variety it has been subjected to all manner of hardship and adverse conditions, yet it has never failed to make a heavy, uniform fruiting row and produce an enormous crop of finest quality fruit.

\section{Late Blooming Season Defies Spring Frosts}

Originating in Northern Michigan where late Spring frosts are common and Summers short, HARVEST KING protects itself by blooming late and then maturing the fruit rapidly to ripen with Gibson, Dunlap and other midseason sorts. It is an ideal companion for Premier as you will be in position to supply your customers with fancy berries late into the season. The berries greatly resemble Premier in size, color, shape and quality.

\section{Heaviest Bearing of All Commercial Varieties}

-Even much more productive than Premier, Gibson, Dunlap or Dr. Burrill. When you first see HARVEST KING plants bearing, you will marvel (as we did) at the enormous load of big red beauties produced by every plant. It is a perfect flowering or male variety and can be grown alone. Foliage is healthy and abundant. giving ample protection to both bud and fruit. Fruit stems are semi-rigid, assuring clean fruit with lustrous color.

\section{A Fancy Berry Commanding Premium Prices}

To illustrate the superior color, quality and attractiveness of HARVEST KING we need only state conditions on the Detroit market last Spring. When such varieties as Gibson, Dunlap, etc., were selling for $\$ 3.50$ to $\$ 5.00$ per 24 -quart crate, HARVEST KING were snapped up readily at $\$ 7.00$, buyers are willing to pay for quality and you will find an eager market for all of the HARVEST KING you can produce for many years.

\section{The Greatest Canning Berry on Record}

HARVEST KING not only excels in a commercial way, it is also in a class by itself for those wishing to grow strawberries for home use only. In addition to the heavy fruiting quality, which assures a generous supply of berries from only a small planting, the attractive deep red color, delicious fiavor, and large size will give you greater pleasure and satisfaction than you have ever known before. As a canning berry HARVEST KING stands supreme, requiring less sugar than any other variety, retaining their original fine flavor and appearance even after cooking. No matter what your requirements in a Strawberry may be, HARVEST KING will fill the bill. You will learn this to your complete satisfaction after you grow it, as you eventually will. It is the real MONARCH of all June-bearing StrawberriesPast-Present-or Future. 


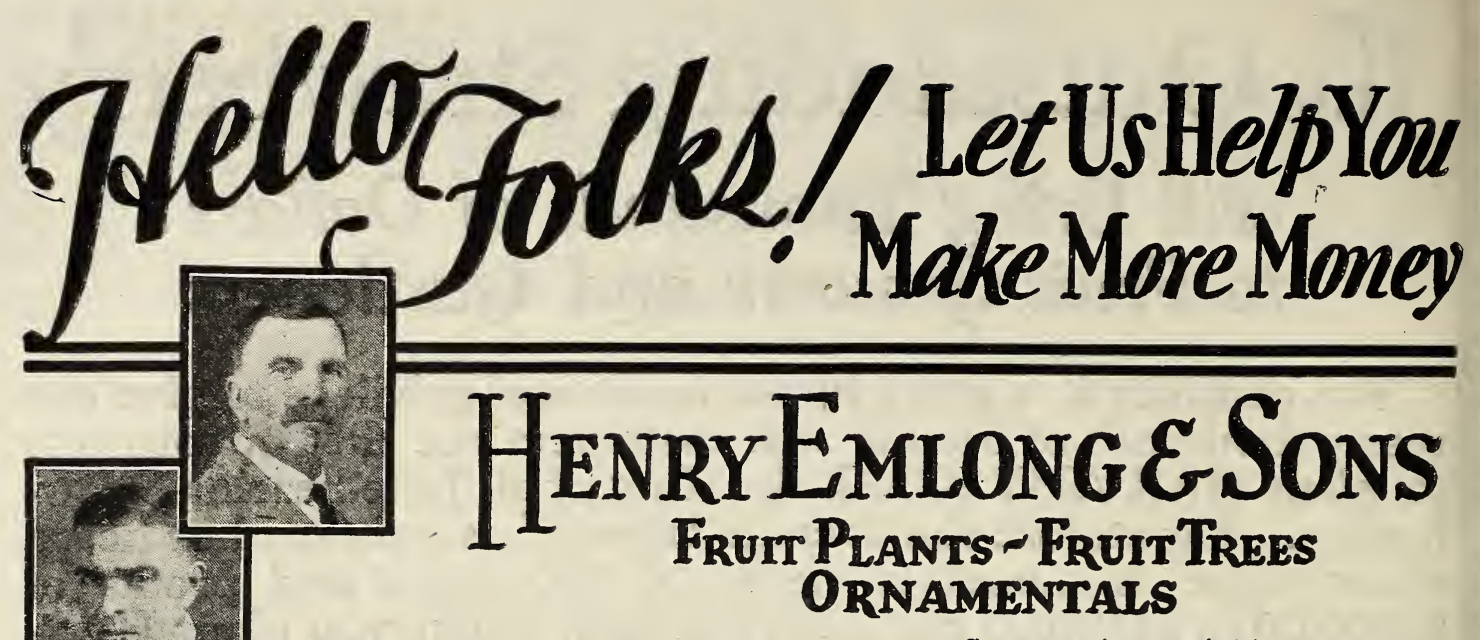

Stevensville, Michigan, I929.

MONEY is one thing we are all mighty interested in. A few hundred dollars "salted" away for a rainy day saves a lot of worry. "Sure thing," you'll say, "anyone will agree with that. But-the big idea is, HOW to get it?"

Just FIVE words answers the question-and here they are: GET INTO THE FRUIT BUSINESS!

Right there is the solution to your whole problem, and if you heed this advice you will have money to buy the things your family wants and deserves. But what is more important-you will have MONEY IN THE BANK to take care of any emergency that may arise.

FRUIT GROWING is the one branch of agriculture that PAYS A BIG PROFIT-and always will! Why not get into the successful money-making class? Stop plodding along, losing time and money on ordinary crops that hardly pay taxes, let alone showing a profit.

Sure enough, it's true that some folks are failures in the fruit business. But you will agree with me that some automobiles will easily make a speed of 80 miles an hour, while others will not do 40 down hill.

Some plants and trees will produce big paying crops of fruit, while others will hardly pay for the cost of growing then.. There is the secret of fruit growing profits. Our long experience has taught us how to put the BIG CROPS into plants and trees-and we have proven this fact to thousands of fruit growers and gardeners in every section of the country.

So if you want more money-MAKE IT IN FRUIT. Your banker will tell you the same thing. GET INTO THE FRUIT BUSINESS. But to make certain that you are starting out on the "right foot" plant our PERFECTED BIG-YIELDING STRAINS.

\section{Yours very truly,}

H. Southerland of Jonesboro, Ind., planted 2000 plants and sold over $\$ 600$ worth of berries. This is better than $\$ 2000$ per acre.

Emlong's Plants and Trees produce big crops because all drones have been eliminated by careful selection.

HENRY EMLONG \& SONS.

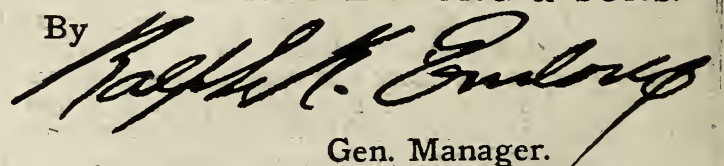




\section{Time}

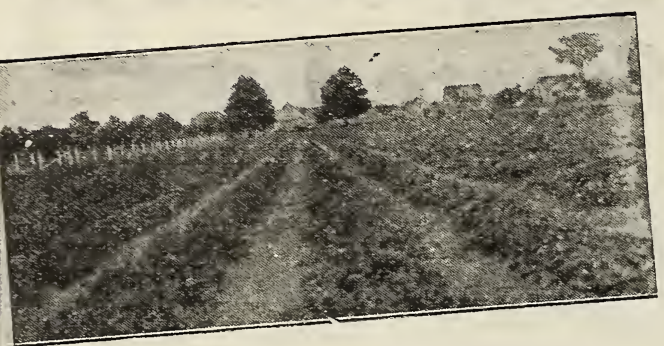

Why do some plants and trees produce big crops-and others very little? It's all in the breeding. You can improve berry plants and fruit trees just as easy as you can horses, hogs or corn. By means of careful selection we have greatly increased the fruiting capacity of every variety we offer. All drones and unproductive plants have been eliminated. Every Emlong plant and tree produces a full crop of strictly first quality fruit.

\section{I00 Per Cent Double your crops - 1 Mealths and profits by plant- ing disease-free stock. Healthy plants and trees will give you big profits for many years, while on the ather hand many of the failures in the fruit business can be traced directly to the diseased stock that was planted. We know the importance of planting healthy stock, therefore, take every precaution to prevent disease.}

\section{Per Cent Vigorous}

Every Emlong plant, tree, shrub or vine has a perfect root system and that is why thousands of growers have succeeded with our stock after failing with others. Our ideal soil and ex- clusive methods of culture and propagation provide every Emlong production with an ideal root system that makes your success certain even under the most unfavorable conditions.

\section{100 Per Cent Hardy}

Ask anybody that knows and they will tell you that our hardy, Northern grown nursery stock is the most dependable, the most productive, and the most profitable that can be obtained. Our mild, even temperature during the growing season brings our stock to perfect maturity and every specimen is strong, stocky, sturdy and evenly proportioned.

\section{- 100 Per Cent 3. True to Name}

Our reputation for reliability and honest, fair and square treatment has never been questioned and when you place your confidence in Henry Emlong \& Sons, you are going to get exactly what you order. If we cannot furnish it we will tell you so. Keeping our stock pure and true-to-name is a big business in itself but that we do it is attested by the thousands of customers who order from us year after year.

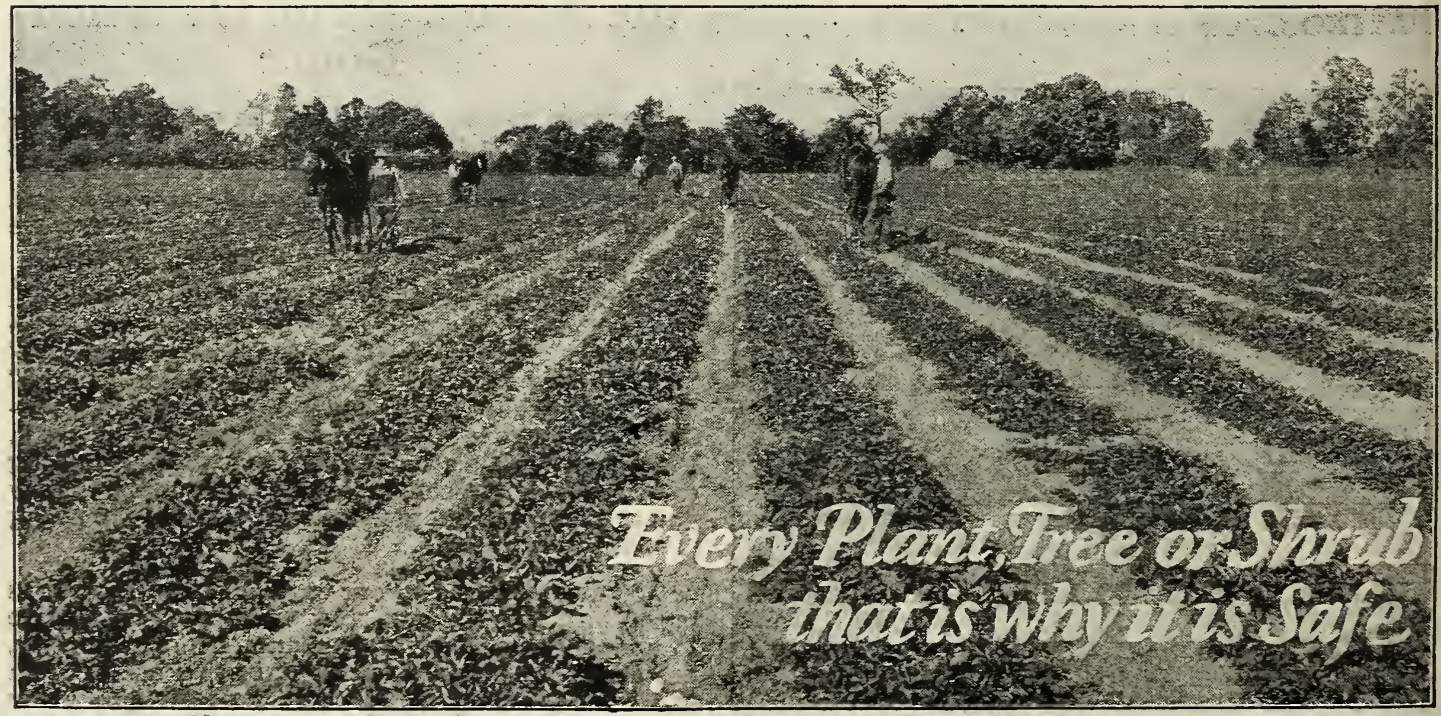




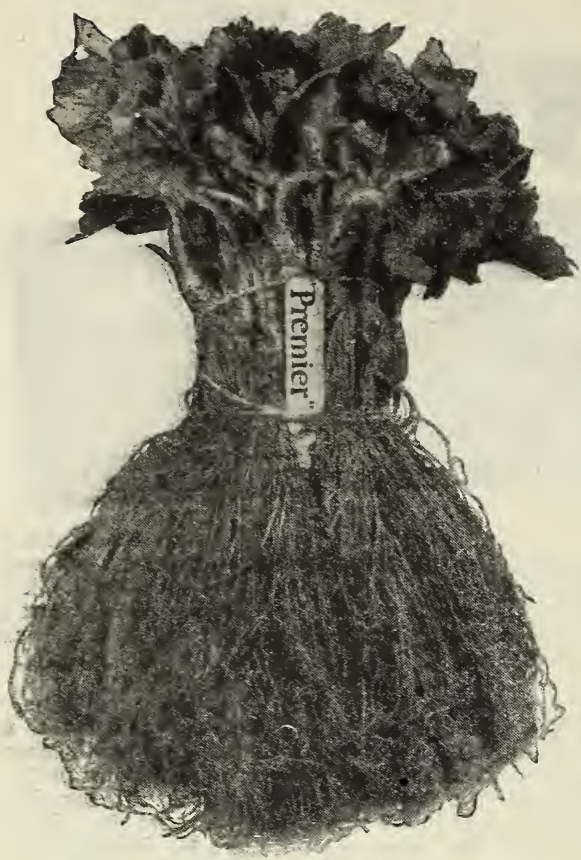

25 of Our Premier Trimmed for Packing. Big Crowns and Plenty of Roots.

\section{We Give You ALL of the ROOTS andALLofine LIFE}

You might just as well buy a three-legged horse or build a house with only half a foundation as to plant nursery stock that has been carelessly grown, carelessly dug and then carelessly packed.

Every Plant, Tree, Shrub or Vine is a living oragnism that must eat and breathe and your success, failure, satisfaction or disappointment will be determined almost entirely by the care your stock has had while growing in the nursery.

Plain old-fashioned, every day common sense will tell you that a tree or plant with ALL of its roots will grow faster, live longer, produce more fruit and better fruit than one that has been injured while digging, left in the sun and wind to dry out and then packed in a don't care, haphazard manner.

Natural advantages such as ideal soil, a long growing season and abundant rainfall are all mighty important factors in helping us produce trees and plants of the highest qualitystock that has a national reputation for vigor, health and productiveness.

However, natural advantages alone are not responsible for our success and the success of our thousands of customers. Two generations of EMLONG'S combining more than 100 years of actual experience have given their undivided attention to growing the best stock man and nature can produce, and then digging, handling and packing in such a manner that will assure 100 per cent satisfaction.

We know that the roct system contains the life of any plant, tree or shrub. The more roots you get the more life it has. We have devised our own methods of digging so that we get all of the roots without injuring any other part of the plant or tree. After digging the stock is handled promptly and carefully, to protect from sun and wind. Packing is done by experts. Plenty of damp specially prepared moss is used, and you will marvel at the fresh, crisp appearance of every Plant, Tree or Shrub when you receive it.

In order to be satisfied and successful you must plant stock that has been grown right. dug right and packed right. More than 50 years at it has taught us the "know how." Read what our customers say on the opposite page.
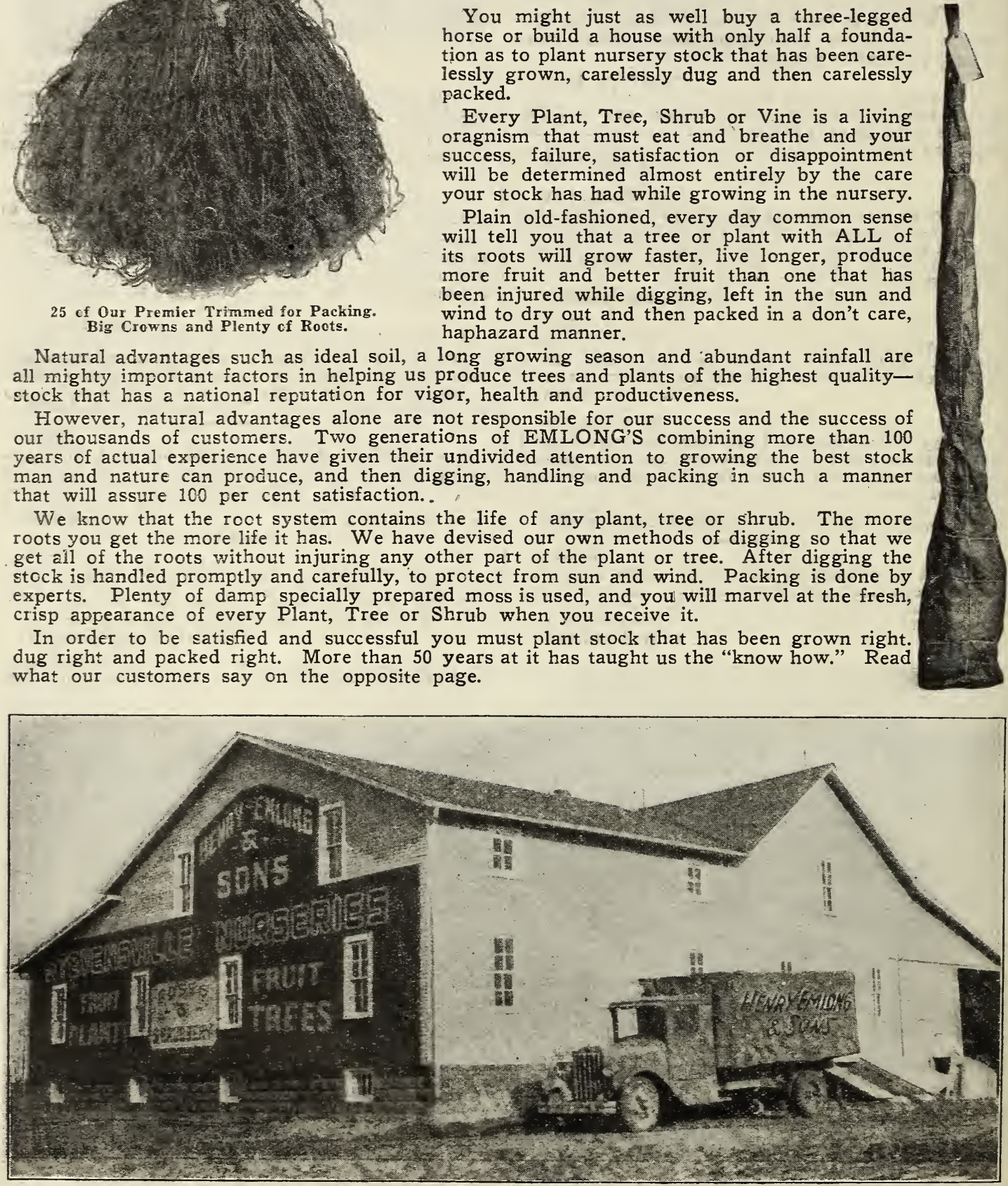

All Stock is Hauled Frcm Fields to Packing House in Wind Proof Covered Trucks Where It is Graded and Carefully Packed 


\section{That Is Why Every Emlong Customer Is a Satisfied Customer}

Here are just a few of the thousands of letters we receive from our customers. They will tell you the whole story about EMLONG QUALITY, EMLONG SERVICE and EIMLONG RELIABILITY.

\section{About the Dollars}

The 1500 strawberry plants purchased from you last year produced a marvelous crop. We sold 2500 quarts of fancy berries at an average price of $\$ 4.50$ per crate. This is at the rate of 10,000 quarts per acre and an income of over $\$ 1600.00$. H. H. Krumwiede, Excelsior, Minn.

A few years ago I sent to you for plants and they were wonderful. They have produced at the rate of over $\$ 1,200.00$ per acre. That is one reason why all the people around here are sending to you for plants.

E. E. Meese, Tuscarawas, Ohio.

Your Raspberry plants are just wonderful. The 400 plants made an astonishing growth. We sold $\$ 98.00$ worth of berries the first year besides having a generous supply for home use.

Mrs. W. L. Douglas, Greybull, Wyo.

From a patch of berries grown from your plants, less than two-thirds of an acre, we realized a profit of over $\$ 700.00$. Your plants are splendid yielders and fruit unusually large.

William Siefers, Davenport, Ia.

Your advice to "get into the fruit business" is right. Without previous experience I planted slightly over two acres to EMLONG'S plants and made a net profit of $\$ 2,150.00$. No trouble to make money when you start right.

C. L. Teckler, Crystal Lake, Ill.

\section{About Our Packing}

Have just received my trees and they are in fine shape. You are to be commended for your wonderful system of packing.

Miss Rika Wallen, Fairbanks, Alaska.

Your shipment number 19840 arrived in excellent condition. Your packing was far superior to that of shipments received from several other nurseries this season.

Wm. H. Comstock, Spring Valley, Minn.

I am pleased with the way you pack your trees for shipment. You are not afraid to use moss and moisture. Trees received from another nursery were all dried out.

$$
\text { F. J. Miles, Bellaire, Mich. }
$$

Received the plants in splendid condition. Your plants were packed better and they were more fresh than any plants. I have ever received. They could have made a trip around the world.

C. E. Smith, Eldon, Mo.

\section{About the Roots}

The plants you sent me were the finest I have ever seen. I buy from 12,000 to 18,000 plants every year and am so well pleased with your heavy rooted stock that you will get all of my future orders.

\section{A. B. Robertson, Wellsville, N. Y.}

Stock received and all set out. It is the best rooted stock ever received from any nursery and I will guarantee every one to' grow. Every one was large, fresh and good count.

C. J. Morgan, Woodland, Mich.

Order received and am more than pleased. Everything in perfect shape and had the best roots I ever saw. They are sure growing nice. L. D. Carter, Carterville, Ill.

Order received and everything planted. To say that we are pleased does not express it. Received trees and shrubs from several nurseries this Spring: but yours were by far the largest and best rooted of all.

\section{W. A. Palmer, Grantsburg, Wis.}

I must let you know that I received my strawberry plants in wonderful condition, and that I have never planted anything that started to grow so quick. They have several leaves and a few buds already. They just can't help it with roots such as they have. Needless to mention I am more than pleased because I have at last found a place to buy dependable plants and trees.

Walter H. Maas, Oroville, Calif.

\section{About Our Service}

Thanks very much for your prompt shipment and generous count. They are the finest plants we have ever planted. We know now where we can really get our money's worth.

John Tosetto \& Son, Canon City, Colo:

We received the nursery stock in fine condition, and are well pleased. We sure appreciate your prompt service.

T. Boulware \& Son, Molino, Mo.

I wish to thank you for giving my order such prompt and careful attention. Everything arrived in perfect condition and every plant is growing. Bruce Edwards, Perrysville, Ky.

Thanks very much for your promptness in filling my order. They are the finest and strongest looking plants I ever received and ought to be able to do wonderful with them.

F. O. Gessner, Forest Lake, Minn. 


\section{Four of the Greatest THE EMLONG STRAIN IS BETTER}
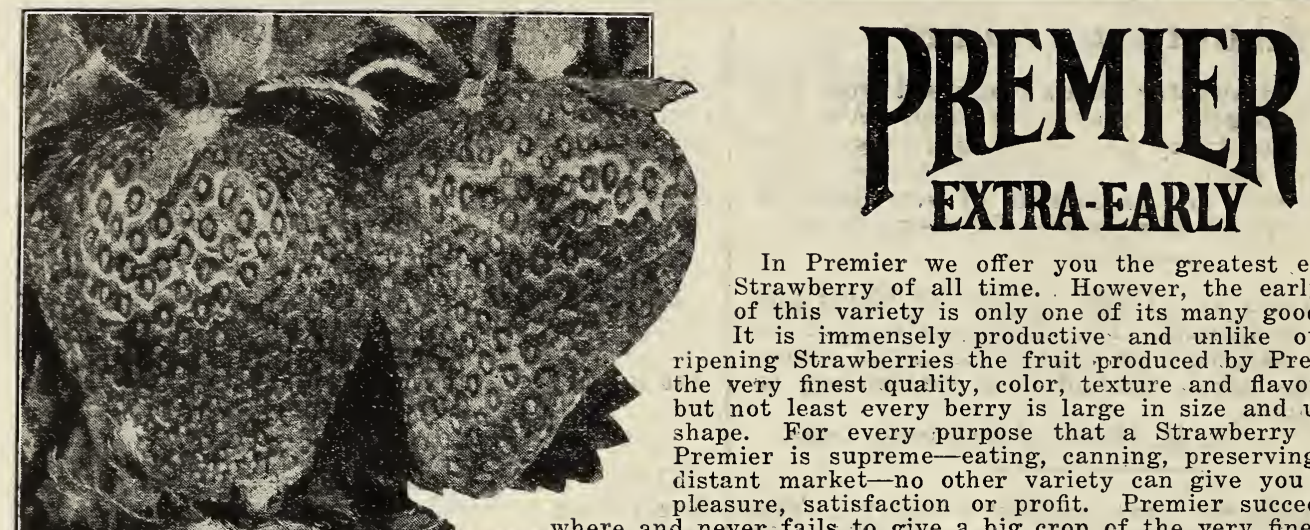

In Premier we offer you the greatest extra early Strawberry of all time. However, the early ripening of this variety is only one of its many good features. It is immensely productive and unlike other early ripening Strawberries the fruit produced by Premier is of the very finest quality, color, texture and flavor and last but not least every berry is large in size and uniform in shape. For every purpose that a Strawberry is wanted Premier is supreme-eating, canning, preserving, local or distant market-no other variety can give you any more pleasure, satisfaction or profit. Premier succeeds every-

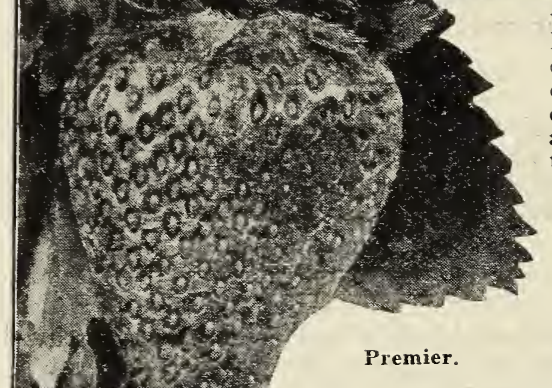
proper It is frost-proof, drought-proof, and even fool-proof-producing its customary big load of fruit even under the most unfavorable conditions. The foliage is tough and healthy and grows tall and rank, covering the blossoms and berries and protecting them from frost and scalding sun. From every angle Premier is solid gold, 18-karat, true-blue and will make big money for you.

MORE BIGGER BETTER BERRIES.

The Premier plants bought of you produced bigger berries and more of them than Premiers bought three other places. My friends all want your plants. A. Cadwalader, Corbin, Kansas.

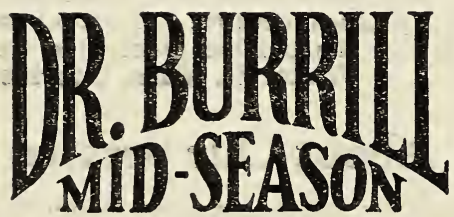

Perhaps the best recommendation we can give Dr. Burrill is to tell you that it is superior to Dunlap, the old-time favorite. In manner of plant growth the two are nearly identical, but Burrill produces larger berries and more of them, and is claimed by many to ripen a few days earlier. If you are looking for a really dependable variety-one that will produce profitable crops even under trying conditions-then plant Dr. Burrill. The plants are medium in size, deep rooted and exceptionally vigorous and healthy. Immensely productive. The berries are second to none in matter of quality, flavor, appearance and shipping qualities. A wonderful canning and eating variety. For Prices See Page 52.

\section{Nothing But the Best}

The varieties of Strawberries we offer are all staminate or perfect flowering and can be grown alone as they do not require mating. You will note that we are offering only nine varieties. After testing practically every variety "under the varieties. After testing practically every variety "under the cund we have found these nine varieties to be the very best, and in keeping with our policy TO OFFER EMLONG CUS-
TOMERS NOTHING BUT THE BEST we have discarded all others. When something better is found we will have it.

\section{.}

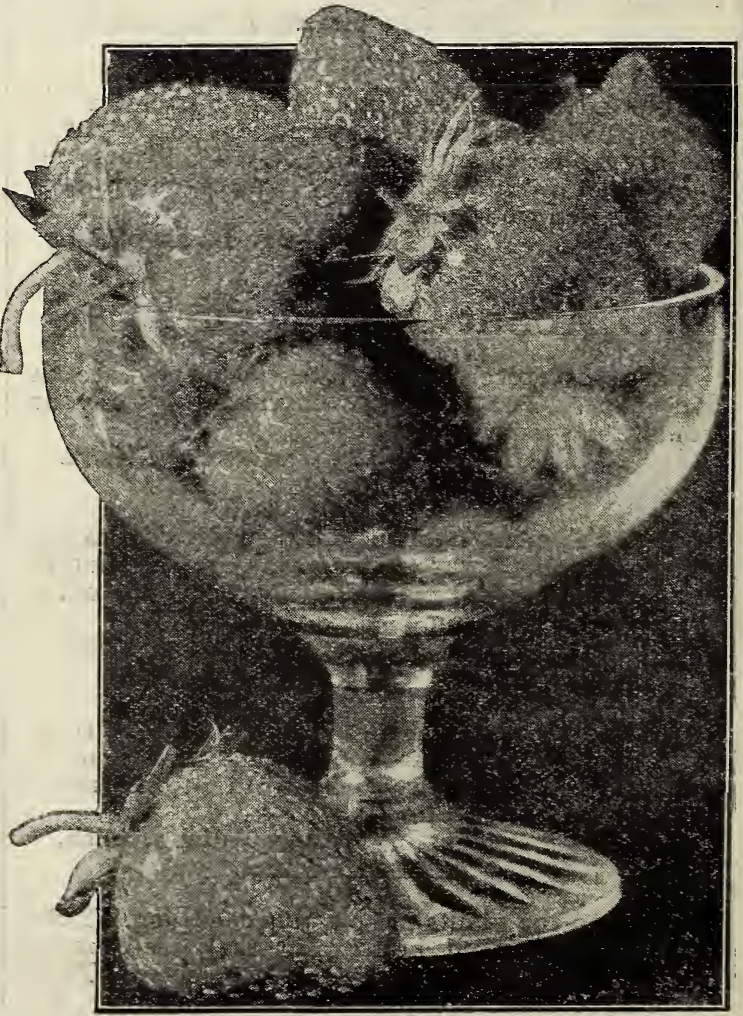

Dr. Burrill. 


\section{Strawberries on Record EVERY PLANT BEARS HEAVILY}

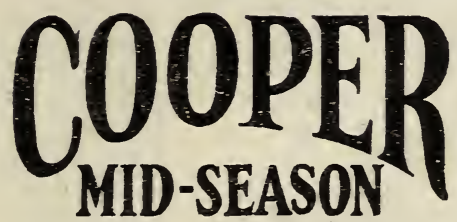

"The Stramberry With a Different, Delicious Flavor." Cooper is the elephant of the Strawberry family as it produces bigger berries, sweeter berries and more of them than any other variety. Introduced by us in 1922 it has become popular with little and big Strawberry growers, East, West, North and South. It has no preference for soil or climate, but adapts itself readily to all conditions. For home use Cooper is in a class by itself, and no other variety will make more crates or more dollars for commercial growers, Ripening in midseason with Gibson and Dunlap, Cooper is bearing heavily after these varieties are gone. The long fruiting season is due to the exceptional vigor of the plant-the long roots going down and down after moisture, carrying every berry to perfect maturity. The last berries are just as large as the first, 18 to 30 filling a quart box and many of them measuring 5 inches around. To know the full meaning of Strawberry satisfaction, plant Cooper this Spring. But-make sure you are planting the original Emlong Big Yielding Strain. For prices see page 52 .
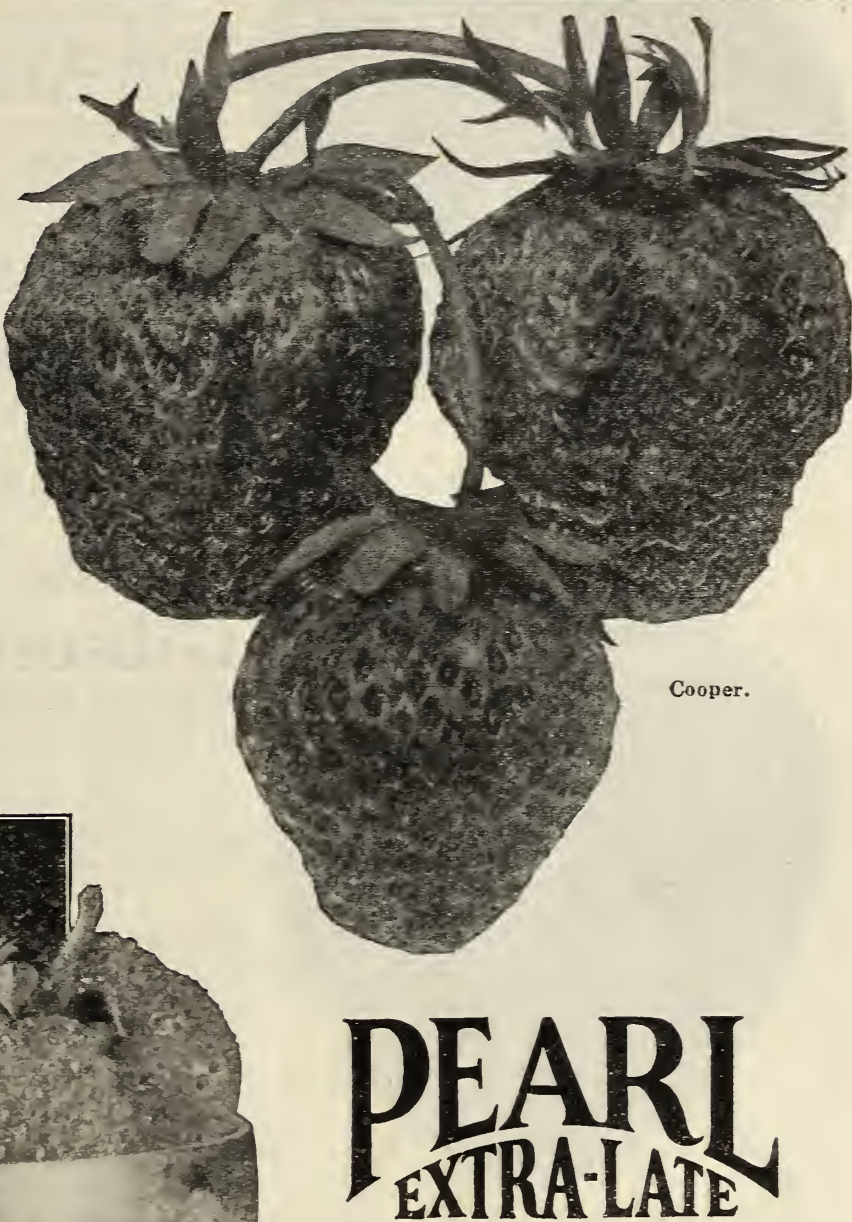

This extra late variety completes the circle wo have been rorking on for so many years-a late Strawberry that could be depended upon to produce quality and quantity-a big paying crop regularly, under all conditions. Whether you ar growing Strawberries for home use or for market a long fruiting season is desired and when you plant Premier, Cooper and Pearl you are planting the most profitable and longest-fruiting combination it is possible to obtain. Because of its late blooming season Pearl is the ideal variety for frosty locations. The immense foliage gives ample protection to both the bud and fruit. During our tests with this variety it has proven equally desirable for light or heavy soil. prolific in plant as well as fruit, it makes an ideal fruiting row under all conditions. The berries are large, uniform, solid and red clear through, and very attractive, with excellent flavor. Pearl prolongs your season and increases your profits : extra late berries always bring fancy prices. For prices see page 52 .

Emlong's Strawberry plants and other Nursery stock is all grown on high upland soil that is rich and well prepared Thi coupled with our special cultural methods equips our stock with many sturdy, fibrous roots that assures a quiak growth and big crops, even under the most unfavorable conditions. More than 53 years at it has taught us the "know how." We can guarantee your absolute satisfaction because our stock is grown right, dug right, and packed right. 


\section{Three Old Favorites}
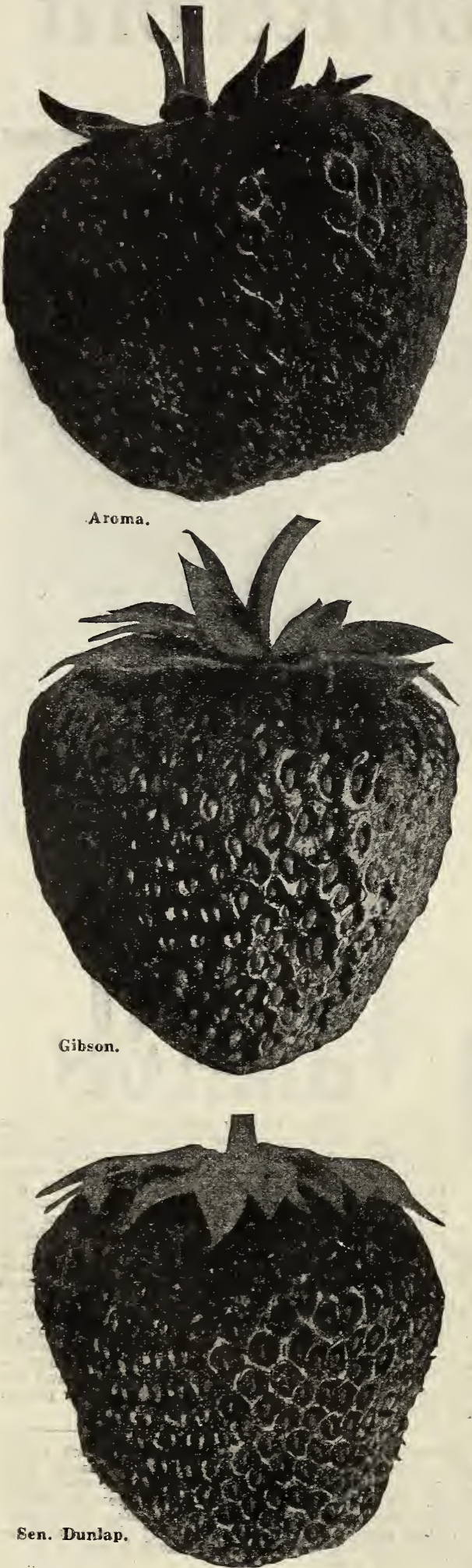

EMLONG'S

Aroma

LATE

This late Strawberry has long been a favorite market variety in Tennessee, Missouri and Arkansas, but is grown with equal success in every. other part of the country. Usually commanding premium prices on all markets, "it is one of the greatest of long distance shippers, owing to the supreme quality of the berries. It is also highly desirable and suitable for home use as there is something undescribably rich and pleasant about the flavor that commands the admiration of all. For prices see page 52 .

\section{EMLONG'S \\ Senator Dunlap} MEDIUM EARLY
During the past two decades Dunlap has made more crates and more dollars for strawberry growers than any other variety. If you are looking for a "rough and ready" strawberry that will thrive and produce a big crop of fine fruit, with but very little attention-plant Sen. Dunlap. For home use this variety is unsurpassed, fresh from the vines. Canned or preserved Dunlap is equally delicious. For price see page 52 .

\section{EMLONG'S

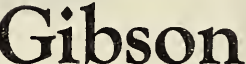
MEDIUM LATE a profitable crop. The plants are large and healthy; foliage strong, upright and abundant. Fruit is of the very finest color, quality, flavor and appearance, selling well on any market and mighty fine for home use. For prices see page 52 .

\section{How to Grow Strawberries}

Any soil that will produce garden truck or ordinary farm crops is suitable for strawberries. Prepare it the same as you do for garden seeds or other crops. The best fertilizer is well rotted stable manure, plowed or spaded under before the plants are set. The proper time to plant is April or May. For field culture the plants should be set 18 inches apart in the row with the rows $3 \mathrm{~T} / 2 \mathrm{ft}$. apart. This requires about 8,000 plants per acre. For garden culture they can be planted closer. In setting the plants use a spade to make an opening in the soil deep enough and wide enough to readily receive the roots. The crown of the plant should be even with the top of the soil and the roots spread fan shaped (see illustration at bottom of page) then press the dirt firmly on both sides of the plant with hands or feet. Remove the blossoms as fast as they appear until July. Hoe and cultivate at frequent intervals to destroy weeds and conserve moisture, nothing more is necessary. You will find it an easy matter to produce BIG CROPS with Emlong's plants because the big crops are there before you get them.

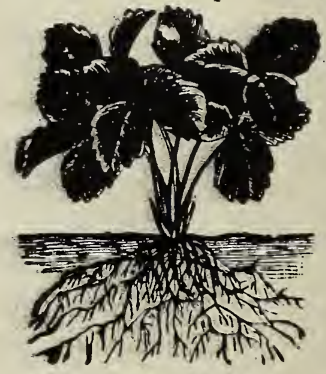

Strawberry Plant Properly Set. 


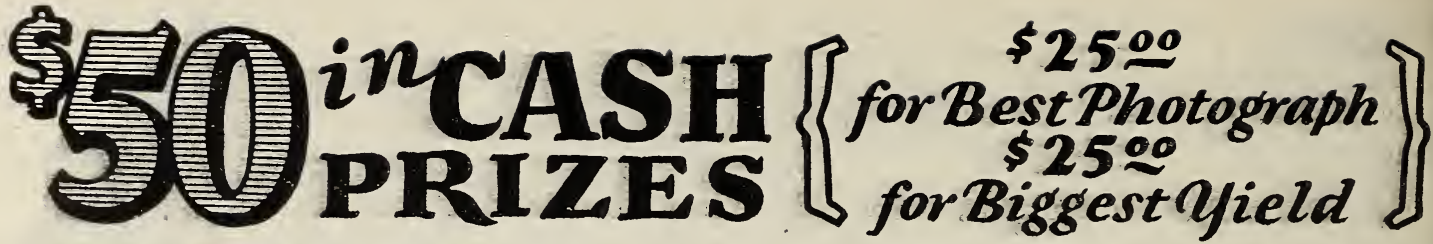

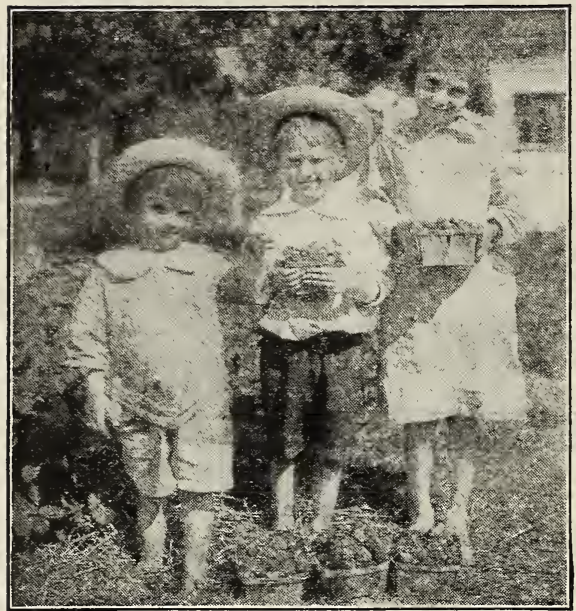

\section{:Emlong's Back Yard Garden}

If you have only a small' space available, this collection will give you a fine strawberry garden. Can be planted in a plot $20 \times 20$ feet square, and will assure you a big supply of delicious fruit from early to late during the strawberry season.

50 Premier ...................\$o.8o

50 Dr. Burrill ...................... 65

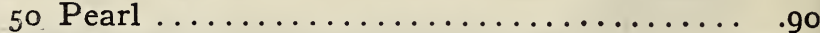

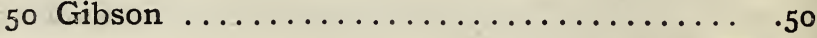

$\$ 2.85$

Special Price, only $\$ 2.35$

\section{Emlong's Bungalow Garden}

A yield of 650 quarts of beautiful berries is the record made by this collection. See if you can beat it. The Bungalow Garden has long been a favorite with our customers. To know why, you must plant it. Here is what you get:

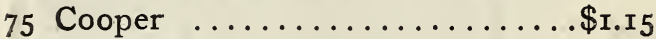

75 Premier ................ I.05

75 Aroma $\ldots \ldots \ldots \ldots \ldots \ldots \ldots \ldots . .85$

75 Dr. Burrill ............. 85

$\$ 3.90$

Special Price Only, \$3.35.

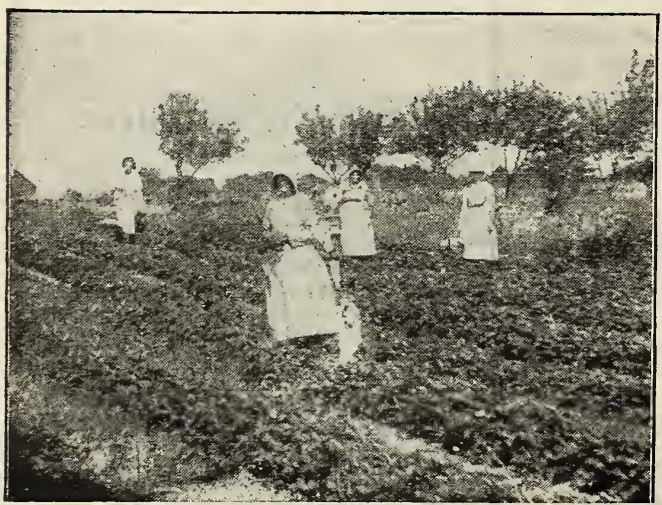

\section{Emlong's, Big Four Garden}

Here are the four varieties that have made strawberry growers independent. An ideal fruiting combination that will give you a continuous supply of finest quality berries from extra early to extra late. A year-round supply of berries for the largest family.

roo Premier ...............\$r.25

I00 Dr. Burrill ............... I.05

I0o Pearl ................... I.40

Ioo Cooper ................ I.40

Special Price, only $\$ 4.45$ 


\section{Here Is Your Opportunity}

Here is your opportunity to have a

Strawberry Garden without cost. Simply order the collection you want and then after the fruiting season write and tell us the number of quarts of berries you picked; send us a picture of the garden, or both. If you report the best yield or send in the best photograph you will win first prize of $\$ 15.00$. If you should win both first prizes you will get $\$ 30.00$. There will also be four \$5.00 prizes for second and third best. All pictures and reports must reach us before September 1st, 1930.

\section{Emlong's Suburban Garden}

A cash profit of $\$ 104.00$, in addition to supplying berries to a family of five is what the Suburban garden did for Mrs. E. C. Knowles of Nebraska. She says "No American family can afford to be without an Emlong Strawberry Garden.'

This garden consists of the following:

50 SENATOR DUNLAP .......... \$0.50

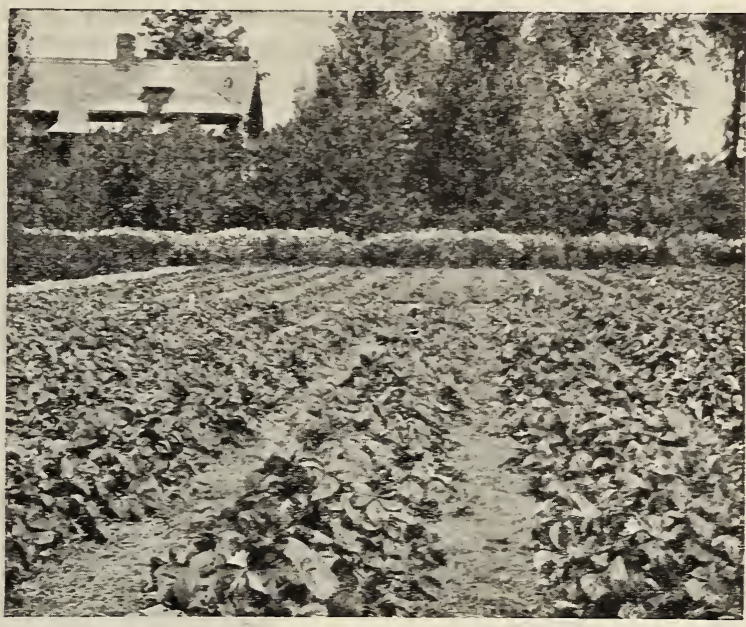

50 PREMIER

50 GIBSON

Special Price, only \$3.25.

.80

AROMA

50 HARVEST KING ............. 1.40

$\$ 3.85$

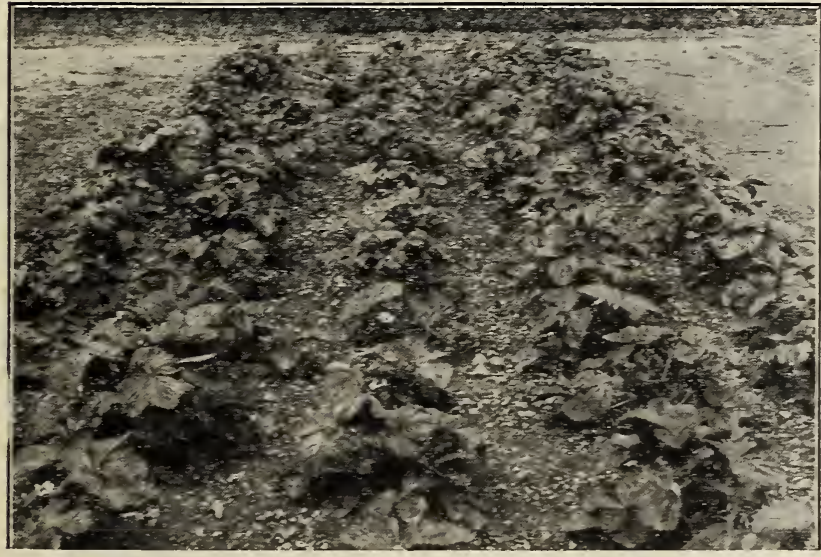

\section{Emlong's Combination Garden}

Plant our Combination Garden this Spring and you can have berries in September, October and November. Next year you will have plenty of berries during the regular strawberry season and then more berries in the Fall.

50 PREMIER

$\$ 0.80$

50 DR. BURRILL

50. PEARI

.90

100 PERFECTED MASTODON .. 2.75

$\$ 5.10$

Special Price, only $\$ 4.50$

\section{Emlong's Money-Maker Garden}

You will find this garden to be a BIG MONEY MAKER as well as a BIG MONEY SAVER. If you want berries for home use only order a smaller collection, but if you have no objection to making a BIG CASH PROFIT besides, plant this money making combination.

100 PREMIER

100 DR. BURRILL

$\$ 1.25$

100 GIBSON

100 PEARI

100 HARVEST KING

1.40

2.00

$\$ 6.55$

Special Price, Only \$5.85.

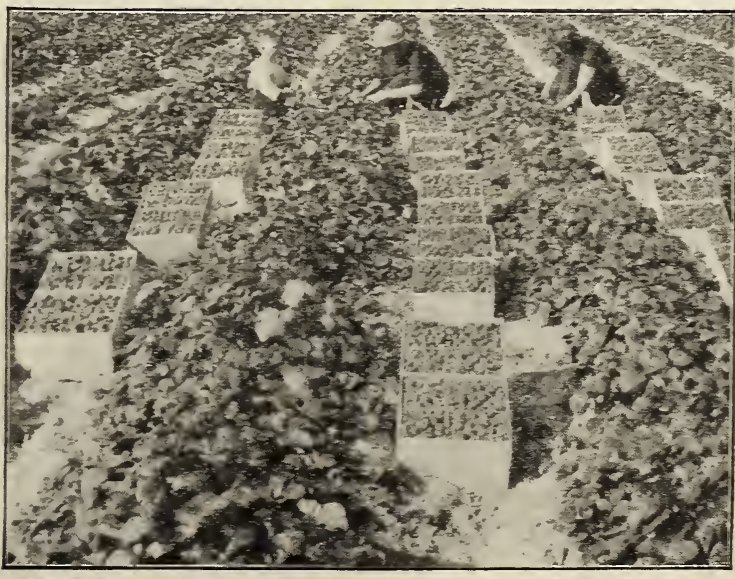




\section{This Year Plant One of Emlong's Turn Your Spare Time Into Cash!}

Plant an Emlong Demonstration block of Strawberries this Spring and see for yourself how easy and simple it is to make BIG MONEY in the berry business. A little of your spare time and a little of your idle land will convince you.

Berry prices are high and are bound to go higher. Fruit growers are indeed "sitting pretty" and are not worrying about the low prices of ordinary farm crops.

Why are berry prices high? Not because people are quitting the berry business, certainly-there is too much money in it to quit.

It's not because plants and trees are producing less than formerly, because EMLONG'S plants and trees produce heavier than any ever did before.

The secret of the whole thing is A BIG DEMAND. The demand for berries in the past few years has grown by leaps and bounds

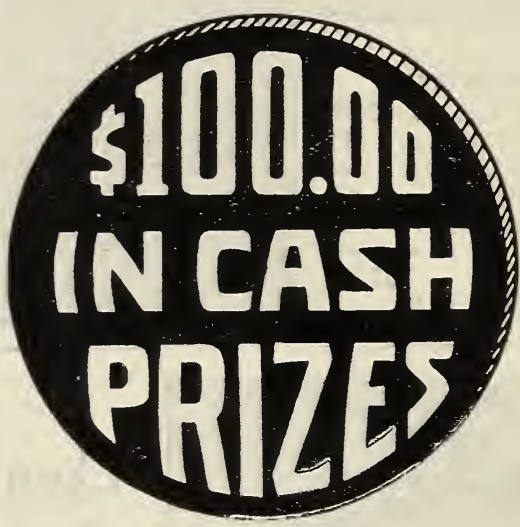

BIG PROFITS are there when you get them. Our careful growing, feeding and handling takes care of that. The special low priced demonstration blocks described and production has not kept pace with this tremendous demand.

More berries are needed and the big prices will continue. We know conditions and are giving you the "hot tip" when we tell you that berry growing is a sure-fire BIG, QUICK, EASY money making proposition.

Don't hesitate because you think the big prices will get too many folks started and cause an overproduction. Millions of people will never grow a berry because they are under the impression that it requires knowledge and wide experience.

We know and our customers know that ANYBODY can make BIG MONEY with EMLONG'S plants and trees because the BIG CROPS and on the next page are offered as an inducement to get more folks started in the berry business. There is room for a lot more, and a lot of money will be made. Will you get your share?

Strawberry money is quick money, and the biggest strawberry profits are made when you are able to supply your trade with fancy berries over a long season. The varieties we offer in our demonstration blocks make an ideal combination as they will produce continuously from extra early to extra late.

Order one of these demonstration blocks today. You can make all the way from $\$ 25.00$ to $\$ 50.00$ for every dollar you invest and can also win a cash prize amounting to more than the cost of the plants.

Previous experience is unnecessary. The BIG CROPS are in the plants, just give them ordinary care, and if you don't know how to do that ask for our booklet, "CORRECT CULTURE FOR SMALL FRUITS AND ORCHARDS", the simple instructions therein give you as much knowledge as the man with 50 years experience.

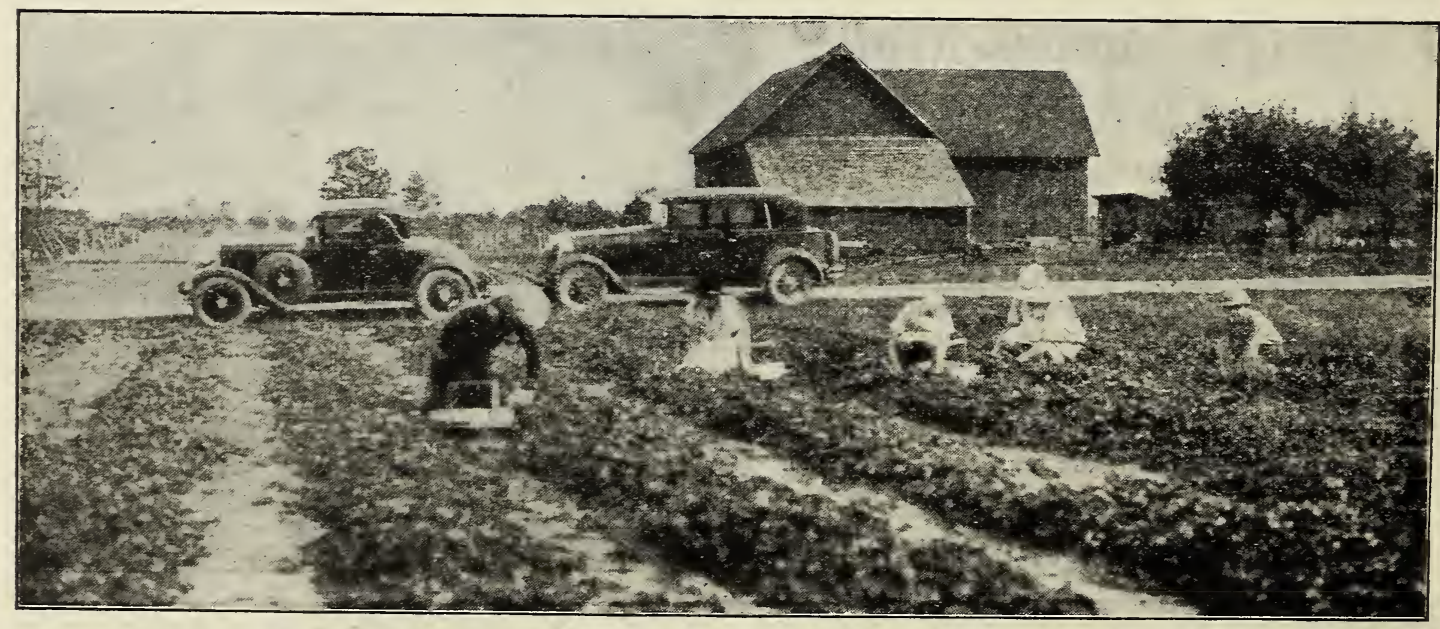

Strawberries will give the boys and girls something useful to do, and a cash income early in the season long before other crops Page Sixteen are ready to harvest. 


\section{ACRE DEMONSTRATION BLOCK}

In the Acre Demonstration Block you get 8000 plants. Season of ripening extra early to extra late, giving you an extra long and unbroken, fruiting season. The plants will be fresh dug and trimmed all ready for planting.

WHEN ORDERING JUST SAY

"ONE ACRE STRAWBERRIES"

4000 Premier (extra early) ...\$22.50 2000 Dr. Burrill (midseason) . . II.00 2000 Pearl (extra late) ...... I4.50

\section{Special Price, $\$ 43.50$}

CASH PRIZE, \$52.50. The person reporting the biggest yield from this acre block will receive our cash prize of $\$ 52.50$. Report must reach us before September Ist, I930.

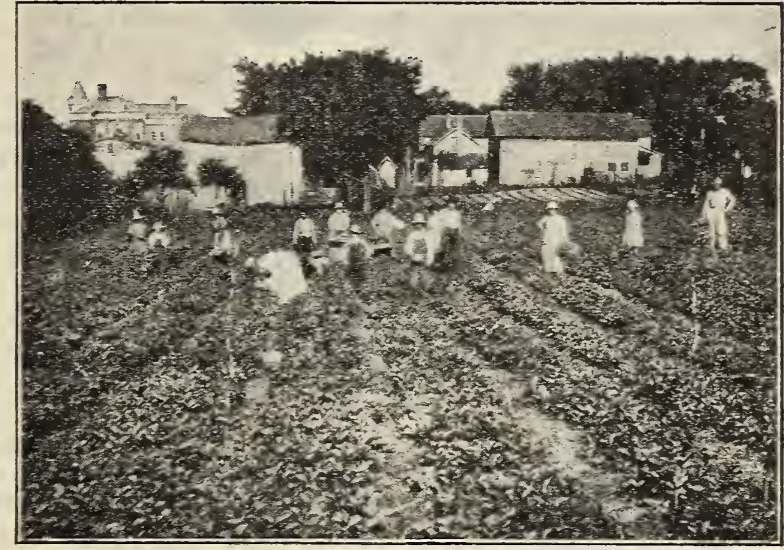

Cash Income of $\$ 785$ from One-Half Acre, Wm. Siefers, Iowa.

\section{HALF ACRE DEMONSTRATION BLOCK}

If you will plant this Half Acre Collection and give it half a chance you will know why EMLONG customers stay with us year after year and tell their friends to "trade" with us. A man soon learns where he can get his money's worth.

WHEN ORDERING JUST SAY

"HALF ACRE STRAWBERRIES" 2000 Premier (extra early) .....\$I2.50 I000 Dr. Burrill (midseason) ...... 5.75 Iooo Pearl (extra late) ........ $\quad 7.75$

\section{Special Price, $\$ 22.85$}

CASH PRIZE, \$32.50. The party reporting the biggest yield from the half acre block will receive our cash prize of $\$ 32.50$.

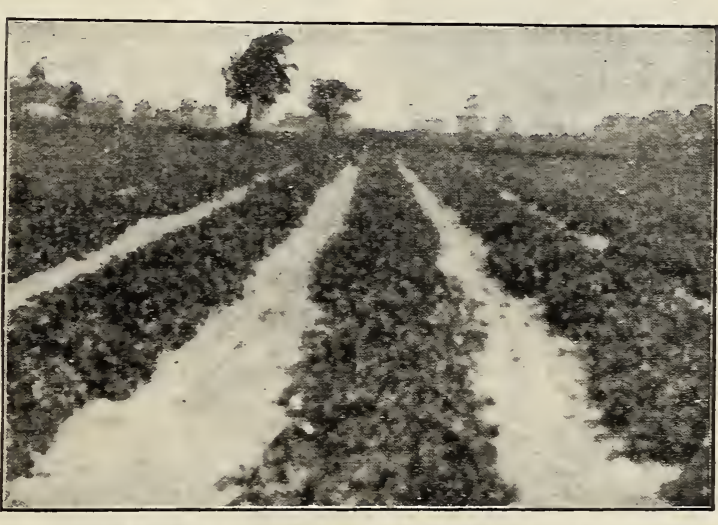

Profit of $\$ 1,200$ per Acre, Realized by E. E. Meese, of Ohio.

\section{QUARTER ACRE DEMONSTRATION BLOCK}

You want top prices and to get top prices you must have fancy berries. The "size" of your profits will be determined by the size of the demonstration block you plant. Your berries will all be fancy and you will get YOUR price.

WHEN ORDERING JUST SAY

"QUARTER ACRE STRAWBERRIES" Iooo Premier (extra early) .......\$ 6.75 500 Dr. Burrill (midseason) ........ 3.00 500 Pearl (extra late) ............ 4.00

\section{Special Price, $\$ 12.50$}

CASH PRIZE, \$I5.00. The person reporting the biggest yield from the quarter acre block will receive our cash prize of $\$$ I5.00.

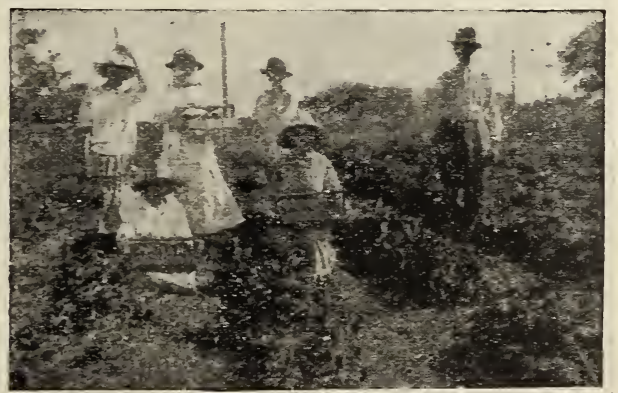

2,500 Quarts of Fancy Berries Reported by Minnesota Customers from Less than One-Quarter Acre. 

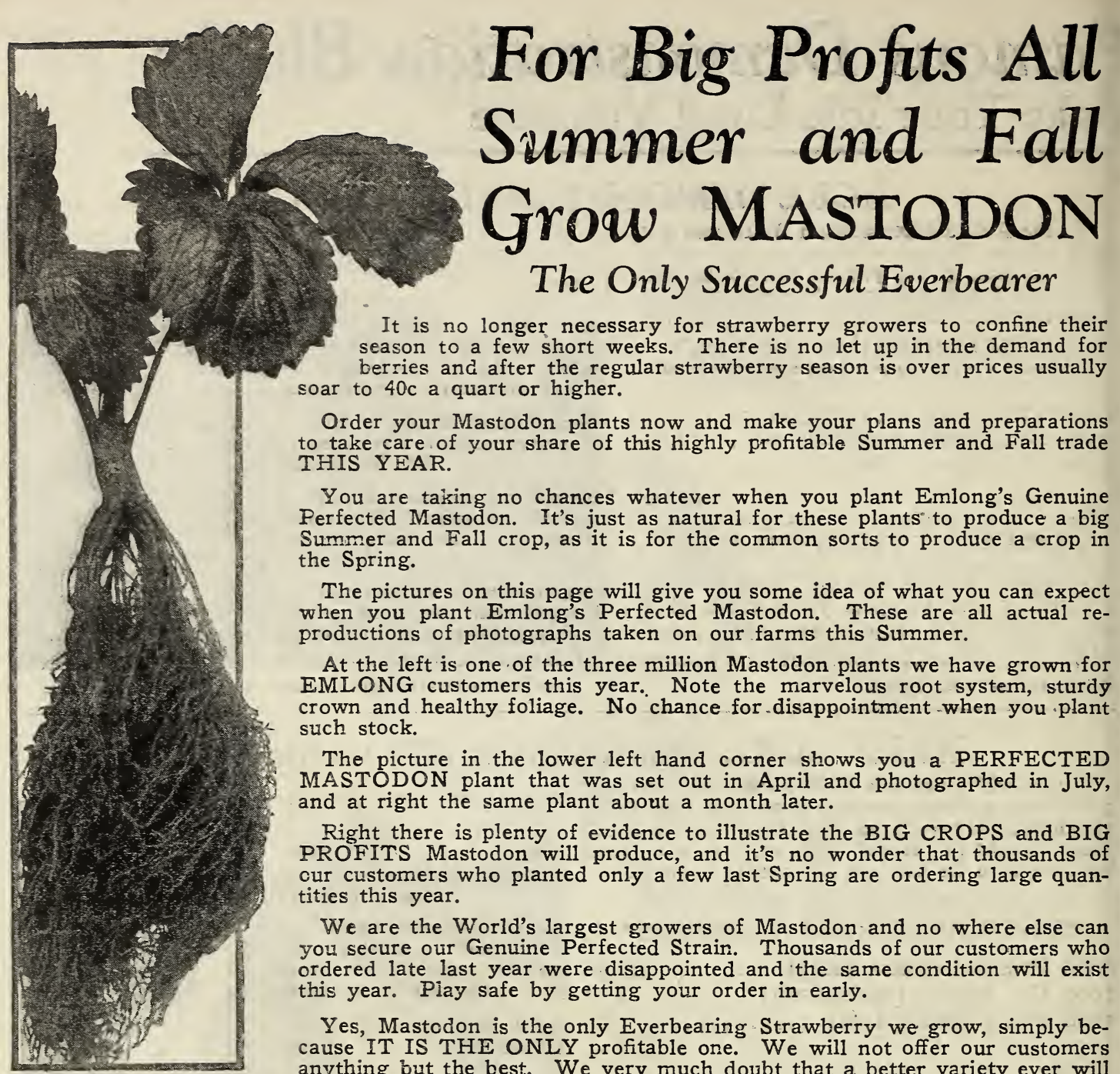

It is no longer necessary for strawberry growers to confine their season to a few short weeks. There is no let up in the demand for berries and after the regular strawberry season is over prices usually soar to $40 \mathrm{c}$ a quart or higher.

Order your Mastodon plants now and make your plans and preparations to take care of your share of this highly profitable Summer and Fall trade THIS YEAR.

You are taking no chances whatever when you plant Emlong's Genuine Perfected Mastodon. It's just as natural for these plants to produce a big Summer and Fall crop, as it is for the common sorts to produce a crop in the Spring.

The pictures on this page will give you some idea of what you can expect when you plant Emlong's Perfected Mastodon. These are all actual reproductions of photographs taken on our farms this Summer.

At the left is one of the three million Mastodon plants we have grown for EMLONG customers this year. Note the marvelous root system, sturdy crown and healthy foliage. No chance for disappointment -when you plant such stock.

The picture in the lower left hand corner shows you a PERFECTED MASTODON plant that was set out in April and photographed in July, and at right the same plant about a month later.

Right there is plenty of evidence to illustrate the BIG CROPS and BIG PROFITS Mastodon will produce, and it's no wonder that thousands of cur customers who planted only a few last Spring are ordering large quantities this year.

We are the World's largest growers of Mastodon and no where else can you secure our Genuine Perfected Strain. Thousands of our customers who ordered late last year were disappointed and the same condition will exist this year. Play safe by getting your order in early.

Yes, Mastodon is the only Everbearing Strawberry we grow, simply because IT IS THE ONLY profitable one. We will not offer our customers anything but the best. We very much doubt that a better variety ever will be found, but if it is you can be sure that we will have it.

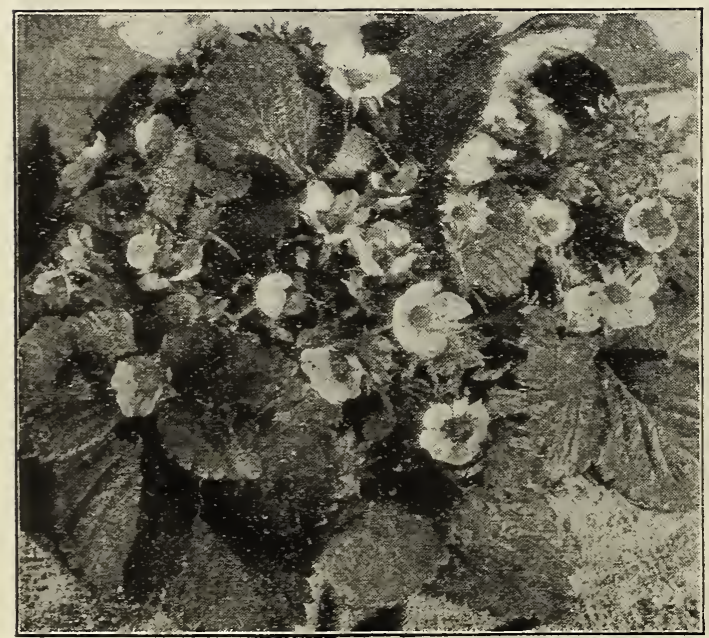

Fuil Bloom in July.

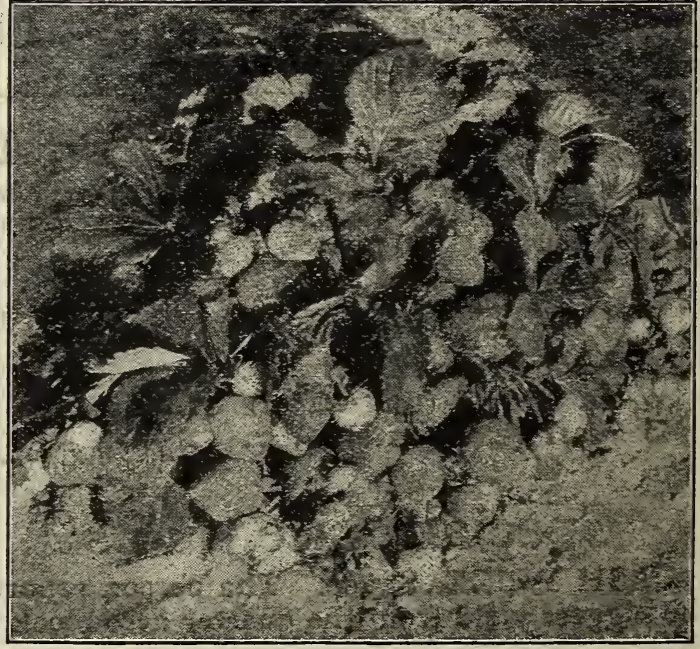

Loads of Berries Till Winter. 
To Assure Complete Satisfaction Plant Our Genuine Perfected Strain

\section{By Our Careful Methods of Selection and Breeding All Drones and Unproductive Plants Have Been Eliminated}

When you plant our Genuine Perfected Strain of this marvelous Everbearing variety you will have the satisfaction of knowing that you have made the right start.

Visitors to our farms, and there are hundreds of them every season, tell us that our Mastodon IS the most productive, healthy and vigorous they have ever seen.

The knowledge gained in more than 55 years' experience has been applied to the development of this great variety in our trial beds and propagating fields and we know, visitors know and our customers know that Emlong's Mastodons are as near PERFECTION as they possibly can be made.

Whether you order 100 plants or 10,000 you are going to get just that many true-to-type, true-to-name, productive plants and NOT a large percentage of weak, worthless, unproductive "soldiers."

Emlong's Perfected Mastodon comes to you ready to bear. They should commence in August and continue till winter. Not just a few berries to look at and admire, but literally loads of Big, Red Delicious Beauties, more than a quart per plant the first season.

\section{Read What These Men Say About Them:}

Prof. C. A. Boyer, Michigan Dept. Agriculture: "I am convinced that you folks have at last developed a profitable commercial everbearer. Your plants are large, sturdy, vigorous and unusually productive.

P. H. Dempers of the Rural New Yorker, inspecting our fields in September, remarked: "This is the greatest sight I ever saw, it is impossible to It will revolutionize the strawberry industry."

A. J. Miller, Ft. Madison, Ia.: "In $m y$ opinion your Perfected Mastodon is the greatest achievement ever known in strawberries."

Alexander Nursery co., Alexander, Minn.: When you say that your Mastodons are Genuine and Perfected, I believe you and know they are better, in fact I have found them to be superior to others.'

It will pay you big to plant our Perfected strain, "Every Plant Bears."

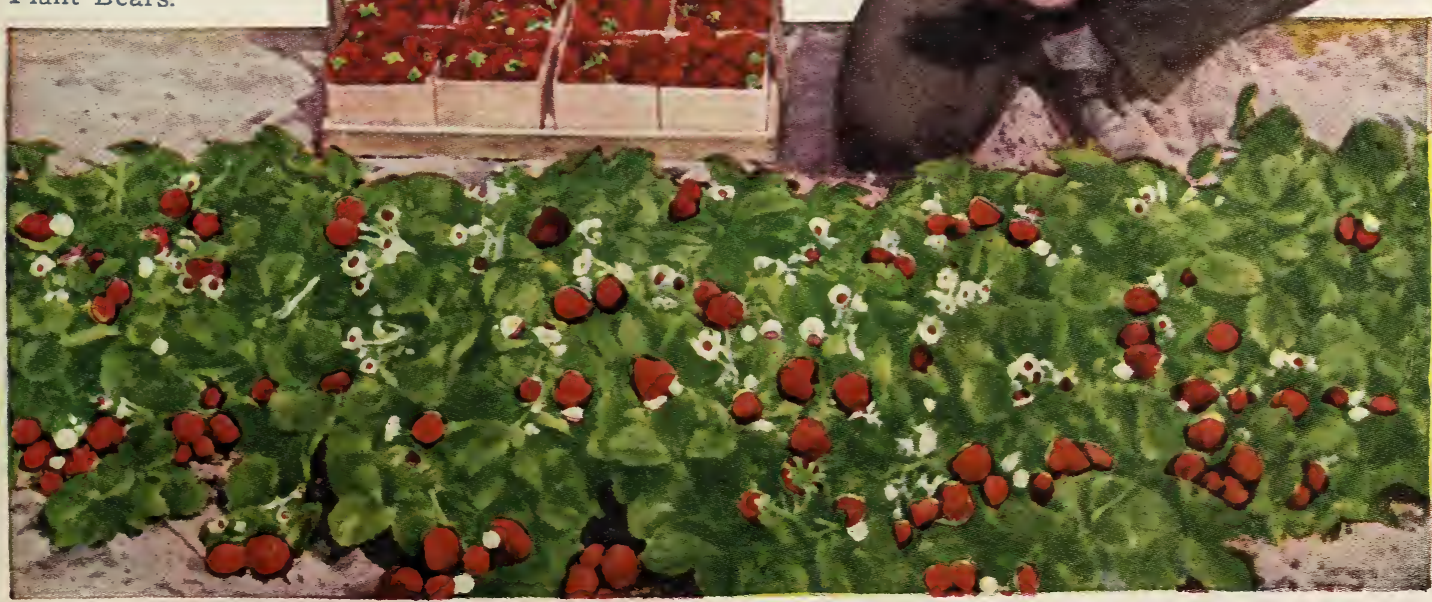




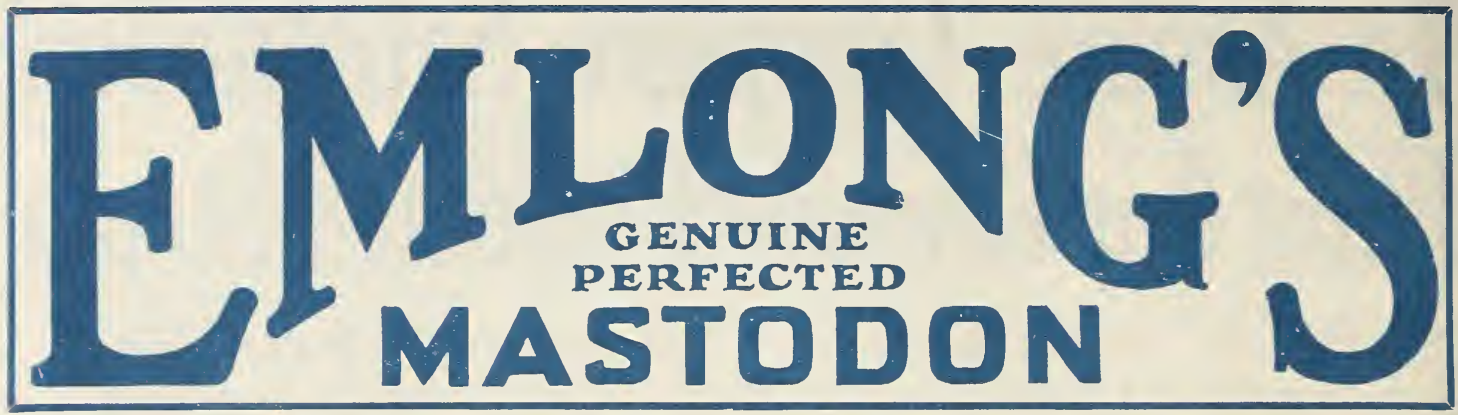

\section{Pays You Big in Pleasure and Profit}

If our Perfected Mastodons were only half as good as they really are it would still be the berry for you to plant.

Succeeds everywhere. East, West, North or South. Produces big crops regardless of soil and climatic conditions.

Frost proof, drouth proof. It is a perpetual bloomer and will produce a big crop in spite of frost or dry spells.

A vigorous grower. Easiest of all strawberries to grow. A strong sturdy plant with long moisture gathering roots.

Makes three acres out of one. Mastodon gives you three crops of berries within fifteen months after planting.

Set the plants in April or May and you will commence picking berries in August or September and continue till winter.
A great June variety. You get the second crop of berries next spring during the regular strawberry season.

Then another fall crop. After a few weeks' rest the same plants will give you the second fall crop.

Don't wait a year for berries, plant our Perfected Mastodon this spring and have berries all summer and fall.

Big in size and yield. Single berries measure $5 \frac{1}{2}$ inches around. 18 to 35 fill a quart box.

Delicious and attractive. One of the finest looking berries you have ever seen. Good to eat and good to sell.

A tremendous producer. Single plants have produced 322 berries during a single season by actual count.

Order your plants today. Grow this grand berry yourself and you can have genuine and absolute strawberry satisfaction.

Why be satisfied with "just as good." Plant our perfected strain and you will have the heaviest yielding strain of this great variety. 


\section{Have STRAWBERRIESthisFALL}

join ${ }^{i n}$ MASTIODON
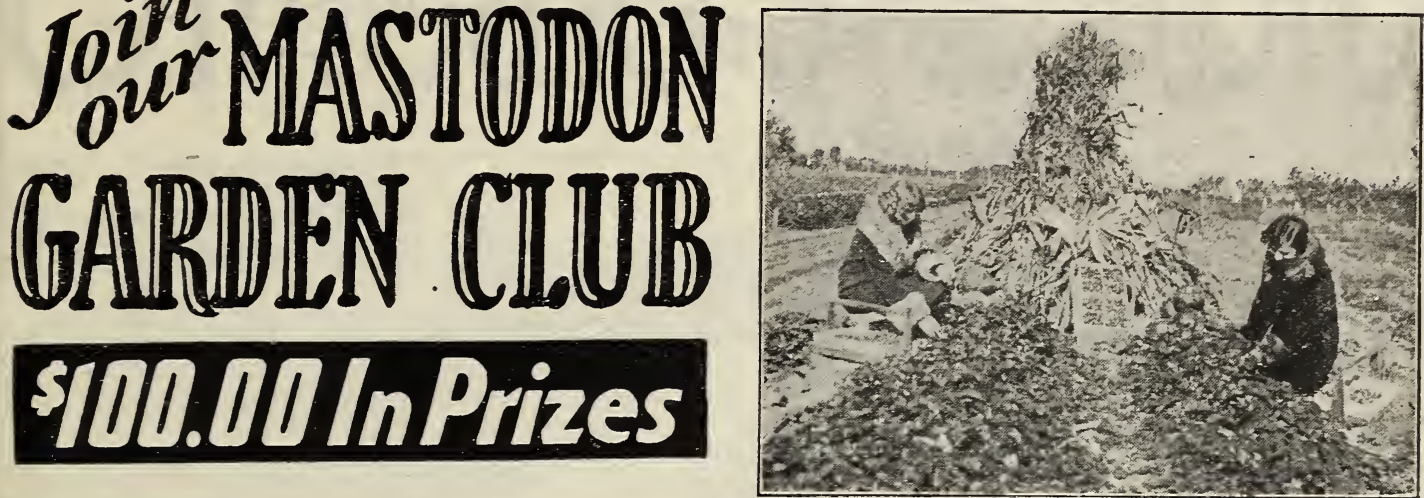

262 quarts of fine fruit is what 200 of our Genuine Perfected Mastodon plants gave Thomas King of Vancouver, Wash., up to October first. Pretty good record, isn't it, with better than half of the season still to go, and then two more crops of big berries next year.

Emlong's Mastodon are not partial. They will work just as hard for you as they did for Mr. King. Join our Mastodon Garden Club now and see for yourself how easy and pleasant it is to produce.big crops of big berries Spring, Summer and Fall.

We are going to give $\$ 100.00$ in prizes to the folks planting this garden this year. You are taking no chances as you have three ways of making money-berries to eat-berries to sell-and a chance to win one of three big cash prizes.

This prize money will be distributed as follows: $\$ 50.00$ first prize; $\$ 30.00$ second prize; $\$ 20.00$ third prize. To compete simply order the Mastodon

\section{Perfected ReadytoBear Mastodon Plants, \$4.65}

When ordering just say Mastodon Garden Club. The 200 plants will be reserved for you and shipped at proper planting time. You will not only have the satisfaction of having plenty of berries this Summer and Fall but a chance of winning a big cash prize. See what you can do.
Garden Club, keep a record of the number of quarts the 200 plants produce before October I 5 th, mail report to us not later than October 20, I929.

\section{Here Are Last Year's Prize Winners}

\section{FIRST PRIZE, $\$ 50.00$}

Vancouver, Wash., Oct. 15, 1928

The 200 Mastodon plants arrived in fine shape, and I had ripe strawberries in just 41 days after planting. They are the largest, finest berries I ever had. I have picked 262 quarts from them up to October 1 st.

THOMAS KING.

\section{SECOND PRIZE, $\$ 30.00$}

Tobinsport, Ind., Oct. 20, 1928.

Joined your Mastodơn Garden Club last Spring and have picked 213 quarts Your Mastodon are the best in the world. Vines are still loaded with berries after three hard frosts and I am still picking. JOSEPH SCHROADER.

\section{THIRD PRIZE, $\$ 20.00$}

Zillah, Iowa, Sept. 29, 1928.

I picked 312 pint boxes of beautiful berries from my Mastodon garden collection. We picked the first berries July 10th, and have had them every day since. My neighbors will all want some of your plants.

GEORGE LITTLE.

There is no reason why you cannot do just as well as these men have. Maybe you can do better. Either way you will be more than pleased. Order today.

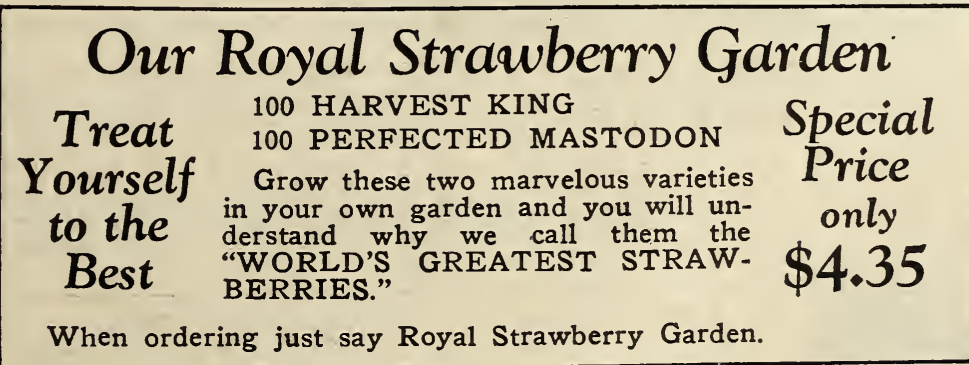




\section{G}

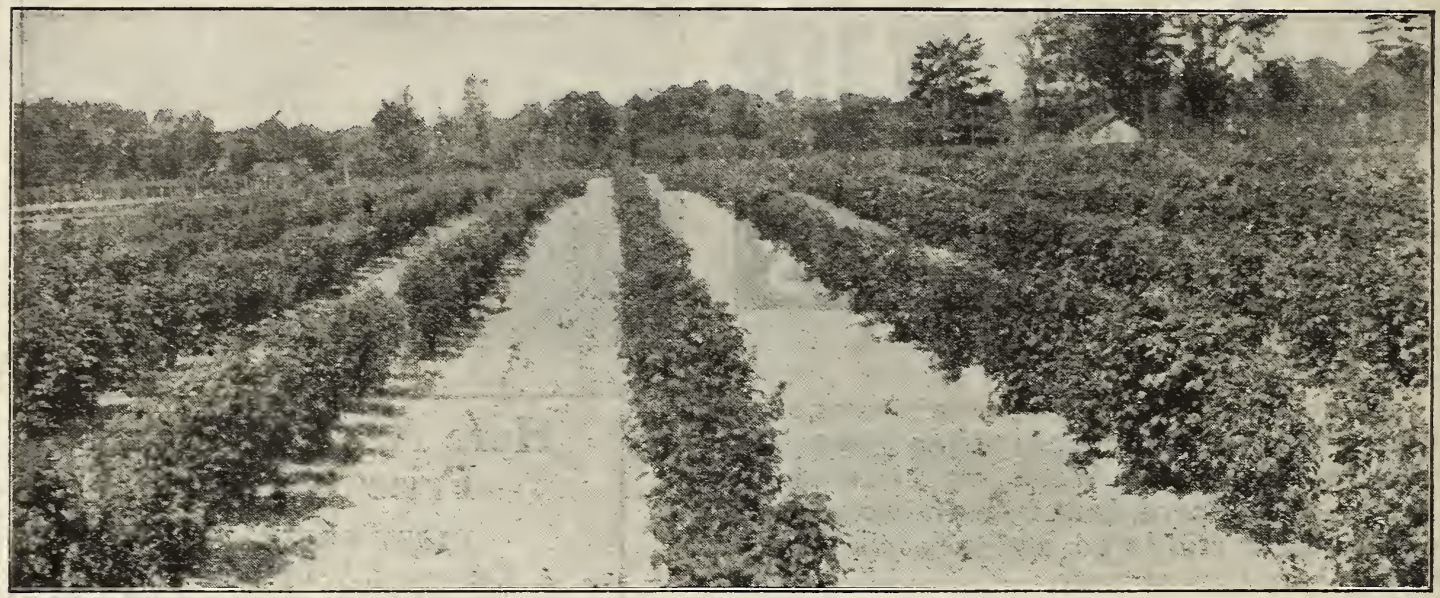

Eere is a patch of 1500 of EMLONG'S Mosaic Free Latham planted last Spring by Don Rogers of New York. Note the even growth, not a single plant missing.

\section{$\$ 3,200.00$ FROM 3 ACRES}

W. C. Webster, a prominent fruit grower of La Crescent, Minnesota, sold $33,200.00$ worth of Raspberries from a hree-acre field in just one year.
$\$ 630.00$ FROM $1 / 2$ ACRE

That is the report from our good customer, Mr. E. M. Buckley, Summerton, Mo. His are part Reds and part Blacks and only two years old.
$\$ 98.00$ FROM 400 PLANTS

$\$ 98.00$ cash and a big supply for home use the first year is the way our plants "behaved" for Mrs. D. L. Douglas of Greybull, Montana.

These folks were successful because they started right. Thousands of EMLONG customers are doing just as well as these folks have. It is not because they are "lucky," have better soil, or know more

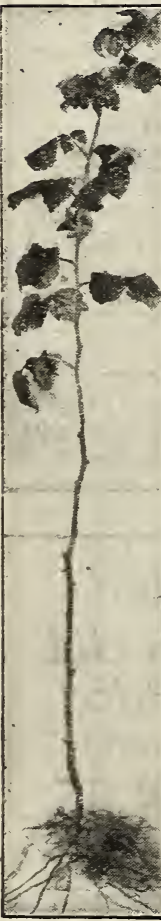
than other folks, they simply used good judgment and

\section{We Are the World's Largest} Growers of Raspberry Plants

The big demand for Emlong's Famous Double-Life Raspberry plants has made us the world's largest growers of this class of stock. If you will call on us any time during the Summer we can show you all the way from 50 to 75 acres of Red and Black Raspberries on our own farms. These are all grown for plants only and you can readily see why this young, healthy, thrifty stock is so vastly superior to plants that are dug from old diseased fruiting fields.

They Grow Fast It is not unusual for an Emlong and Bear Young Raspberry plant to produce berries The same season they are planted. start them growing and keep them growing. They are grown right, dug right and packed right. You get all of the roots and all of the life and plain common sense will tell you that such stock will make a bigger, quicker and better growth than stock that is at least half dead when you get it.

Disease Free A good healthy Raspberry plant should Double Life longer. But why is it that some berry bushes produce fair crops for two or three years and then turn a sickly yellow and dry up? Disease is the answer, and diseased stock is the cause of more than $95 \%$ of the failures in the fruit business. Absolutely healthy, triple-inspected stock is just another reason why Emlong customers succeed. as though they are good for that many more."

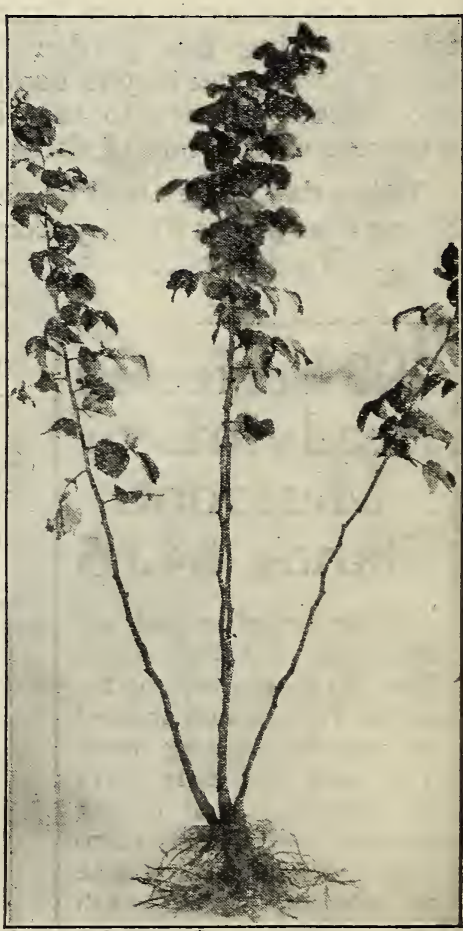

At the left is one of our straight, healthy Raspberry plants and here is the same plant 5 months later. 


\section{Plant Latham for Pleasure and Profit}

Latham has not only proven itself one of the greatest Red Raspberries in popular favor today, but the Greatest Red Raspberry of All Time. Wherever Raspberries have ever been grown Latham will thrive and produce abundantly, and what is more important it will do the same in those localities where it has been impossible to grow this profitable and desirable fruit successfully.

\section{A Phenomenal Producer}

No other variety of Red or Black Raspberry we have ever had could approach anywhere near Latham in productiveness, and until you see for yourself the massed clusters of extra large berries the canes support you cannot know what a tremendous yielder it really is.

A three-year-old test plot of Latham, grown with several other leading varieties, produced at the rate of 10,860 pint boxes of berries, while the next best variety produced. only 7,296 pint boxes. Latham out-yielded the next best variety over $30 \%$, and some of the others more than $100 \%$.

\section{Practically Everbearing}

Hundreds of our customers have written us remarking about the "many", "big", and "beautiful" berries our Latham plants have produced for them the Summer the plants were set out, and while we have never referred to Latham as an Everbearing variety it could rightfully be called such, and you will agree to this if you plant our Mosaic Free Latham this Spring because you will have berries this Fall.

\section{Long Profitable Fruiting Season}

Latham has a longer fruiting season than any other Raspberry. E. O. Schoembs, Villa Ridge, I11., says, "We began picking Latham June 10 th, and sold the last crate August 13th, but there were still good berries on the vines until late in the Fall."

Any berry that will give you a picking season from the tenth of June to the thirteenth of August is a money maker that you cannot afford to overlook.

\section{The Berries are Extra Large}

Latham berries as "big as a quarter" is no exaggeration. We have seen many of them an inch or more in diameter, and in spite of this exceptional size they will cling to the stem for days after they are fully ripe, which is a commendable feature as many of the Reds will drop to the ground even before they are ripe.

\section{Quality and Flavor Excellent}

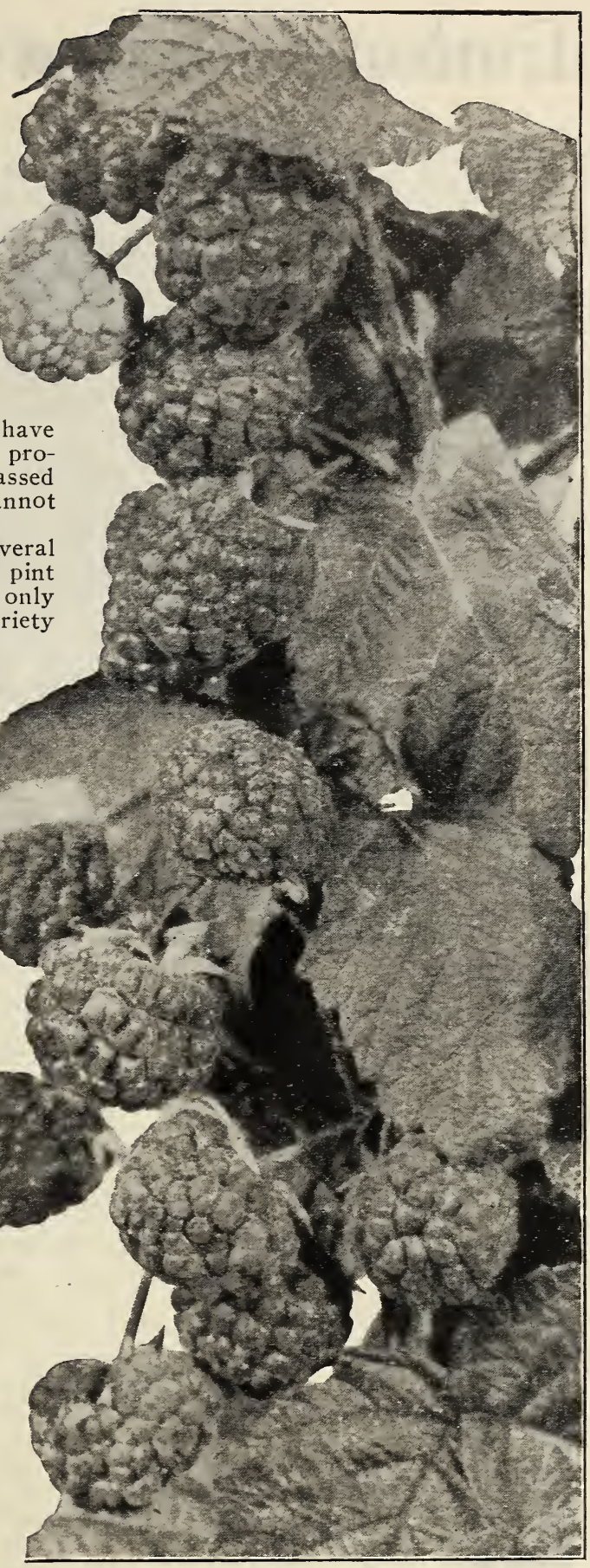

In quality, flavor, color and appearance, this great variety leaves nothing to be desired. A great table berry, a great shipping berry, a great canning berry and a great marketing berry. The extra large, first quality, fine colored Latham will command a premium of at least a dollar a crate over other varieties on any market.

\section{Easy to Grow and Extremely Hardy}

Due to the exceptional vigor and vitality of this variety it is one of the easiest of all varieties to grow. Plant our Double-Life Disease-Free Latham plants on any ordinary soil and you will be both surprised and amazed by the growth they will make in only a few weeks' time. They commence to bear soon and continue for many years. Emlong's Latham will produce more berries for less work than anything else you can plant. 


\section{Emlong's Extra Select Raspberries}

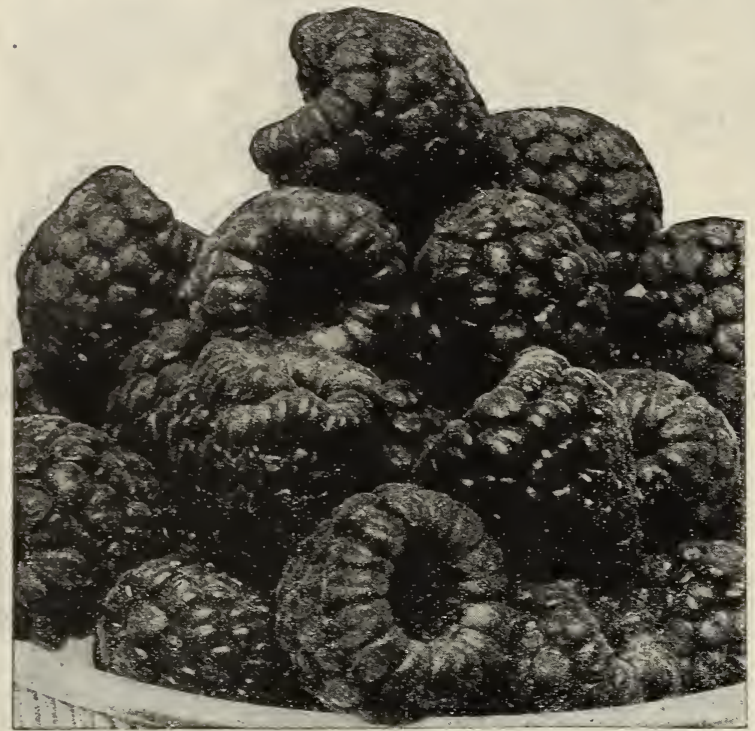

ictory Raspberries.

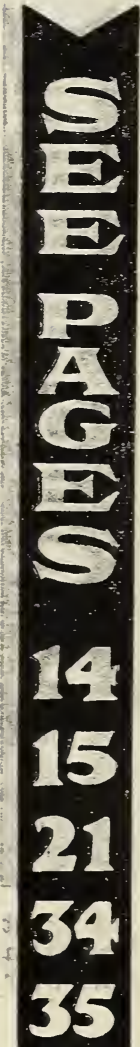

\section{How to Grow Red Raspberries}

One planting of Emlong's Double-Life Disease-Free Raspberry plants will give you big crops of fine fruit for many years. The kind of soil you have does not matter; if it will produce ordinary farm crops, it will be suitable for Raspberries. Prepare it just as you would for your garden or farm crops. For field culture Red Raspberries should be planted 3 feet apart in the row with the rows 7 feet apart. This requires about 2000 plants per acre. For garden culture they may be planted closer. In planting you may plow a furrow or dig the holes 6 inches square and 6 inches deep. Place the plant in the hole or furrow, spread the roots, then fill the hole, pressing the soil down firmly with the feet. After planting cut off the old stalk an inch or two above the ground.

The following Spring while still dormant, cut back the canes to a height of 3 feet and branches to a length of 6 or 8 inches.

When the fruiting season is over remove all old fruiting canes and burn them. This will destroy insects and give the new wood a better chance.

Confine the growth to 6 or 7 good strong canes to each hill, cutting off all other shoots or suckers as fast as they appear. Cultivate and hoe shallow.
EMLONG'S Victory is a variety that Victory seems to po'ssess every requirement that a profitable commercial Raspberry should have. Everywhere it is proving both popular and profitable. In productiveness, size, quality, flavor and appearance Victory is in a class by itself, and no matter what your soil and weather conditions are you can safely plant this variety with every assurance of success. Victory originated in Northern Michigan and has withstood 30 degress below zero without injury to a tip of a cane. The original bush was found in a field of Cuthbert, and Victory has some of the characteristics of that grand old variety.

see page 52 .

The canes of Victory are very strong and vigorous, well able to carry the tremendous loads of fruit produced. The originator claims this variety has never been affected with anthracnose, or disease of any kind. It is undoubtedly the greatest producer of all-Red Raspberries, a single bush having made the record yield of 19 pints of berries in one season. Berries are extra large, a beautiful dark red, firm, sweet, and of delicious flavor. Quality of the best, its firmness guaranteeing perfect shipping qualities. We have a fine stock of genuine, healthy Victory plants. For prices see page 52 .

\section{EMLONG'S Cuthbert}

This grand old reliable variety has made more money for fruit growers than any other Raspberry. Cuthbert has long been considered the standard of excellence on nearly every fruit market in the United States. Whether you are planting Raspberries for home use or market you will make no mistake in selecting Cuthbert. The canes and foliage are perfectly healthy in every way. It is a tall, vigorous grower and very productive, one of our customers reporting a yield of 1240 24-pint cases from a four-acre plantation. Fruit is large, well colored, flavor and quality of the best. A good variety for fresh table use, canning or shipping. For prices see page 52 .

\section{SUCCESS AT LAST}

I wish to thank you for the large healthy Raspberry and Blackberry plants you sent me last Spring. During the past several years I have ordered plants from a dozen different nurseries and your plants are the first I have got to grow. Every one of your plants made a wonderful growth and what is more I picked a number of berries from these young plants. I expect to grow all the berries we will need from now on.

H. B. Cunningham, O’Neal, Ark.

\section{COLLCTIONS ForYour GARD WN}




\section{Our Name is Your Guarantee}

\section{EMLONG'S \\ Early King}

King is without exception the most profitable early Red Raspberry ever grown. In this locality, which no doubt is the greatest Raspberry producing center in the world, Early King has long been the main crop variety, and often nets as much as $\$ 1,000.00$ per acre each season.

Perhaps the greatest outstanding feature of this variety is its earliness. The first berries usually ripen about July first, and due to its wonderful productive ability it continues fruiting heavily for four to six weeks. The berries are borne in clusters the entire length of the bush and time after time I have seen rows only 100 feet long produce 48 pints of fine fruit at a single picking.

The berries are large, firm, beautiful and easily picked as they ripen all over at once. King thrives equally well on light or heavy soil and is perfectly hardy. It will produce its customary big load of fruit East, West, North or South. Plant Early King for either home use or market and you will have some of the finest of all Red Raspebrries. For prices see page 52 .

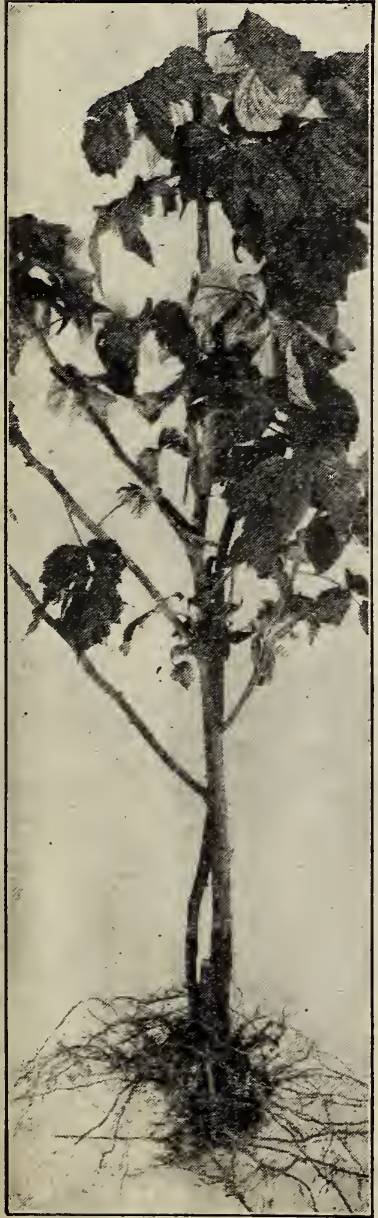

Red Raspberry Transplant.

\section{EMLONG'S St. Regis} other Fall-bearing variety. There is a big demand for this fine fruit in the late Summer and Fall, and many growers in this locality grow St. Regis for Chicago market and receive $\$ 8.00$, $\$ 10.00$ and even $\$ 12.00$ for 24-pint crates. However, if you do not grow them for market, by all means plant a few bushes for home use and enjoy this delicious fruit all Summer and Fall. St. Regis produces a big crop of fruit during the regular Raspberry season and then continues bearing all Summer and Fall on the new canes. St. Regis resembles King in manner of growth, ripens extra early and the fruit is similar in quality, flavor, and appearance. For prices see page 52 .

\section{Two-Year Transplanted Red Raspberry Plants}

In response to a demand from many of our customers for extra large stock that would give them quick returns, we have grown a limited supply of this transplanted bearing age stock. While these plants will produce fruit the first season, we recommend that they be cut off near the ground after planting as this will assure nearly a full crop of fruit the second year.

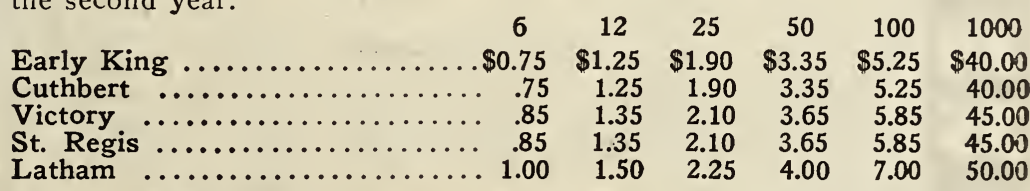

Fifty of Emlong's Double-Life Disease-Free Raspberry Plants Will Give Any Ordinary Family a Year Around Supply of. This Fine Fruit. 


\section{Emlong's Extra Select Raspberries}

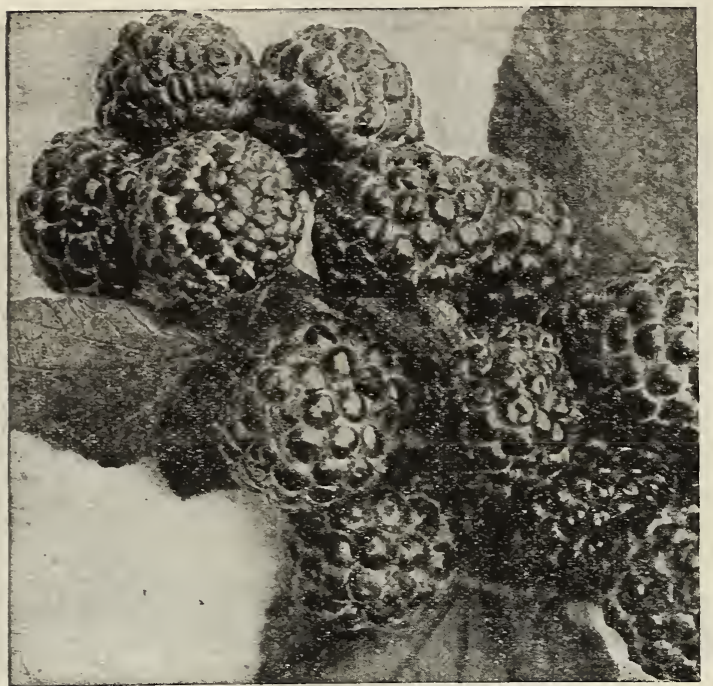

Cumberland Raspberries.

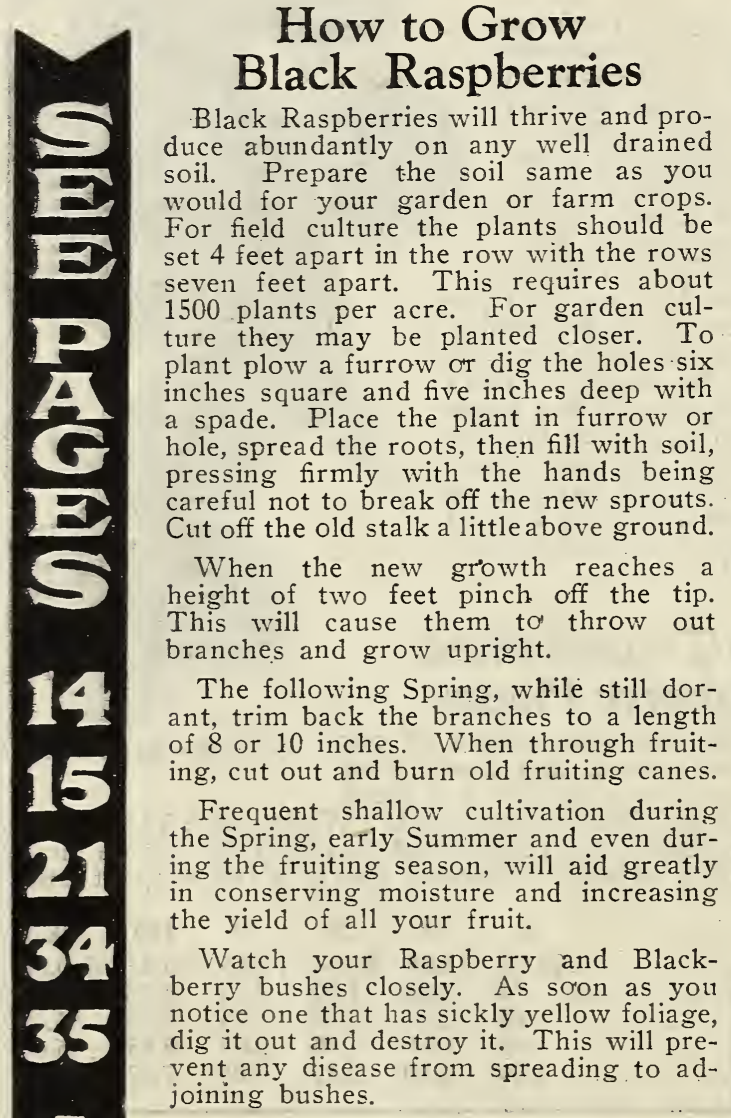

\section{EmLoness Cumberland}

Cumberland is without question the most po'pular and most profitable Black Raspberry ever grown. It is the one safe and reliable commercial variety, because you can depend on a big paying crop regularly. We call it the "BUSINESS BLACKCAP" because it succeeds everywhere-light or heavy soil-East, West, North or South, wherever Raspberries are grown, you will find Cumberland the leading Blackcap, and it never fails to produce its customary big crop every year.

We have never known Cumberland to fail. The demand for these plants becomes greater every year, and more Cumberland is planted than all other varieties combined. This variety is perfectly hardy and tremendously productive, the bushes are vigorous, upright, strong, and healthy. Berries are extra large, glossy black, not equalled by any other variety in quality, flavor and appearance. It's good to eat and good to sell. For prices see page 52 .

\section{EMLONG'S \\ Plum \\ Farmer}

Plum Farmer is very popular with many growers on account of its earliness, and ability to mature its customa.ry. big yield in a very. short time, usually 15 to 20 days. The plants are healthy, canes strong growers. Produces plenty of bearin $\mathrm{g}$ w o o d, which insures a heavy crop of fruit. The berries, which are produced in clusters, are large, well colored and of first quality. Plum Farmer will give satisfaction everywhere. Ripens a week earlier than Cumberland. For price see page 52 .

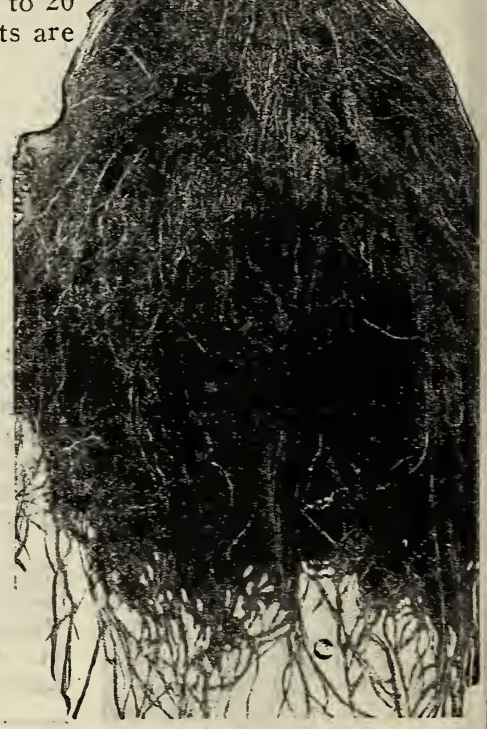




\section{Our Name is Your Guarantee}

EMLONG'S

\section{Honey Sweet}

This variety, which is one of the latest additions to the Raspberry family, is an ideal variety for ho'me use, as the flavor is the finest we have

ever found in any Blackcap-a peculiar, rich, alluring flavor-something that is impossible to describe and hard to forget; requires but very little sugar for table use, pies or canning, and for that reason is a very economical variety. The plants are exceptionally vigorous and productive. Berries are large, bluish black, quality of the best. Ripens with Cumberland. For prices see page 52.

\section{EMLONG'S}

\section{Winfield}

This variety is grown extensively in the South and West, and many growers claim it is superior to the old favorite Cumberland. In hardiness and productiveness it is excelled by no other variety. Never been known to winter-kill through fifteen years of fruiting, and stands extreme drought. The berries are enormous, single berries covering a quarter. Four to six great clusters are produced on each branch. Fruit is firm, sweet, rich and juicy. Bush is healthy and vigorous; canes strong and healthy, not troubled with rust. Get started with this valuable variety this year. For prices see page $\mathbf{5 2}$.

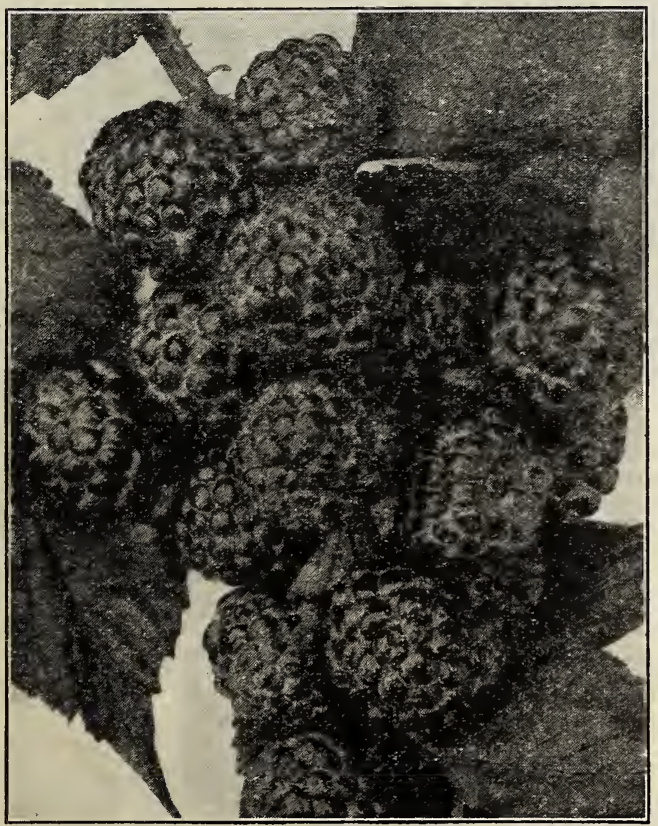

Kansas.

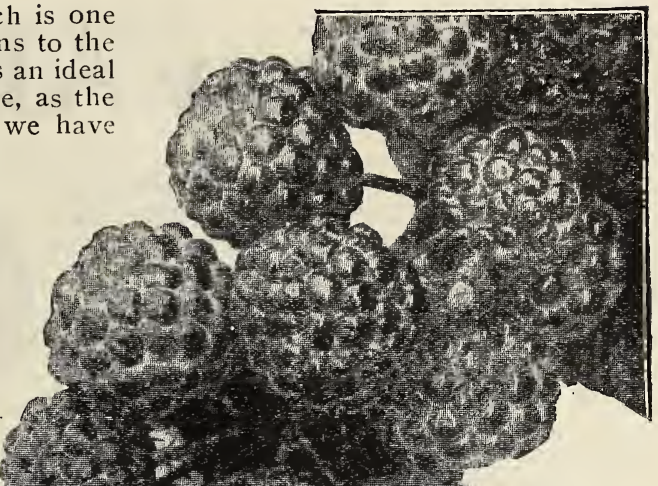

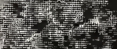

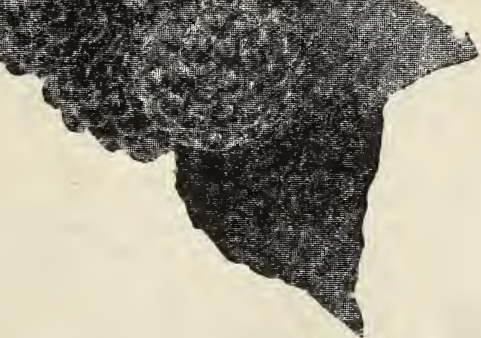

Honey Sweet.

\section{EMLONG'S Kansas}

This is the earliest of all Black Raspberries. A very strong grower and produces its crops of top quality fruit in a very short time. Berries medium size, firm, handsome and of the best quality. Kansas is perfectly hardy, drought resistant; in fact, a good all-purpose variety that will give both pleasure and profit. For prices see page 52.

\section{Two Year Transplanted Black Raspberries}

These are extra strong, heavity rooted plants that have been grown the second year in the nursery row. They save you a year's growth. While they should produce fruit the first year, we recommend that they be cut off near the ground after planting. This will assure an enormous growth and nearly a full crop of fruit the year following planting.

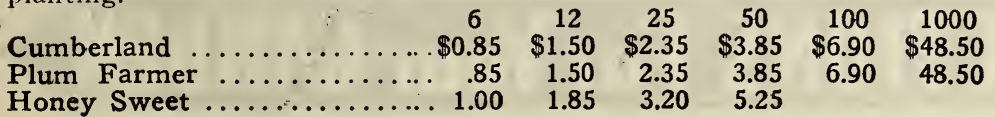

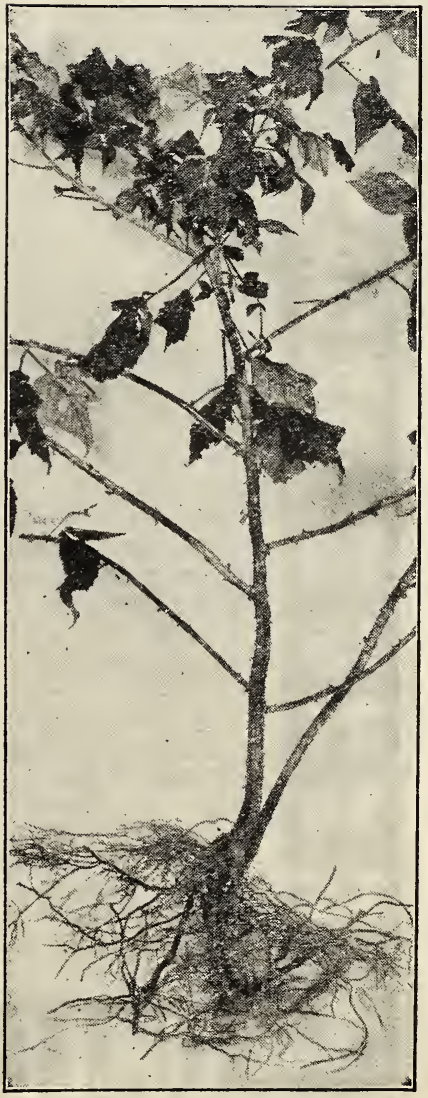

Llack Raspberry Transplant. 


\section{Emlong's Extra Select Blackberries}

\section{The New ALFRED}

Alfred has never failed to produce a big crop of fine fruit, and we are firmly convinced that it is one Blackberry that will replace all others and become a universally popular and profitable variety. Note the following good features of this splendid variety.

\section{A VIGOROUS GROWER. Alfred is} a vigorous grower, producing strong, well branched canes, well able to carry the tremendous crop of fruit produced.

PERFECTLY HARDY. Can be grown everywhere without Winter protection, having withstood 30 degrees below zero with not a tip of a branch injured.

VERY PRODUCTIVE. In yield of fruit Alfred cutclasses all other varieties, a single bush having produced the record-breaking crop of nine heaping quarts in a single season.

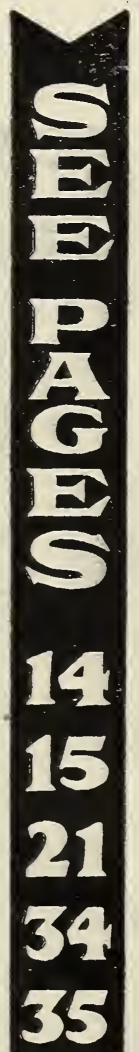

BEARS YOUNG. Alfred produces nearly a full crop of fruit the year following planting, and usually produces some fruit the year the plants are set.

RIPENS EARLY. The fruit commences to ripen a week earlier than other Blackberries, and continues over a very long season. It is not unusual to see ripe berries, green berries, red berries, and blossoms, all on the same bush.

IMMENSE SIZE. The large size and attractive appearance of the fruit is remarkable. Many of the berries measure three inches around and two inches in length. Color a glossy, jet black, very beautiful.

SWEET AND DELICIOUS. Alfred is the one ideal table variety because the fruit is seedless, coreless, sweet and delicious. Quality of the very best.

We have succeeded in growing a fairly large stock of Alfred plants this season, therefore, have greatly reduced the price, so that it is within the reach of all who wish to grow the latest and best Blackberry. For prices see page 52 .

\section{How to Grow Blackberries}

Blackberries are not partial as to soil or climatic conditions. If you can grow good garden or farm crops you can grow Blackberries. For field culture plant them 4 feet apart in the row with the rows 7 feet apart. This requires about 1500 plants per acre. Plow a furrow or make a hole with a spade 6 inches square and 5 inches deep. Place the plant in the hole or furrow, spread the roots, then fill with soil and press down firmly with the feet or hands. Cut off the old stalk a little above the ground. The next Spring cut back the new growth one-third, and after the fruiting season remove and destroy the old bearing wood. Cultivate and hoe shallow. 


\section{Our Name Is Your Guarantee}

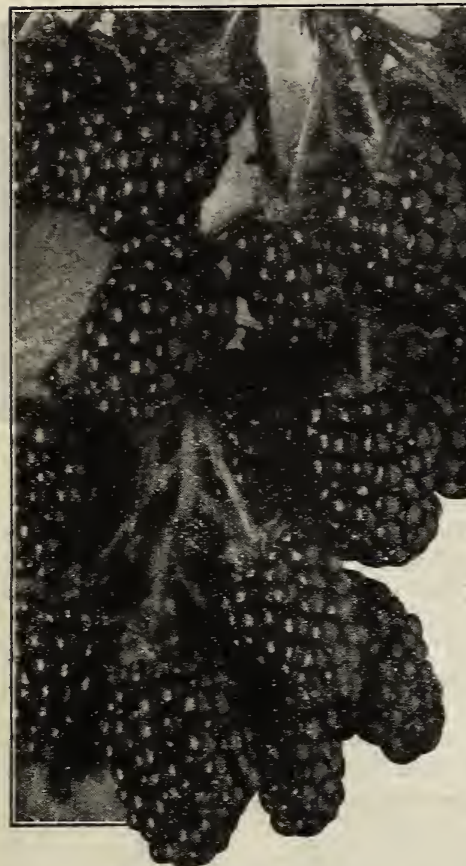

Eldorado Blackberries.

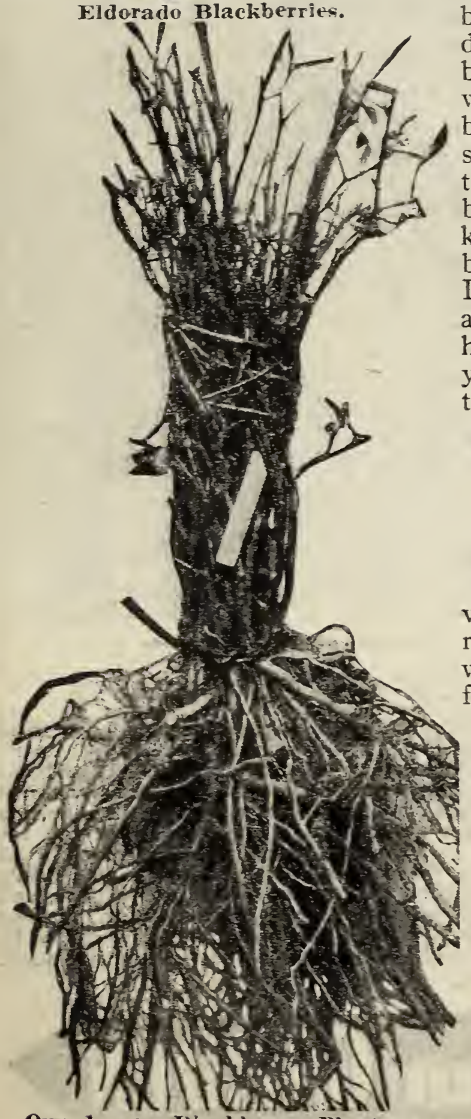

Our 1-year Blackberry Plants are well rooted.

\section{EMLONG'S Eldorado}

The cluster of berries at the left will give you an idea of the unisual productiveness of Emlong's Eldorado Blackberries. If you are looking for a profitable and dependable Blackberry you will not be disappointed in Eldorado because it produces a big crop of fine fruit regularly.

This extra fine Blackberry has long been considered the leading commercial sort and is also a desirable berry for home use as the berries are large, with very few seeds, jet black color and the flavor is sweet, melting and very pleasing to the taste. The quality is excellent as the berries will hold up well for several days after picking.

In health and vigor Eldorado is supreme. It is a strong upright grower and absolutely hardy, requiring no Winter protection in even the coldest climates.

You will make no mistake in planting Blackberries as there is a big demand for this fine fruit, ripening as it does when there is but very little other fruit on the market. Emlong's Eldorado and Alfred cover a very long fruiting season. Plant at least 25 of each for home use and you will have a generous supply of this fine fruit. For prices see page 52 .

\section{Lucretia Dewberries}

How they glisten when moist with dew-these long, mammoth, rich black berries-recognized by horticulturists everywhere as the leading variety-the king of the whole Dewberry tribe! Each plump berry is a morsel of delight. Incomparably better in every way than any blackberry you have ever seen or tasted. And the big prices they bring on the market! For real profit be sure to plant LUCRETIA. And also in your own home garden-for yourself and to sell to neighbors.

\section{RIPENS ABOUT TEN DAYS \\ BEFORE \\ ORDINARY \\ BLACKBERRIES \\ LUCRETIA is a \\ very early bearer, ripening from a week to ten days be-}

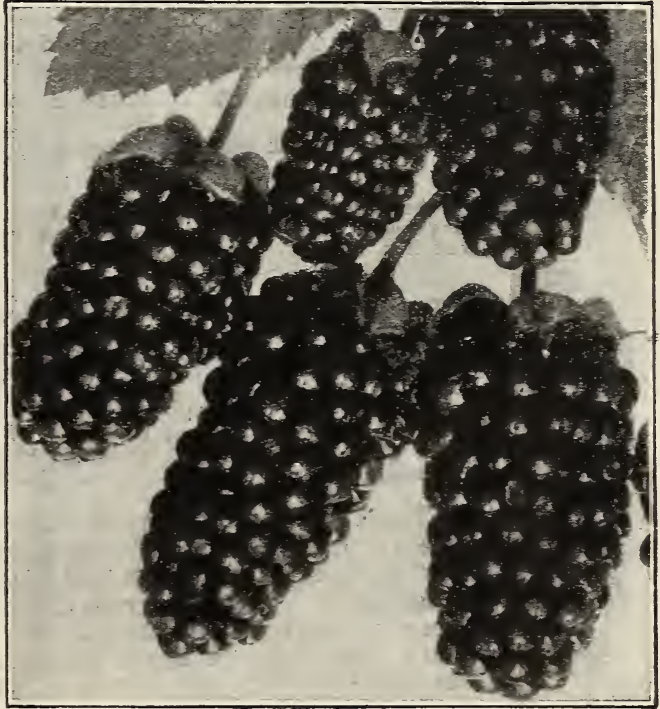

Lucretia Dewberry. fore even the earli-

est ordinary blackberries. This, together with the fact that they are unquestionably the finest looking berry of their kind and of such big uniform size, makes them topnotchers in price on any market. For prices see page 52.

\section{Two-Year Transplanted Blackberries}

For those wanting quick results we offer two-year transplanted stock in both Alfred and Eldorado. This stock will save you a year as they will come into full bearing a year ahead of one-year plants. Plants set out this Spring will produce berries this Summer but for best results we recommend cutting off the old stalk three inches above the ground. This will assure a big growth and nearly $\begin{array}{lllllll}\text { a full crop next season. } & 6 & 12 & 25 & 50 & 100 & 1000\end{array}$

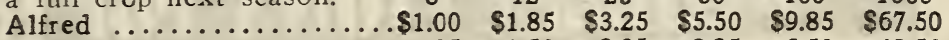
Eldorado $\ldots \ldots \ldots \ldots \ldots \ldots \ldots . . .65 \quad 1.50 \quad 2.35 \quad 3.85 \quad 6.50 \quad 48.50$ 


\section{Grow Big,Sweet, Juicy Grapes}

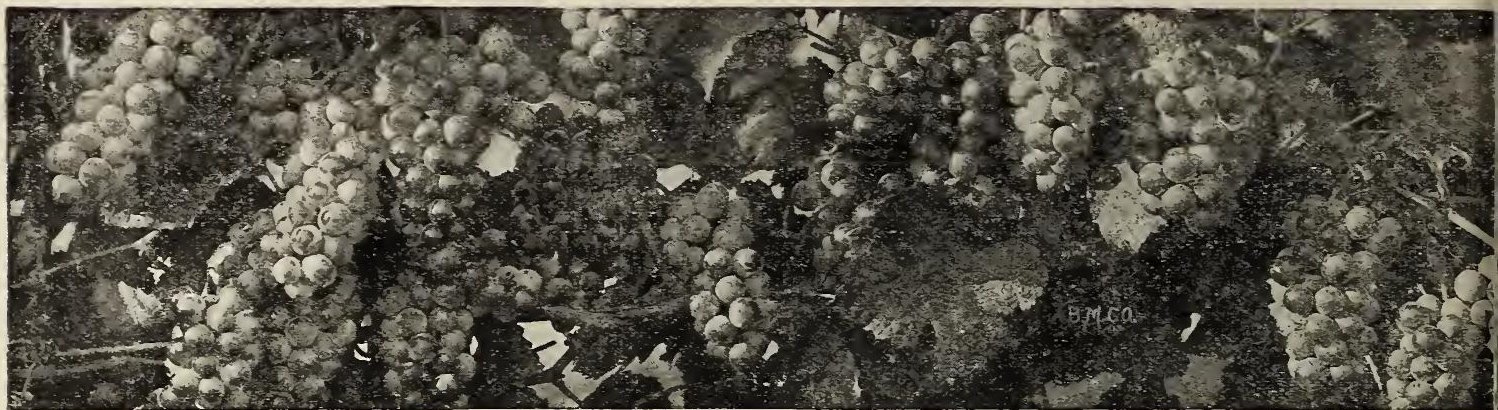

\section{You Can Have Them Just Like These}

Grapes are undoubtedly the easiest of all fruits to grow. They will thrive and produce abundantly everywhere with but very little attention. Even on the very poorest of soils, along a fence or in shady out-of-the-way places you will find it an easy matter to provide yourself lavishly with this extra choice juice-laden fruit.

We have long specialized in producing extra select grape vines and many of the largest and most profitable vineyards in the country have been started with our well rooted, heavy yielding, guaranteed true-to-name vines.

As a grape vineyard is a life time proposition you cannot afford to take chances with uncertain stock. You must rely entirely upon the ability and integrity of the men from whom you buy to supply you with true-to-name, heavy bearing stock.

We feel that we are justified in making the statement that we can furnish you with the finest grape vines it is possible to produce.

Here is what our customers say:

Leesport, $\mathrm{Pa}$ 11 4
4
4
2 "The grape plants I got from you three years ago have
done fine. They produced about three tons of fruit per acre last Fall." produced about three GEO. ETTEL.

Denver, Colo.

"I want to thank you for the fine plants I' received from you. Tvro other parties that got the grapes with me said they had never seen anything like them or half as said they had never seen anything like them or half a
P. K. MOORE.

Galion, Ohio.

"Every one of the grape vines we got of you last Spring made a wonderful growth. Many of them had fruit on this season."

There are a good many reasons why our plants are superior to those grown "any old way" by every Tom, Dick and Harry. Our soil is especially adapted to root growth which assures a perfectly balanced root system for every piant. (Note the root system of one of our vines, picture at bottom of page).

The propagating stock from which our plants are grown are taken from our own healthy, vigorous, heavy bearing vines and for that reason we can guarantee every plant to be a heavy producer and ABSOLUTELY true to name.

They are not only carefully grown. They are carefully dug, carefully handled and carefully packed. When you buy from Emlong's you get all of the roots and all of the life, and that is what you must have to grow successful crops.

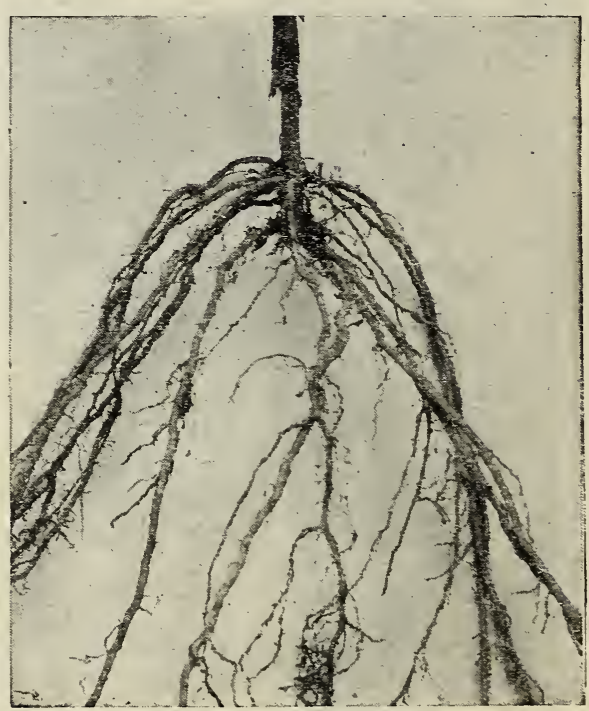

Roots of an Emlong Vine.

\section{HOW TO GROW GRAPES}

For field cuiture grape vines should be planted 8 feet apart in the row with the rows 10 feet apart. This requires about 450 vines per acre. For home use in arbors, etc., they can be planted 5 or 6 feet apart. Make a hole 12 inches square and 8 inches deep, place the plant in the hole (first cut the roots to 10 inches in length) spread roots in all directions, fill the hole and pack the soil firmily with the feet. Cut the top back to two buds, and when new growth appears break off all but one strong shoot. The following Spring this should be tied to a stake which will assure an upright stalk. 


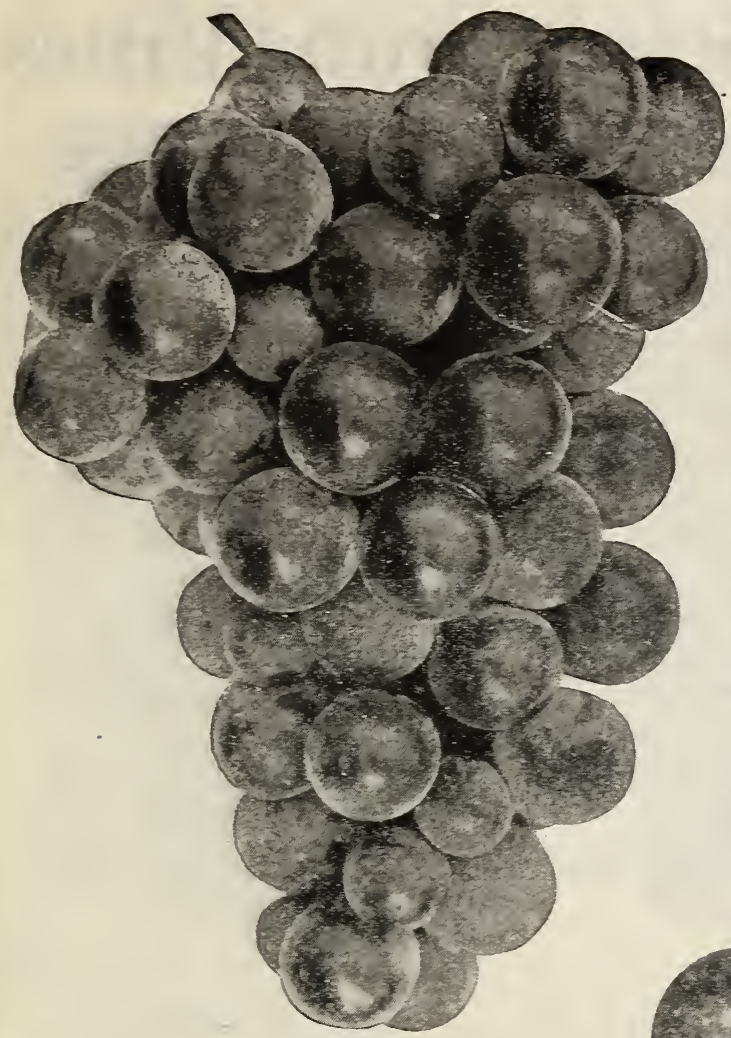

\section{The Great Table, Market and Wine Grape}

\section{Emlong's Concord}

In every section oi the country with the exception of the Pacific coast Coricord is the most popular Grape. Buyers everywhere pay a premium for this super-quality Grape as it is supreme for every purpose that this iruit is wanted. Concord is perfectly hardy, extremely productive and adaptable to all soils and climates. The bunches are large and compact, berries large, bluish black color, sweet and juicy, superb in quality and delicious in flavor.

The vines are strong and healthy; foliage tough and leathery, resistant to insects and diseases. Extremely hardy and a heavy annual bearer.

TWe have over forty acres planted exclusively to Concord and as the cuttings for our plaris are taken from the heaviest bearing vines in this vinevard we are able to provide our customers with the heaviest yielding plants it is possible to produce and every one will be $100 \%$ true to name.

Right now is the time to plant that vineyard ou have had in mind as we are offering our extra select vines at a price you cannot afford to over-

Concord Grapes.

RED, WHITE AND BLUE

COLLECTION, ONLY $\$ 1.00$

6 Concord Blue

2 Niagara White

2 Brighton Red

2 Campbell Early Blue

12 STRONG VINES, ONIY \$1.00

\section{Caco}

The Sensational New Red Grape.

(For size, shape and color, see page 37 ).

This is the new, quick growing. young bearing, early ripening, deliciously sweet big red Grape that has created sensations in nearly all of the large Grape growing centers of the country.

As a variety for home use leading Horticulturists and Experimental Stations claim it has no equal, and we will rouch for this, statement.

Caco has a peculiar characteristic not found in any other variety, in that it is so rich. meiting, sugary and excellent in fiavor that it can be eaten with rare enjoyment fully two weeks in advance of being fully ripe.

In appearance it is the most beautiful of all hardy grapes, possessing a rich wine red and amber coloring. The berries are unusually large; bunch large and compact.

The vines are very strong, perfectly hardy, vigorous growers, healthy and prolific. Ripening as it does early in September, the big crop of fruit is fully matured before danger of frost.

We have a limited supply of strong vines friced while they last as follows:

$\begin{array}{ccccccc}\text { Each } & 6 & 12 & 25 & 50 & 75 & 100 \\ 45 c & \$ 2.25 & \$ 4.00 & \$ 7.50 & \$ 14.00 & \$ 20.00 & \$ 26.50\end{array}$ 


\section{Emlong's Extra Select Grape Vines}

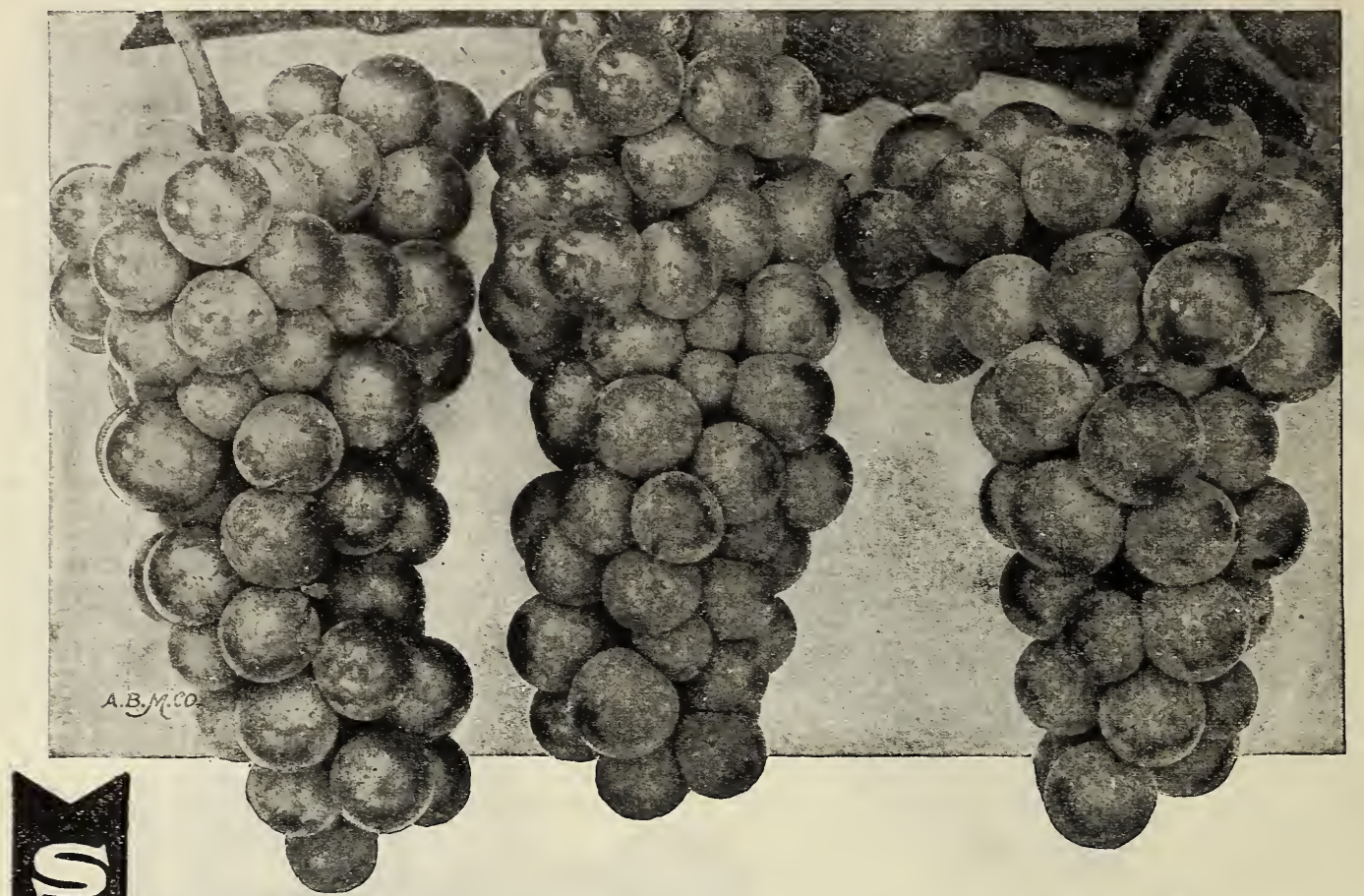

MOORE'S EARLY (Black). The best eariy black commercial grape, ripening as it does two or three weeks ahead of Concord. Vines vigorous, hardy and moderately productive.

NIAGARA (White). The leading commercial white grape, not as high in quality as Diamond, but more productive. In great demand. Holds the place among white grapes that Concord holds among blacks. Bunches and berries large and handsome, compact, and of good quality.

WORDEN (Black). This is a seedling of the Concord and while its berries and bunches are larger and the fruit is of better quality, it is not as good a keeper and does not ship as well to distant markets. It is a superior variety for home use and for nearby markets, and, on account of its high quality and large size, usually brings a higher price than Concord. For home use we know of no grape of greater value. Fruit ripens one or two weeks earlier than Concord.

AGAWAM (Red). An excellent keeper that may be kept in common storage until January. Large in both bunches and berries, dull purplish red, rich, sweet and of a decidedly foxy flavor.

DELAWARE (Red). A rich and delicately flavored little red grape that is generally recognized as the standard of quality to judge other grapes by. An exceptionally desirable variety for home gardens on account of its compact habit of growth.

BRIGHTON (Red). A very handsome dark red grape of high quality that should be in every home garden.

CAMPBELL'S EARLY (Black). The characteristics which give this grape its merit are high quality, freedom from foxiness, small seeds, earliness of maturity, large size and attractive appearance both of bunch and berry, hardiness and good keeping qualities.

\section{Extra Large Three-Year-Old Concord}

For those wanting quick results we can furnish the popular Concord variety in extra large well branched three-year vines. Priced as follows: Each, 40c; 6, \$2.00; 12, \$3.75; 25, $\$ 7.00 ; 50, \$ 12.50 ; 75, \$ 16.85 ; 100, \$ 21.50$.

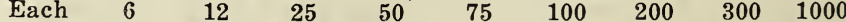

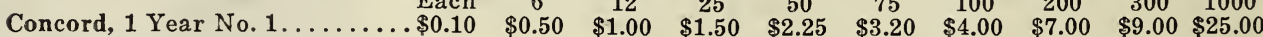

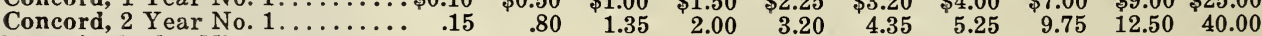

Moore's Early, Niagara,

Worden, Campbell's Early,

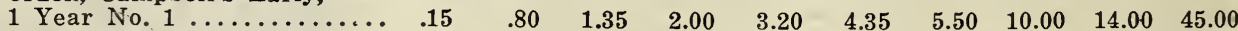

2 Year No. 1 .

35

Delaware, Agawam, Brighton,

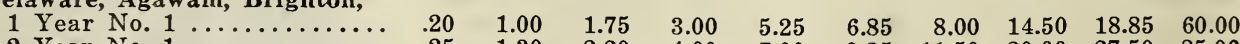

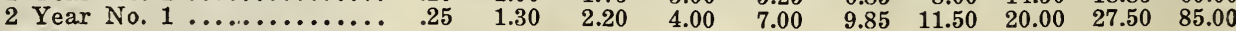

\section{$\rightarrow$ COLLCCTIONS ForYour GARDEN}




\section{Emlong's Choice Asparagus \\ The Famous Washington}

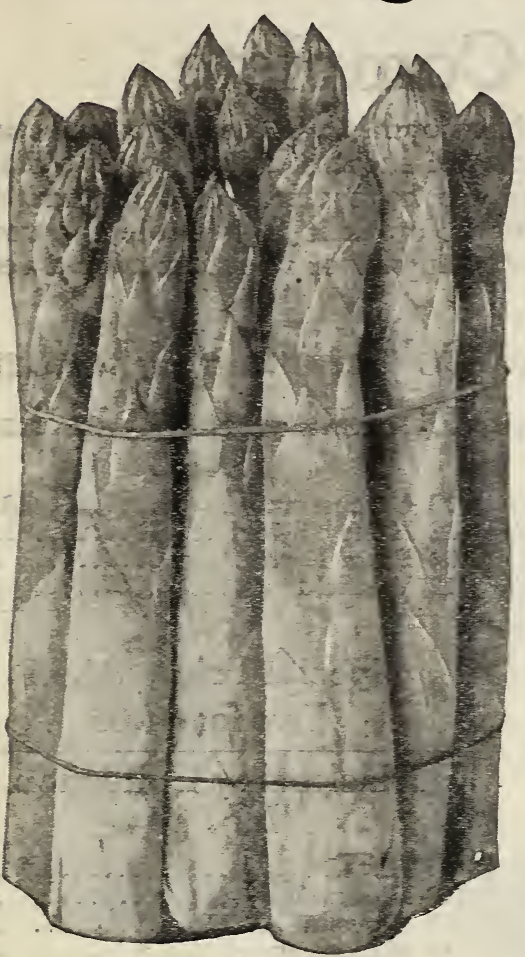

Washington Asparagus.

\section{Plant This Pedigreed Strain}

There is no variety of Asparagus as good as Washington, and whether you are growing for home use cnly or for market, you cannot-afford to grow any other. This wonderful new Asparagus was developed and introduced by the United States Department of Agriculture, and although it is just a recent introduction, it has become famous the country over.

\section{Rust Resistant-Profitable}

Growers everywhere are discarding all other varieties in favor of the famous Washington, because it is earlier, the stalks are larger, more tender, more productive than any other variety, and last but not least, Washington is immune to rust, which means that one planting will produce profitable crops for many years.

\section{Large-Early-Tender-Juicy}

Asparagus buyers everywhere now demand Washington and are willing to pay fancy prices to get it. The demand for Washington is tremendous because when it is once eaten, no other variety will give satisfaction. The stalks are a purplish green color, large, tender, and juicy. A very rapid grower, which means many cuttings.

\section{How to Grow Asparagus}

Asparagus is easy to grow and should be in every garden because it thrives everywhere. It supplies your table with the earliest of all Spring vegetables and one planting will last for 20 years or longer. April or May is the proper time to plant. Dig or plow a trench 10 inches deep, place the plants in this trench, spread the roots, then cover with two inches of soil, when the new growth comes through fill in two more inches and continue until trench is full. For garden culture Asparagus may be planted 18 inches apart each way but for field culture plant two feet apart in the row with the rows four feet apart. Do not cut stalks the first year. Plant our Extra Select Roots and you will have asparagus the second year.

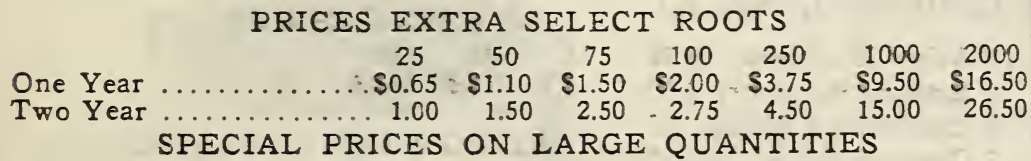

\section{Delicious Peach-Flavored Rhubarb}

Rhubarb is another big money maker because it provides material for early Spring pies and fresh table sauce. It is also extra fine for canning. Emlong's Extra Select Roots planted this Spring will give-you a big supply of this early "fruit" next Spring.

This fine new variety differs greatly from the old "pie plant", and the stalks are extra large, very tender, with a mild flavor. Yields abundantly and much earlier than the old common sorts.

Plant and grow rhubarb just the same as asparagus.

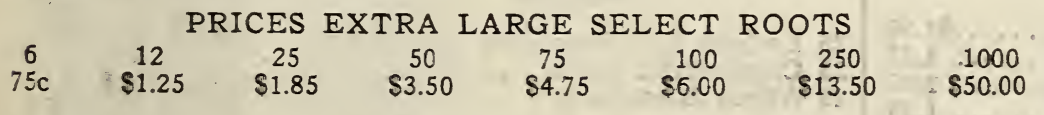

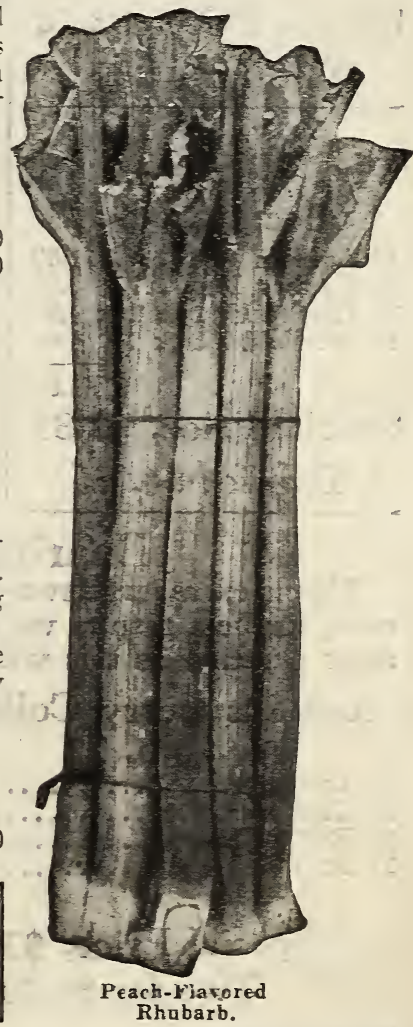

You can't get "something for nothing" so don't be fooled by low prices. The few cents extra you pay for QUALITY will be returned to you many times. 


\section{Emlong's Fruit Collections Make Your Home Complete}

Nothing else you could plant will give you as much enjoyment, pleasure, satisfaction and profit as your own Fruit Garden. The whole secret of success with fruit is to plant healthy, fruitful stock and select suitable varieties, and we have taken care of that because the following collections are composed of the finest stock it is possible to grow, and are so arranged that they will give you a continuous supply of fine fruit over a very

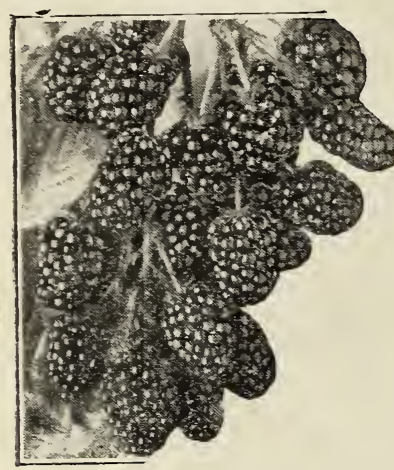

\section{Grape Collection} No. 16

12 Concord ........\$1.35

4 Niagara ........... .60

4 Campbell's Early.. .60

4 Agawam ....... .80

$\$ 3.35$

Special Price, $\$ 2.50$

Two for $\$ 4.50$

\section{Raspberry}

Collection No. 18

12 Latham. Red ....\$1.00

12 Victory Red ..... .85

12 Cumberland Black .85

12 Winfield Black ... .90

$\$ 3.60$

Special Price, $\$ 2.85$

Two for $\$ 4.75$ long season.

\section{You Can Order These Collections by Number}

Red Raspberry Collection BlackRaspberryCollection No. 10

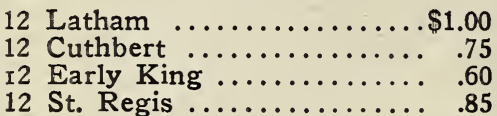

12 Cumberland ............\$0.85

12 Honey Sweet ............. 1.00

12 Plum Farmer ........... $\quad .85$

12 Winfield ................. .90

$\$ 3.20$

Special Price, $\$ 2.65$ Two for $\$ 4.50$

Special Price, $\$ 2.95$

Two for $\$ 4.85$

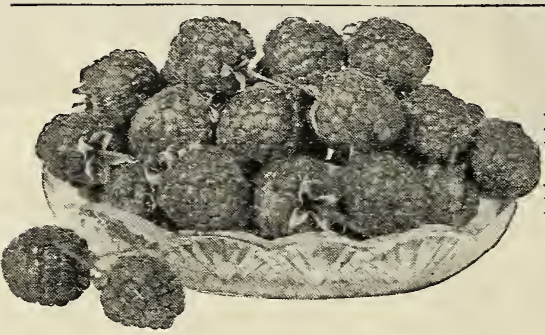

Blackberry Collection No. 14

12 Alfred ..................\$1.00

12 Eldorado $\ldots \ldots \ldots \ldots \ldots \ldots \ldots . .75$

12 Blowers $\ldots \ldots \ldots \ldots \ldots \ldots \ldots . .85$

12 Mersereau ............. $\quad .85$

Special Price, $\$ 2.65$

Two for $\$ 4.75$

Assorted Fruit Collection, No. 20

I2 Alfred Blackberry. $\$ 1.00$

12 Latham Raspberry 1.00

12 Cumberland Black. .85

6 Concord Grape ... .90

$\$ 3.75$

Special Price, $\$ 2.95$

Two for $\$ 5.00$

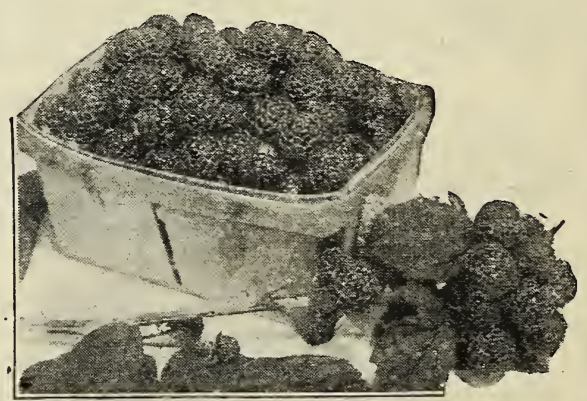

\section{Bearing Age Berry Bushes}

This is extra large two-year-old stock that will bear this year. However, for best results we advise cutting off the stalk near the ground after planting as this will assure a full crop of fruit next year.

Red Raspberry Collection No. 22

12 Latham .................\$1.50

12 Cuthbert ............... 1.25

12 Early King ................ 1.25

12 St. Regis ............... 1.35

Special Price, $\$ 3.95$

$\$ 5.35$

Two for $\$ 6.50$
Assorted Fruit Collection No. 24

25 Latham Red Raspberry .....\$2.25

25 Cumberland Black ........... 2.35

25 Alfred Blackberry ......... 3.25

$\$ 7.85$

Special Price, $\$ 6.45$

Two for $\$ 10.95$

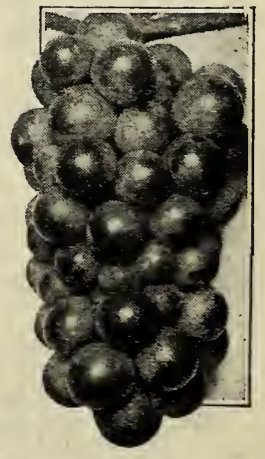




\section{It Costs YouLess Than Two Cents a Quart to Grow Your Own Fruit}

Do you know that you can grow a generous supply of fine fruit for home use practically without cost? Just devote some of that vacant space in your garden, back yard, along a fence or field to a few berry bushes and trees and you will have fruit to eat, fruit to can, fruit to sell and fruit to give away. Yes, I know you can buy, now and then, but for the price you pay for just a few quarts you can buy plants and trees that will give you a year-around supply.

You Can Order These Collections by Number

\begin{tabular}{c|c}
\hline $\begin{array}{c}\text { Apple Collection } \\
\text { No. 26 }\end{array}$ & \multicolumn{2}{|c}{ Peach Collection } \\
No. 28 \\
2 Early Harvest Summer & 2 Elberta \\
2 Grimes Golden Fall & 2 J. H. Hale \\
2 Jonathan Winter & 2 Rochester \\
2 Delicious Winter & Belle of Georgia \\
2 McIntosh Winter & 2 Crawford Late \\
10 First Class Trees & 10 First Class Trees \\
$\$ 3.35$ & $\$ 2.85$
\end{tabular}

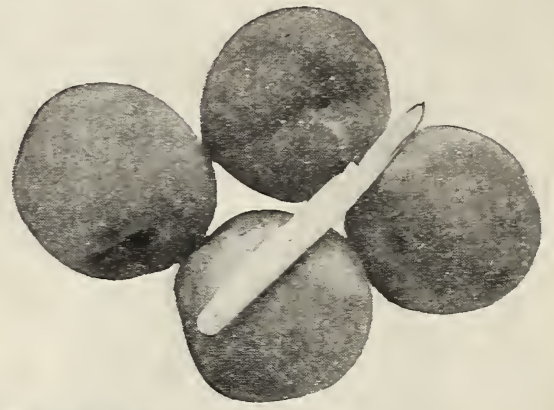

Cherry Collection No. 30

$\begin{array}{lll}1 & \text { Montmorency } & 1 \text { Schmidt } \\ 1 & \text { Early Richmond } & 1 \\ 1\end{array}$

5 First Class Trees, $\$ 2.35$

Plum Collection No. 32

1 Abundance

1 Monarch

1 Burbank

1 German Prune

1 Yellow Egg

5 First Class Trees, \$2.25

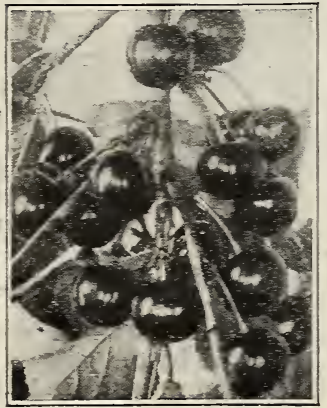

Peach and Apple Collection No. 36

2 Grimes Golden Apple

2 Delicious Apple

2 Elberta Peach

2 Rochester Peach

2 Early Harvest Apple

10 First Class Trees $\$ 3.00$

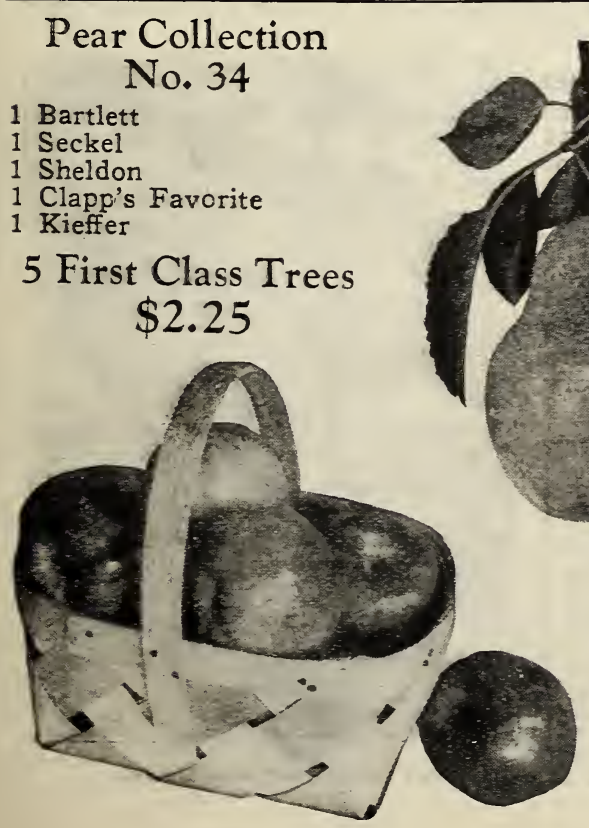

Complete Family Orchard Collection No. 40

2 Early Harvest Apple

2 Delicious Apple

2 Elberta Peach

2 Rochester Peach

2 Bartlett Pear

2 Seckel Pear

2 Black Tartarian Cherry

2 Montmorency Cherry

2 Yellow Egg Plum

2 Abundance Plum

2 Superb Apricot

2 Orange Quince

24 First Class Trees, $\$ 7.85$

Peach, Apple, Cherry Collection No. 38

1 Elberta Peach

1 J. H. Hale Peach

1 Delicious Apple
1 Grimes Golden Apple

I Montmorency Cherry

1 Black Tartarian Cherry

6 First Class Trees, $\$ 2.45$ 


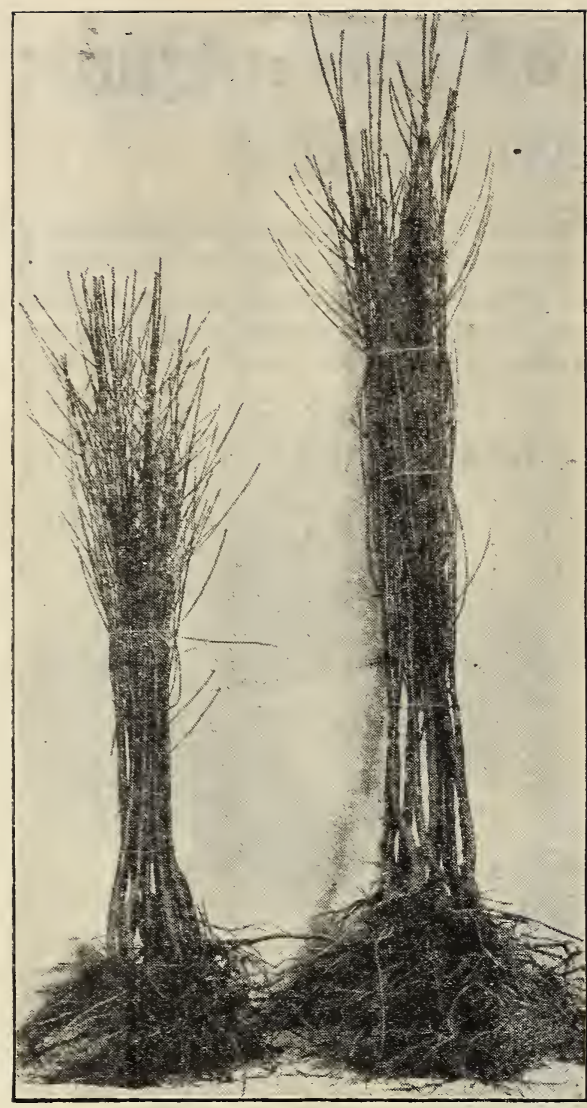

Medium Grade. $\quad$ No. 1 Grade. All Straight and Well Rooted.

\section{Emlong's Whole Root Fruit Trees}

\section{The Best That Money Can Buy}

Planting nursery stock of any kind is a mighty important proposition and you cannot be too careful in making your selection because your success, satisfaction and perhaps your whole future is at stake.

When you plant an Emlong fruit tree you are planting the best that money can buy. Emlong's plants and trees have a national reputation for long life, health, vigor and productiveness and we cannot afford to send a single Emlong customer anything but the very finest stock it is possible to produce.

\section{Save a Year or More}

Time is money, don't waste it by planting small, spindling, poorly rooted trees commonly known as "whips". Even if they do grow (which is doubtful) it will take them a long time to come into bearing.

The picture at the left shows you the "class" of our sturdy, well rooted trees and when you plant this kind of stock you are making the right start and will have bearing trees in the shortest possible time.

\section{Hardy, Northern, Upland Grown}

Emlong's trees ARE NOT piece-root trees. They are grown on rich, well drained, upland soil, propagated on whole root, imported seedlings. This assures the heavy, fibrous root systems for which our trees are famous. This method of propagation is recognized by leading authorities everywhere as the only way to produce high grade trees, and these same authorities will tell you that our hardy northern grown trees are the safe and sure kind to plant.

\section{All the Roots-All the Life}

That is what you want and will have when you plant an EMLONG tree. Anyone knows that a plant or tree with all of its roots is better than a plant or tree with half of its roots. Our long experience in growing, handling, digging and packing nursery stock has taught us how to handle plants and trees quickly and in such a manner that will at all times protect roots, trunk and limbs from injury. Our stock starts growing quickly after planting, because you get all of the roots, life and vigor.

\section{Price versus Quality}

At the beginning of this page we told you that Emlong's trees are "the best that money can buy", and that's true in spite of the fact that you will find our price within reason. Folks who are asking two or three times our prices will resent this statement but they KNOW it is so. You cannot judge the value of nursery stock by the prices you pay. The ability and experience of the men you are dealing with is what counts. We know that it is impossible to produce better plants, trees and shrubs than we are offering because we have the finest soil in the world and no expense is spared in growing, handling and packing. If we thought that we could improve the quality by spending more money we would not hesitate to do so because quality in nursery stock is of the utmost importance.

HOW TO PLANT FRUIT TREES

Fruit trees will thrive on any well drained soil. Prepare it same as for your garden or ordinary farm crops. Plant in April or May. Dig a hole a foot square and 10 or 12 inehes deep, keeping the top soil separate so that it can be placed on the roots. Set the tree 2 inches deeper than it was in the nursery, tramp and pack the soil firmly to eliminate all air pockets. If dry use plenty of water when planting and during the Summer water often enough to keep the soil moist but not soggy. Before planting prune often enough to keep the soil moist but not soggy. Before planting prune
off any roots that may have been broken or bruised, also the ends of all long roots. After planting prune as follows: Pear and Apple trees, select 3 to 5 branches and remove all others. Cut branches back to 8 or 10 inches. Peach trees should be cut back to 24 to 30 inches, and all limbs cut back to stubs with 2 or 3 bud.s. Apricot and Plum should be pruned same as Peach, but not so severe. Cherry should be pruned but moderately if at all. Prune trees in Spring only, but remove any dead or broken limbs at all times.

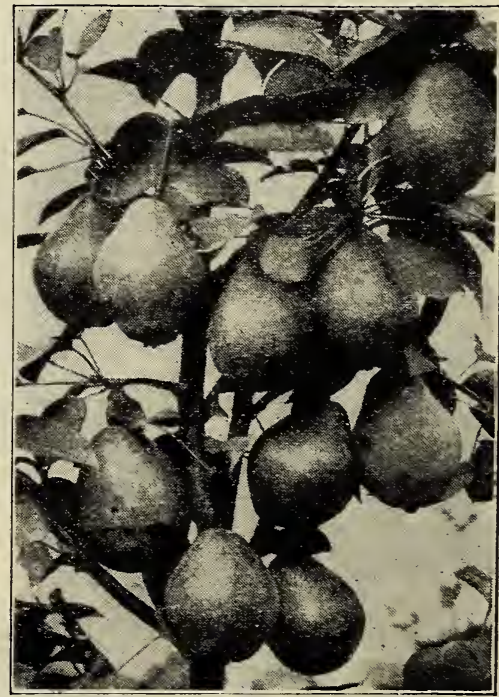

Fast Growing-Young Bearing. 


\section{Three Famous New Varieties}

Plant them this spring with every assurance that you will have something better than you have ever had before.

These three new fruits have been thoroughly and impartially tested by leading authorities everywhereExperimental Stations, Horticulturists and leading Fruit Growers acclaim them as vastly superior to all other varieties in their class.

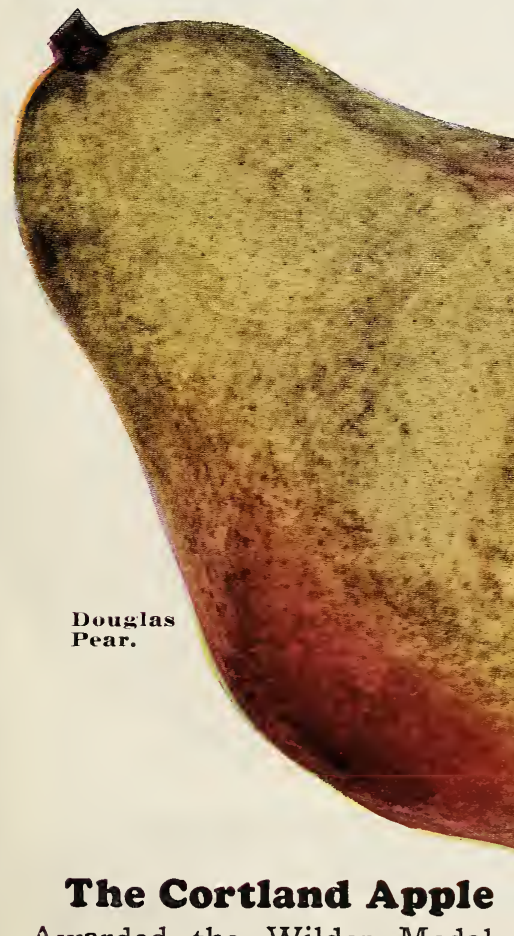

Awarded the Wilder Medal for new fruits by the American Pomological Society, proving it superior to all other apples. For complete description see page 40 .

\section{The Douglas Pear}

This is the new quick growing, young bearing, blight resisting Pear that makes it possible for everyone to enjoy this delicious fruit. Hardier than any other. Complete description page 42 .

\section{The Caco Red Grape}

Juicy, sweet and delicious, equalling the finest varieties grown under glass. Caco is the earliest ripening and heaviest yielding of all red grapes, bunch and berry large. Further description page 32 .

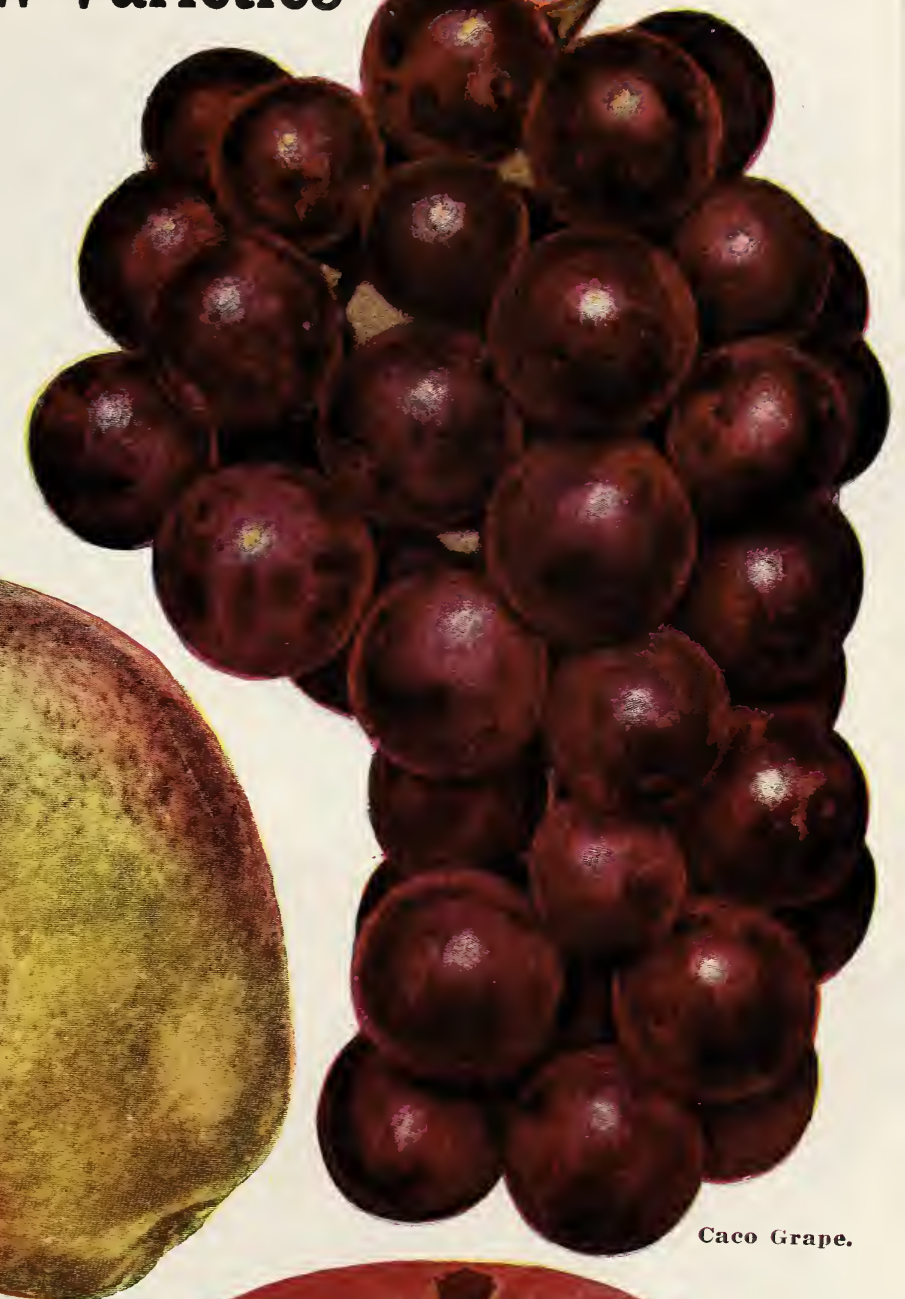




\section{SOUTH HA VEN - NEW PEACH}

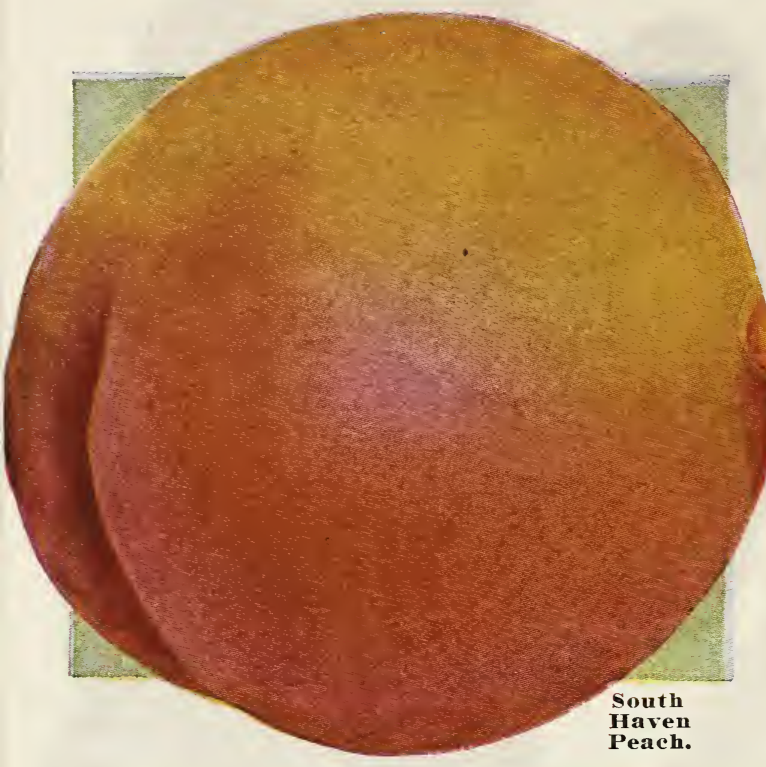

Plant this Extra Big, Extra Fancy, Extra Early Yellow Peach for home use and for market. It combines every good feature of the famous Elberta -immense productiveness, large size, fine quality, excellent flavor, beautiful appearance-BUT IT RIPENS 14 to 20 DAYS EARIIER. In th:s Great Fruit Belt of Southwestern Michigan whole orchards are being planted to South Haven. These far-sighted growers know that it will bring them BIG PROFITS. The tree is hardy, healthy, vigorous, and its quick growing, young bearing habit is remarkable. You cannot go wrong in planting South Haven no matter what your requirements may be. PRICE-4 to $5 \mathrm{ft}$. trees, each, $40 \mathrm{c} ; 10, \mathrm{~S} 3.75$; $50, \$ 17.60 ; 5$ to $6 \mathrm{ft}$.trees, each $60 \mathrm{c} ; 10, \$ 5.50 ; 50$, $\$ 25.00$.

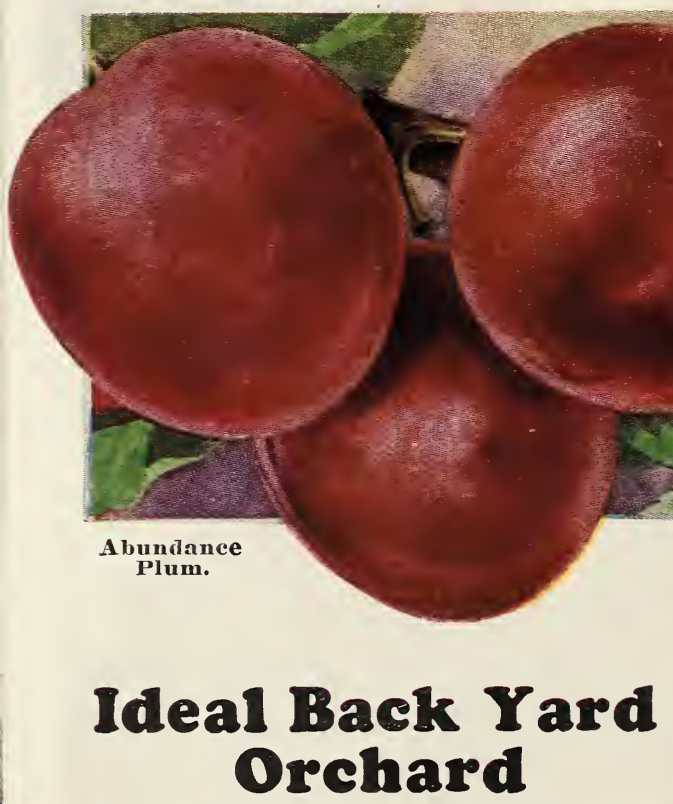
$\$ 3.85$ for Twelve 3 to $5 \mathrm{ft}$. Trees
$\$ 5.00$ for Twelve 5 to $7 \mathrm{ft}$. Trees

1 Delicious Apple

1 Grimes Golden Apple

1 Elberta Peach

1 Rochester Peach

1 Bartlett Pear

1 Kieffer Pear

When ordering just say-One 3 to $5 \mathrm{ft}$. (or 5 to $7 \mathrm{ft}$.) Ideal Back Yard Orchard.
1 Black Tartarian Cherry

1 Montmorency Cherry

1 Yellow Egg Plum

1 Abundance Plum

1 Superb Apricot

1 Orange Quince 


\section{Emlong's Choice Peach Trees}

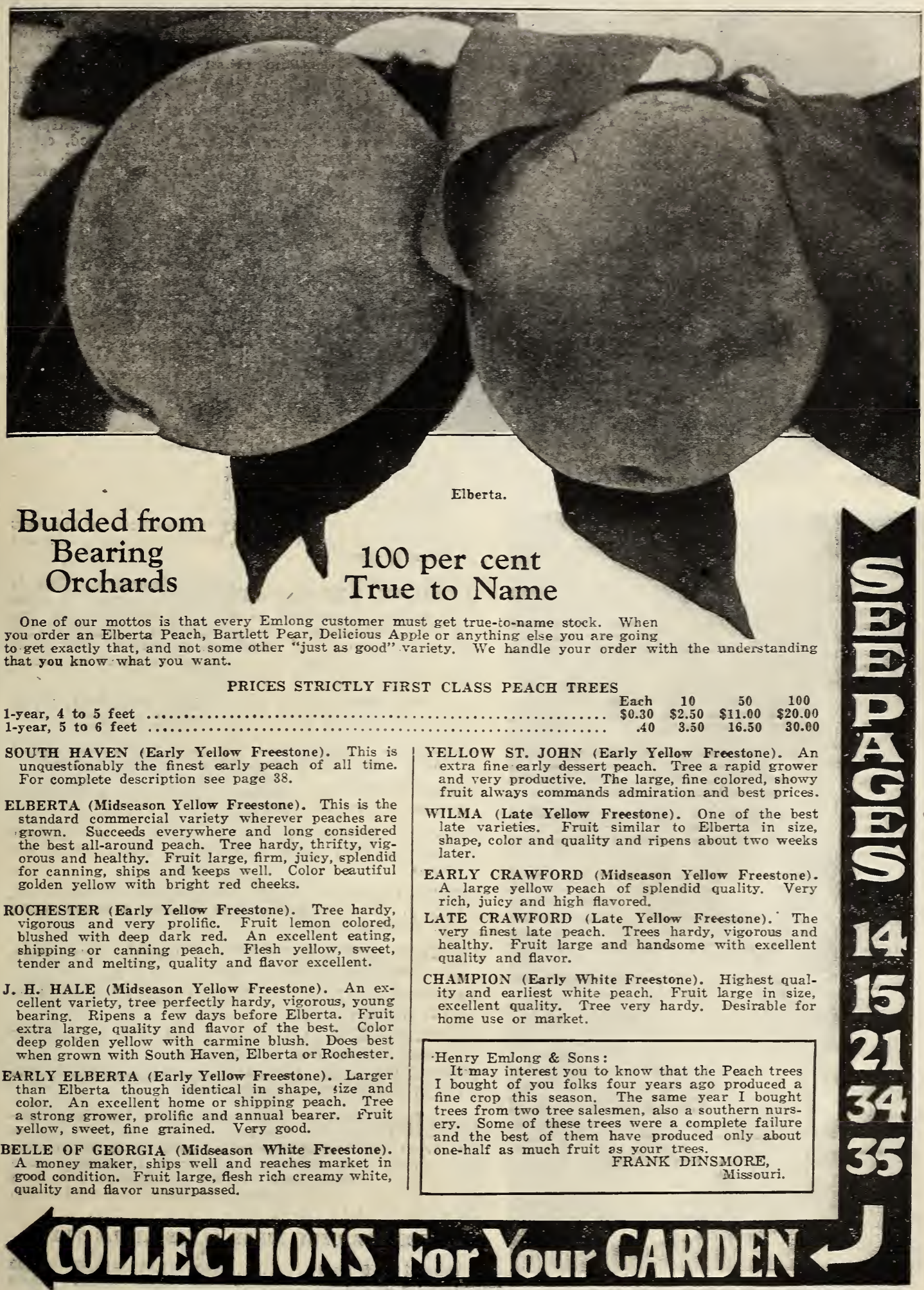




\section{Emlong's Choice Apple Trees}
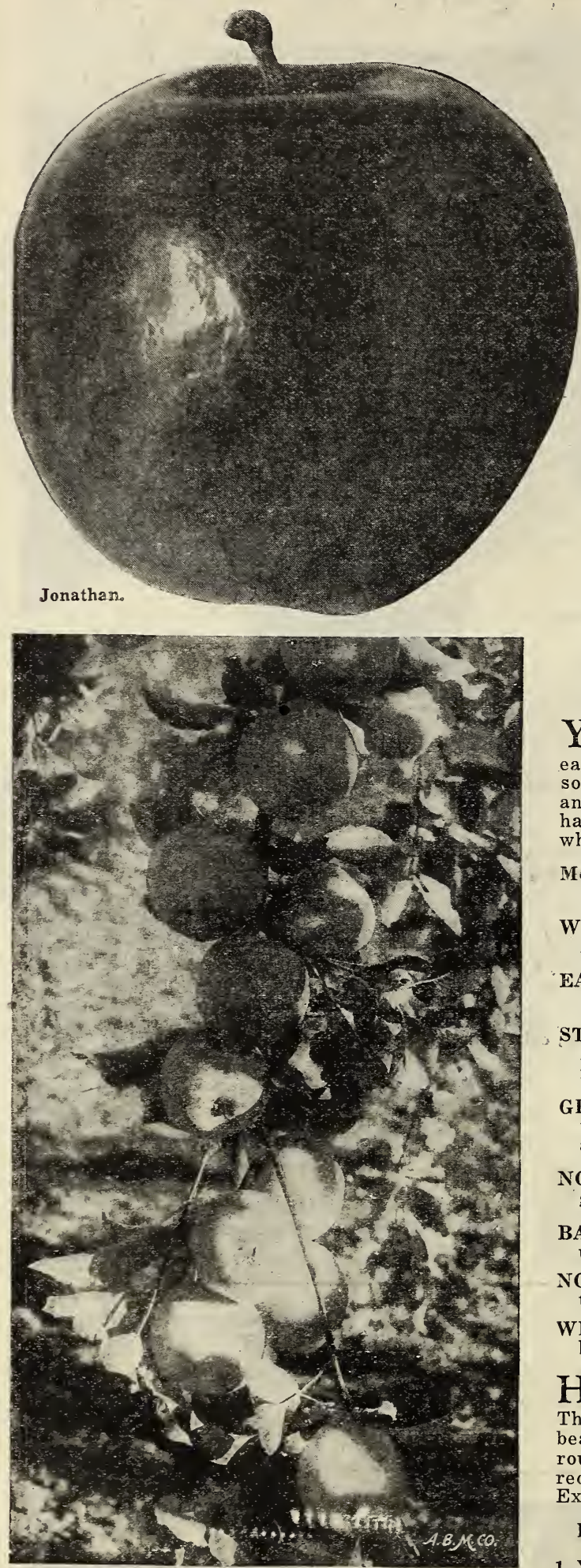

Yellow Transparent.

The New Cortland (Late Fall). A riety of the McIntosh type originated by Professor U. P. Hedrick of the New York State Department of Agriculture. Cortland promises to establish itself as one of the greatest of all eating and Market Apples. The fruit is larger than that of McIntosh, round to conical in shape. Color a beautiful dark red, splashed and striped with carmine, overlaid with deep purplish bloom. The flesh is white, firm, fine grained, crisp tender, and juicy. Aromatic; fine for dessert. The trees are large, very hardy, productive and healthy. Bears very young and full crop every year. Hangs well to tree and is an excellent keeper as it is not bruised in handling. Prices, 2 yr., 5 to $6 \mathrm{ft}$. trees, each, 70c; $10, \$ 6.00 ; 50, \$ 27.50$.

Delicious (Winter). Known in some localities Delicious as Stark's Delicious. Our stock is guaranteed the genuine True Delicious. This is undoubtedly the most popular Apple grown today, commanding a premium on all markets. Tree one of the hardiest, a vigorous grower, with beautiful foliage, and a heavy, annual bearing type. Fruit large, somewhat conical in shape. Color a beautiful crimson, mottled with dark red. Flesh fine grained, crisp, tender, juicy. Quality superb, an excellent shipper and keeper.

Tonathan (Winter). .A very beautiful, bright Jonathan red apple, highly flavored and of excellent quality for dessert or culinary uses. Highly prized and in much demand as a fancy apple during the holiday season. The fruit is tender, juicy, spicy and rich. A splendid family sort and one of the best for market. Tree vigorous, long-lived, productive and an early bearer.

Yellow Transparent (Summer). This is the very finest extra son until September. Tree a vigorous, upright grower and a very early and abundant producer. Extremely hardy. Fruit of good size, waxy yellowish color. Flesh white, mild, juicy and pleasant.

MeINTOSH RED. (Late Fall). One of the best. Fruit spicy, bright red and of the highest quality.

WEALTHY. (Early Fall). A good midsummer apple. Fruit striped red, tender, juicy. A heavy bearer.

EARLY HARVEST. (Summer). Fruit waxy yellow, flesh tender, juicy, good flavor.

STAYMAN WINESAP. (Fall). Succeds everywhere. Fruit dark red, tinged with yellow. Fine quality and flavor.

GRIMES GOLDEN. (Fall). Very popular. Tree strong, thrifty. Skin and flesh yellow, fine for eating, cooking and market.

NORTHWESTERN GREENING. (Winter). Fruit large, greenish yellow, fine grained.

BALDWIN. (Winter). A fine red apple that will keep until March or later.

NORTHERN SPY. (Winter). Large, rich, red. Keeps through Winter and late Spring.

WINTER BANANA. (Winter). Color lemon-yellow with bright red cheek. Banana flavor. Hyslop (Crab). This variety has long been conThe trees are healthy, vigorous, with beautiful foliage, bear young and annually. The fruit is large, nearly round with smooth skin. Color a beautiful rich dark red on yellow. Flesh yellow, crisp, juicy, sub-acid flavor. Excellent for all culinary uses.

PRICES STRICTLY FIRST CLASS APPLE TREES

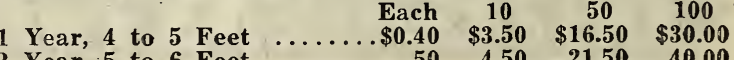

? Year, 5 to 6 Feet $\ldots \ldots \ldots . .50 \quad 4.50 \quad 21.50 \quad \mathbf{4 0 . 0 0}$

Page Forty 


\section{Emlong'sChoiceCherryTrees}

EARLY RICHMOND. The earliest sour Cherry grown; one of the most popular and valuable of the acid varieties. Fruit medium size, dark red, melting and juicy; unsurpassed for cooking and canning. Tree slender growing; exceedingly productive, very hardy, as it will stand the most severe Winter.

LARGE MONTMORENCY. A beautiful, extra large, red, sour Cherry. Fruit larger and firmer than Richmond; ripens about 10 days later. A strong grower, absolutely hardy, bears young and is a sure cropper. There is a big demand everywhere for this fine Cherry.

\section{PRICES}

OF FIRST CLASS SOUR CHERRY TREES

$\begin{array}{llll}\text { Each } & 10 & 50 & 100\end{array}$ 1 -year, 4 to 5 feet .... \$0.45 $\$ 4.00 \quad \$ 18.50 \quad \$ 35.00$ 2-year, 4 to 6 feet ..... .60 $5.50 \quad 25.00 \quad 45.00$ WINDSOR. Exceedingly valuable for late market and home use. A fine, large, dark red Cherry that hangs on a long time and rots but little. The flesh is remarkably firm and good. Sweet.

BING. The grand new sweet Cherry; originated in Oregon. Flesh very solid, flavor of the very highest quality. A fine shipper; perfectly hardy and very prolific. Sweet.

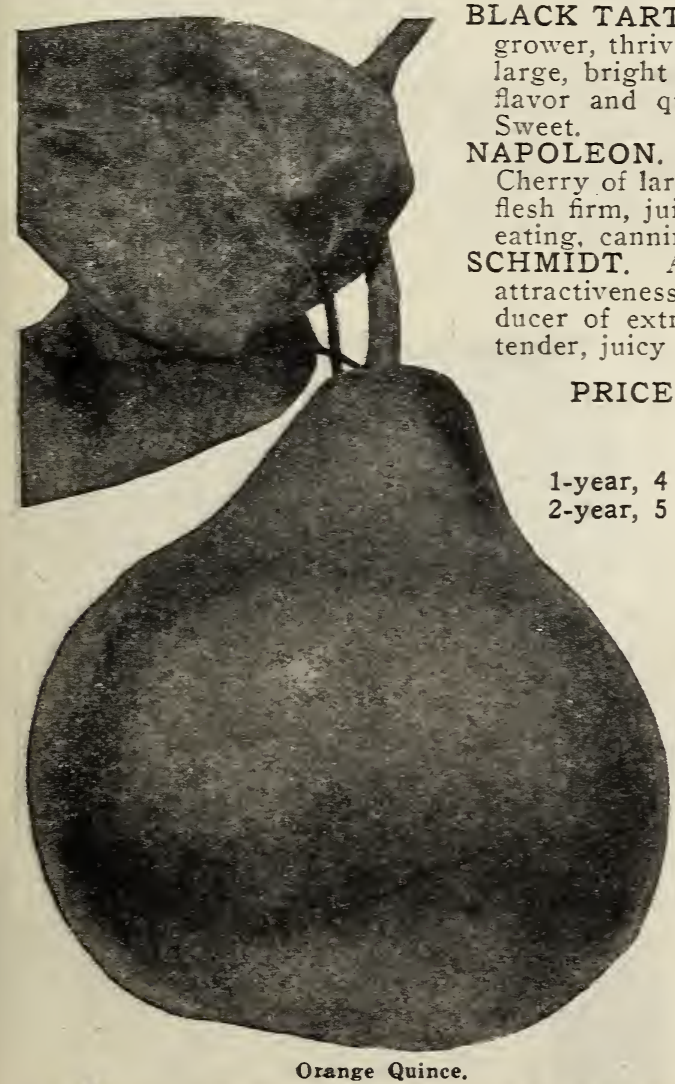

BIACK TARTARIAN. Tree perfectly hardy, a vigorous grower, thrives everywhere; very productive. Fruit very large, bright purplish black; juicy, sweet, rich, excellent flavor and quality; fine for eating, canning or market. Sweet.

APOLEN. Sometimes called Royal Anne. A beautiful Cherry of large size; pale yellow, with bright red cheek; firm, juicy and sweet; one of the best Cherries for

A splendid market Cherry, because of its all-around good qualities. A big producer of extra large Cherries; rich deep crimson color; tender, juicy and extra well flavored. Sweet.

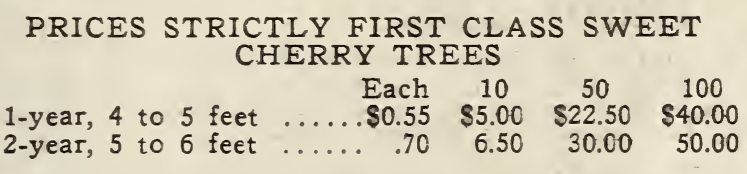

\section{Quinces}

ORANGE. The finest Quince grown. Trees bear young and are very produc. tive. Fruit large, orange-shaped and of excellent flavor. Orange is the best known and best liked of all varieties. 2 yr., 4 to $6 \mathrm{ft}$., $75 \mathrm{c}$ each; 10 for $\$ 7.00$.

\section{Apricots}

SUPERB. Medium size; light salmon with slight blush; flesh firm and solid, and excellent flavor. Grows large and spreading; very hardy and productive. 2 yr., 4 to $6 \mathrm{ft} ., 60 \mathrm{c}$; 10 for $\$ 5.00$.
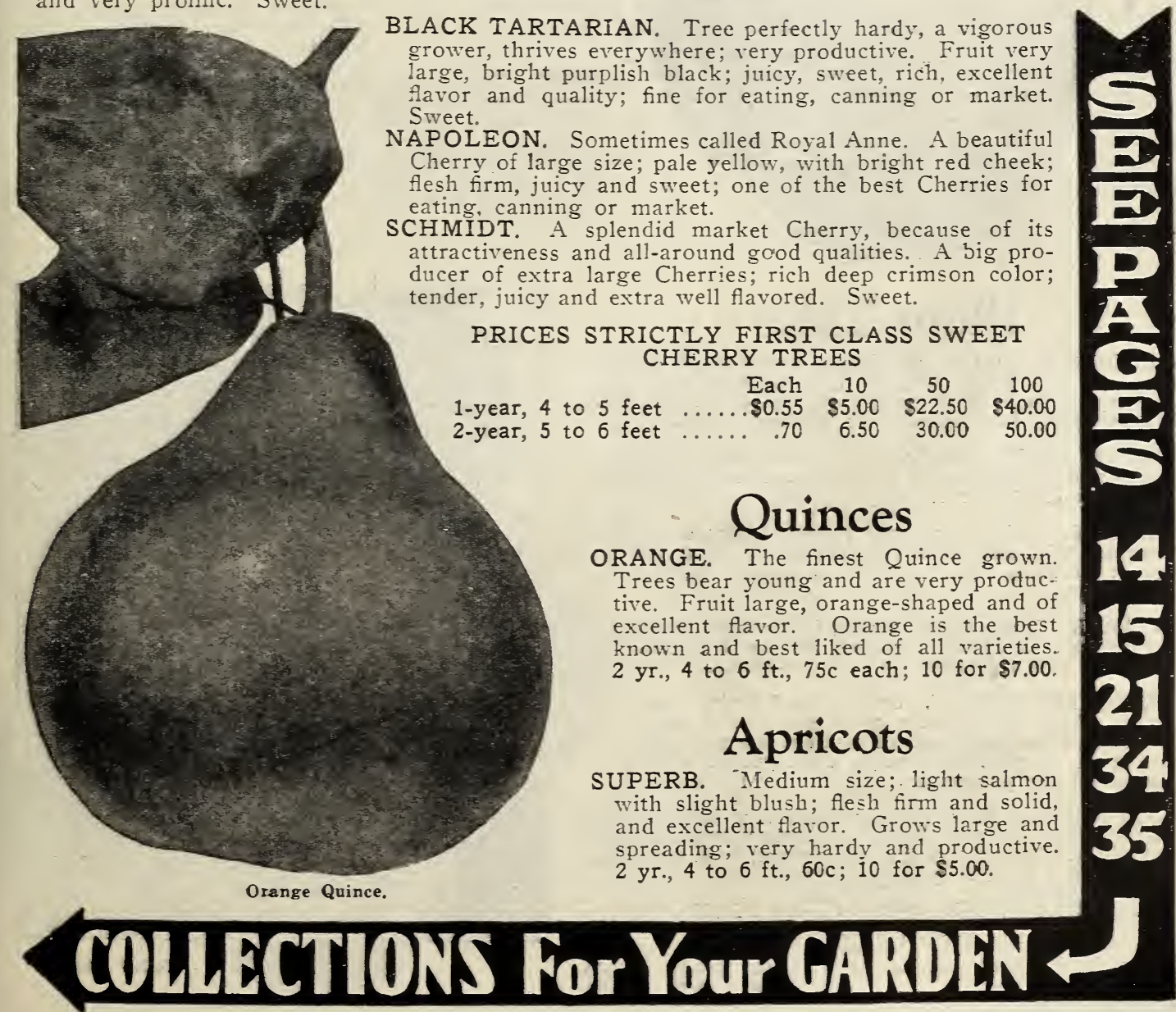


\section{Emlong's Choice Pear Trees}

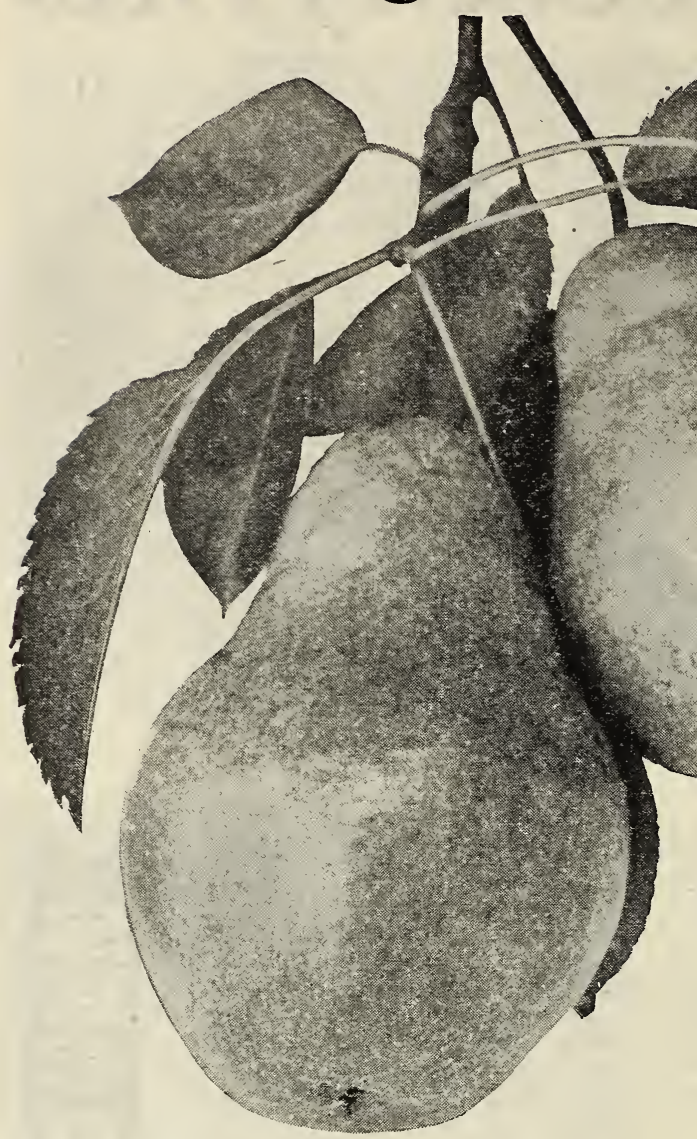

The New Douglas

Here at last is a blight proof and cold resistant Pear that you can plant with safety and certainty of big, quick returns both in fruit and profit. Douglas has proven itself a heavy regular cropper in all soils and all localities. It often bears the same season it is planted. The fruit is large, smooth, with a beautiful golden yellow color, flecked with russet. The flavor is simply delicious, very sweet, melting and juicy. Plant a couple of trees of Douglas for your own use and you will have America's Finest Pear. Price, 2 year, 5 to $6 \mathrm{ft}$. trees, $\$ 1.00$ each; 5 for $\$ 4.50 ; 10$ for $\$ 8.00$.

BARTLETT. Undoubtedly the finest Pear grown. A big producer; ripens early. Golden colored with red cheek; flavor and quality the best.

KIEFFER. This is the well known canning Pear; a big producer and sure cropper; hardy, proliflc; fruit large, yellowish, good quality.

SECKEL. This is the small, rich, sweet Pear, so widely grown for preserving and home use; succeeds everywhere and a big sure cropper.

CLAPP'S FAVORITE. Tree hardy, vigorous and upright grower. Fruit large and fine looking; flesh juicy, sweet and rich.

\section{Plum Trees}

ABUNDANCE. One of the best; tree a rapid grower, healthy and bears young; very productive. Fruit nedium size, a rich bright cherry-red; flesh light yellow, juicy and tender, tree vigorous and hardy.

GERMAN PRUNE. Medium oval; purplish blue, rich, juicy and of high flavor; tree vigorous and productive; good for drying or canning.

BURBANK. Medium to large; orange-yellow, dotted and marbled with red; flesh meaty, yellow, sweet and good; valuable for canning and a good market Plum.

MONARCH. Large, nearly round, dark purple, juicy and sweet. A splendid shipper and good market variety; tree vigorous and very productive.

SHROPSHIRE DAMSON. One of the favorite Damsons. Fruit oval; tree a good grower and enormously productive; fruit of medium size produced in thick clusters or groups, dark purple color, esteemed for preserving.

YELLOW EGG. An extremely hardy new variety combining best features of both American and Japanese varieties. Fruit large, flavor delicious, dark red color. Produces a good crop at two years.

PRICES STRICTLY FIRST CLASS PLUM AND PEAR TREES

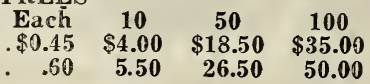

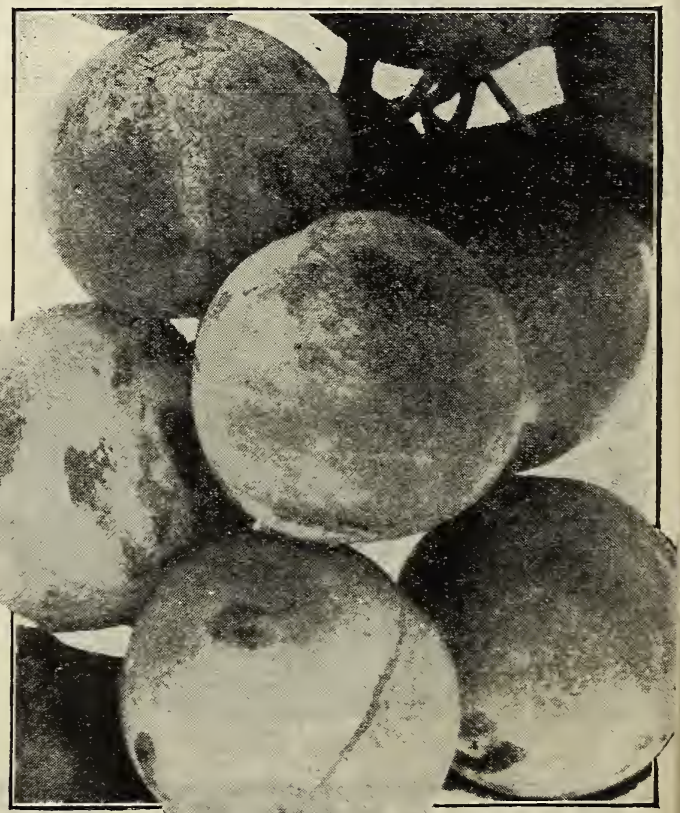

Yellow Egg. 


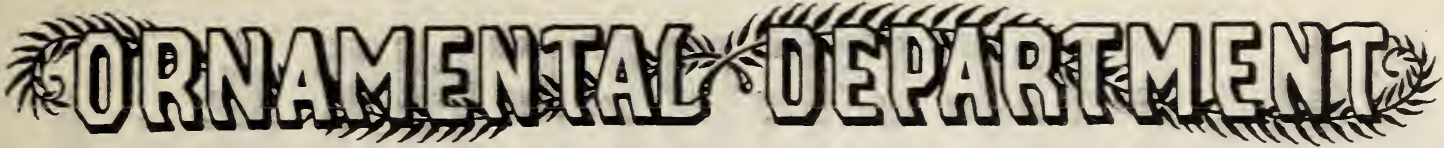

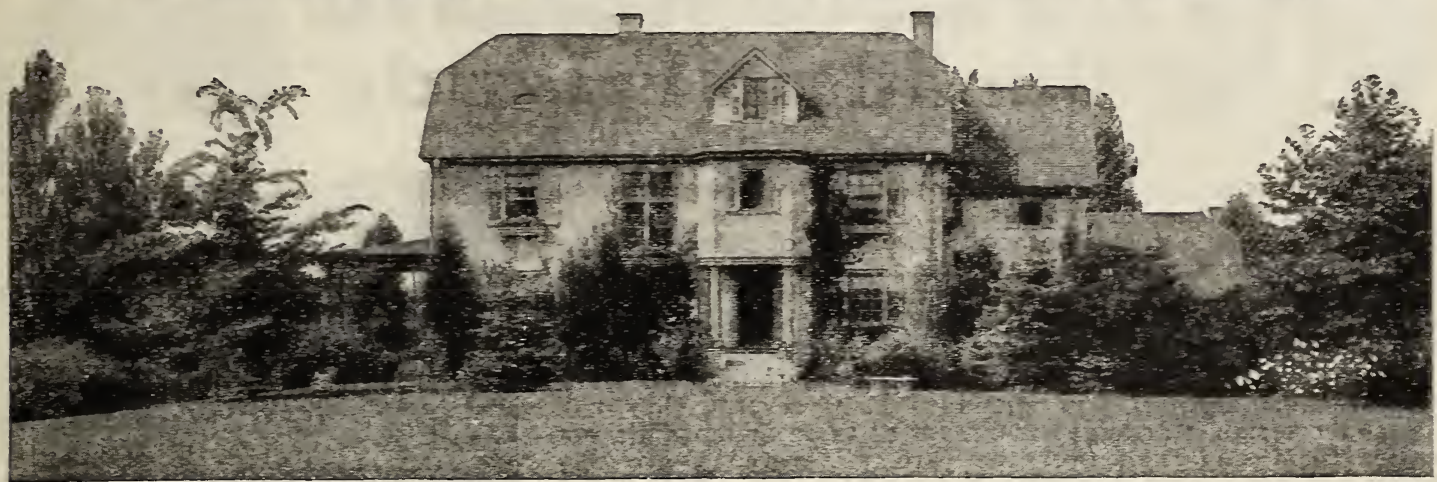

\section{Announcement to Emlong Customers}

For many years we have offered a limited number of flowering shrubs, hedge plants, rose bushes and bulbs to our customers, along with our fruit plants and fruit trees. The quality of our stock and low prices have made many friends, and we now feel that our customers would appreciate a wider variety of ornamentals to select from. We have extended our offerings of shrubs, roses, and gladiolus bulbs, as well as adding shade trees and evergreens.

\section{Landscape Service}

Quite often the home owner is not familiar enough with the various trees, shrubs, etc., to place them where they will appear to the best advantage. For this reason we have established a Landscape Department intended to aid our customers. If you are making a simple planting, no doubt you will need only a letter of suggestions.

However, if you plan to enlarge your plantings considerably or make an entire new planting you will need a definite plan.
We furnish plans drawn in ink to large buyers. If this service is desired, write us for a planting sketch blank. You will fill out the blank as instructed and send it to us with a deposit of $\$ 5.00$. We then make the complete plan and submit it to you with a planting list and price of the entire order. On rcceipt of your purchase order for the shrubs, we deposit the $\$ 5.00$ to your account and the plan will cost you nothing.

\section{Is Your Home Investment Balanced?}

Everyone is interested in having the finest possible furnishings for the interior of their home. You add something to it every year. Do you do the same with your home grounds? You and a few friends can enjoy the interior of the home, but did you ever consider how many more people can enjoy a beautifully landscaped exterior? You should aim to make your place stand out as a beauty spot in your community.

Have you balanced your investment? If your house is valued at $\$ 6,000$, your outside improve-

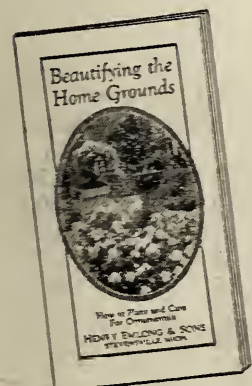
tenth of that amount, or $\$ 600$.
This amount does not all need to be spent in one year, but may be started this year and continued over a period of seasons. Real estate men agree that a complete landscape planting increases the value of property at least $25 \%$ to $50 \%$. Then consider the satisfaction and pleasure you can gain from a beautiful yard, and you will realize that you cannot afford to leave your grounds unplanted.

No matter whether you own a small city lot, a suburban home, or a country estate, you will find our list of ornamentals complete enough to care for your needs.

\section{Get This Valuable Booklet}

To our customers who are buying ornamental nursery stock this season, we offer for the first time a special booklet on the planting and care of this class of stock. "BEAUTIFYING THE HOME GROUNDS", contains all practical information needed for the proper care of shrubs, shade trees, evergreens and bulbs, after they are received from the nursery as well as suggestions for their arrangement on the home grounds. Every customer who sends an order for ornamental stock amounting to $\$ 5.00$ or more will receive a copy free on request. Those ordering less than $\$ 5.00$ worth of ornamentals may secure a copy by remitting $10 \mathrm{c}$ extra with their order. 


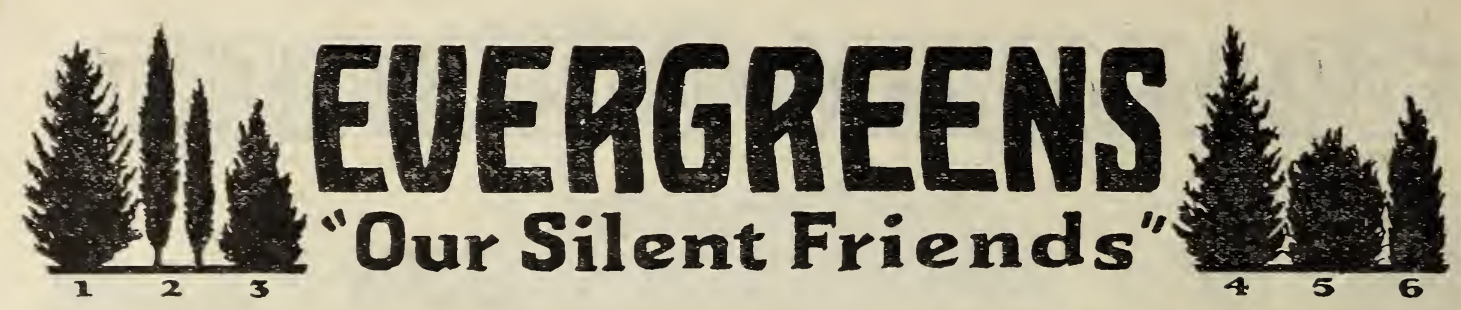

From a practical and pictorial point of view we have all been
slow in learning that evergreens, although expensive, are most
useful and desirable to plant near the dwellings of Man. In Win-
ter months contrasted with the white snow and grey twigs of
other trees, evergreens suggest warmth and cheer. In Summer
their heavier greens against the paler, changing colors of de-
ciduous trees and shrubs suggest shade and coolness. When
planting these trees, be careful to place them where they will show
to best advantage. If you intend to plant several, they will
appear more rich if arranged in groups of three or more, do not
scatter them singly all over the yard. Evergreens, properly
planted. lend a charm and richness to your grounds which cannot
be accomplished with deciduous trees and shrubs.

AMERICAN ARBOR-VITAE. The nother of all Arbor-Vitaes.

Usually grows bushy at bottom, tapering toward top. Foliage soft, flexible and deep green. Tery hardy. Prefers moist location, but does well anywhere. May be trimmed for hedges. (See No. 6 in border). Rapid grower.

PYRAMIDAL ARBOR-VITAE. Compact form. Foliage dark green with lighter tips. Crowded, fernlike branchlets. Best pyramidal evergreen. Reaches height of 12 to 15 feet.

GOLDEN ARBOR-VITAE. A plant of exceptional merit. Bright golden foliage. Rather a slender tree, reaching a height of 12 to 15 feet, with base diameter of 2 to $2 \mathrm{r} / 2$ feet. Makes a

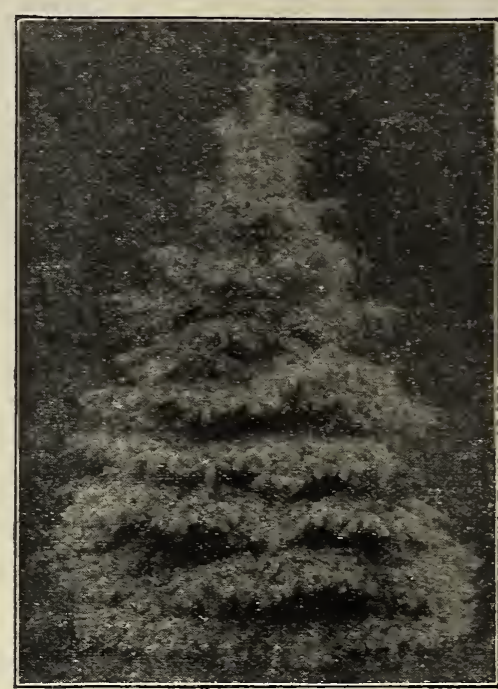

Colorado Blue Spruce. fine contrast with the green of other varieties. (No. 3 in border).

NORWAY SPRUCE. A very popular tree because of its rapid growth, heavy masses of foliage and thrifty habits. May be pruned to any height, and is widely used for windbreak purposes. Deep green color. (No. 1 in border).

COLORADO BLUE SPRUCE. The most showy of all Spruces. Beautiful silvery blue foliage. Fine for lawn specimen or grouping with other evergreens. Lends a rich appearance to the entire landscape.

COLORADO GREEN SPRUCE. Same habit of growth as the blue variety, but having dark green foliage. A very worth-while variety.

WHITE PINE. Grows to a greater height than any other evergreen. Adapts itself to.any soil, can endure more shade than other varieties, and grows rapidly. Leaflets soft, bluish green, whitish beneath. Branches horizontal, general shape forms into symmetrical pyramid. 100 to 120 feet at maturity. (No. 4 in border).

MUGHO PINE. The old definition, "Short and stout and round about," applies well to this variety. It is a dwarf type with many stems, compact form and dark green foliage. New growth is light green and appears as little candles all over the top of the tree. Grows well anywhere and is free from insect pests. Grows 4 to 5 feet tall. spreading out to a diameter of 6 to 8 feet. May be pruned. A very valuable and distinct evergreen. (No. 5 in border).

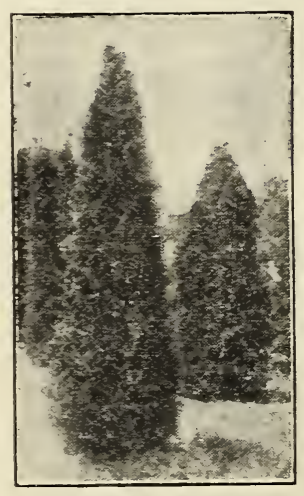

Pyramidal Artor-Vitae.

IRISH COLUMNAR JUNIPER. An old, familiar evergreen. Very formal in outline and valuable to use in emphasizing architectural features of certain types of houses. Foliage glaucous green. Grows 6 to 8 feet in height, and not over $1 \mathrm{I} / 2$ feet in diameter. Numerous branches grow upright from base of tree. Not hardy in extreme North. (No. 2 in border).

\section{PRICES OF EVERGREENS}

$11 / 2$ to 2 feet.

Roots Balled and Wrapped. Transplanted Seedlings.

American Arbor-Vitae ....... \$1.50

Pyramidal Arbor-Vitae ...... 2.50

Golden Arbor-Vitae ......... 2.50

Norway Spruce ............. 1.50

Colorado Blue Spruce ....... 4.50

Colorado Green Spruce ...... 3.00

White Pine .............. 1.50

Mugho Pine ............... 4.50

Columnar Juniper $\ldots \ldots \ldots \ldots \ldots 2.50$ 10

$\$ 13.50$

22.50

22.50

13.50

40.09

27.50

13.50

40.00

22.50

$\begin{array}{rr}3 & 25 \\ \$ 1.00 & \$ 7.50 \\ 1.50 & 10.00 \\ 1.50 & 10.00 \\ 1.00 & 6.00 \\ 2.25 & 15.00 \\ 1.50 & 10.00 \\ 1.00 & 7.50 \\ 2.25 & 15.00 \\ 1.50 & 10.00\end{array}$

Page Forty-four 


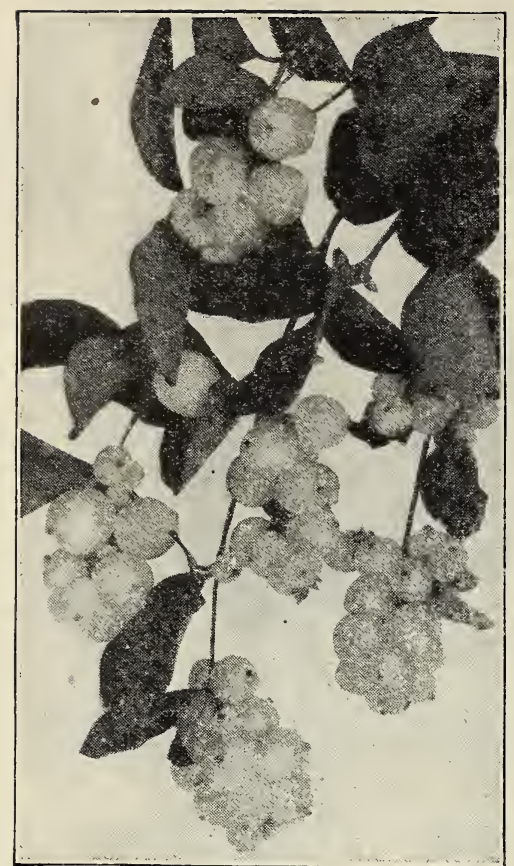

Snowberry.

\section{Emlong's Selected}

Shrubs are no doubt the most important part of landscape plantings, as they occupy the part of the picture on a level with the eye. Trees are above the eye level and flowers below it. A wealth of shrubs massed about the house and on property lines will add greatly to the value of property. By careful selection you can have flowers from early Spring until late Fall, and a wide range of colors. Always plant three to five shrubs of each kind for best effect in mass planting, as scattered specimens are not effective. Our low prices make it possible for you to plant extensively this year at a very low cost.

SPIREA VAN HOUTTET, or

Bridal Wreath. This is the most popular flowering shrub. The small white flowers are borne in clusters and the whole bush takes the appearance of a graceful white fountain during May and June. Leaves red and yellow in the Fall. Thrives anywhere. Price, 2-yr. bushes, $15 \mathrm{c}$ each; 10 for $\$ 1.00$. $3-\mathrm{yr}$. bushes, 35c each; 3 for $\$ 1.00$.

\section{SPIREA ANTHONY WATER-}

ER. Crimson flowers in large clusters, and beautiful variegated foliage make this shrub distinctive. Flowers remain several

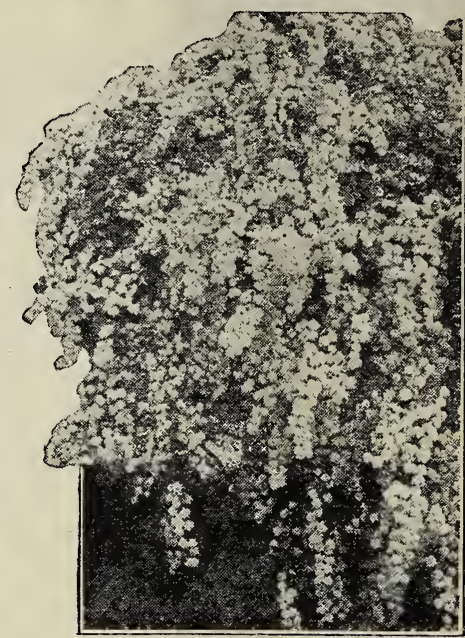

Spirea Van Houttei. weeks. Bush small, fine for mass planting. Price, 2-yr. heavy bushes, $40 \mathrm{c}$ each; 3 for $\$ 1.10$.

SYRINGA, or Mock Orange. A tall, vigorous bush. Fragrant white flowers in May, resembling orange blossoms. Abundant dark green foliage. Does well in shady places. Fine for cutting. Price, 3-yr. strong bushes, $35 \mathrm{c}$ each; 3 for $\$ 1.00$.

SNOWBERRY. A popular, graceful shrub of medium height, having small pink flowers in Spring. Large, snow-white berries in Fall which hang on nearly all Winter. Beautiful if grouped with Indian Currant. Price, 2-yr. heavy bushes, 35c each; 3 for $\$ 1.00$.

(For Flowering Trees see page 45).
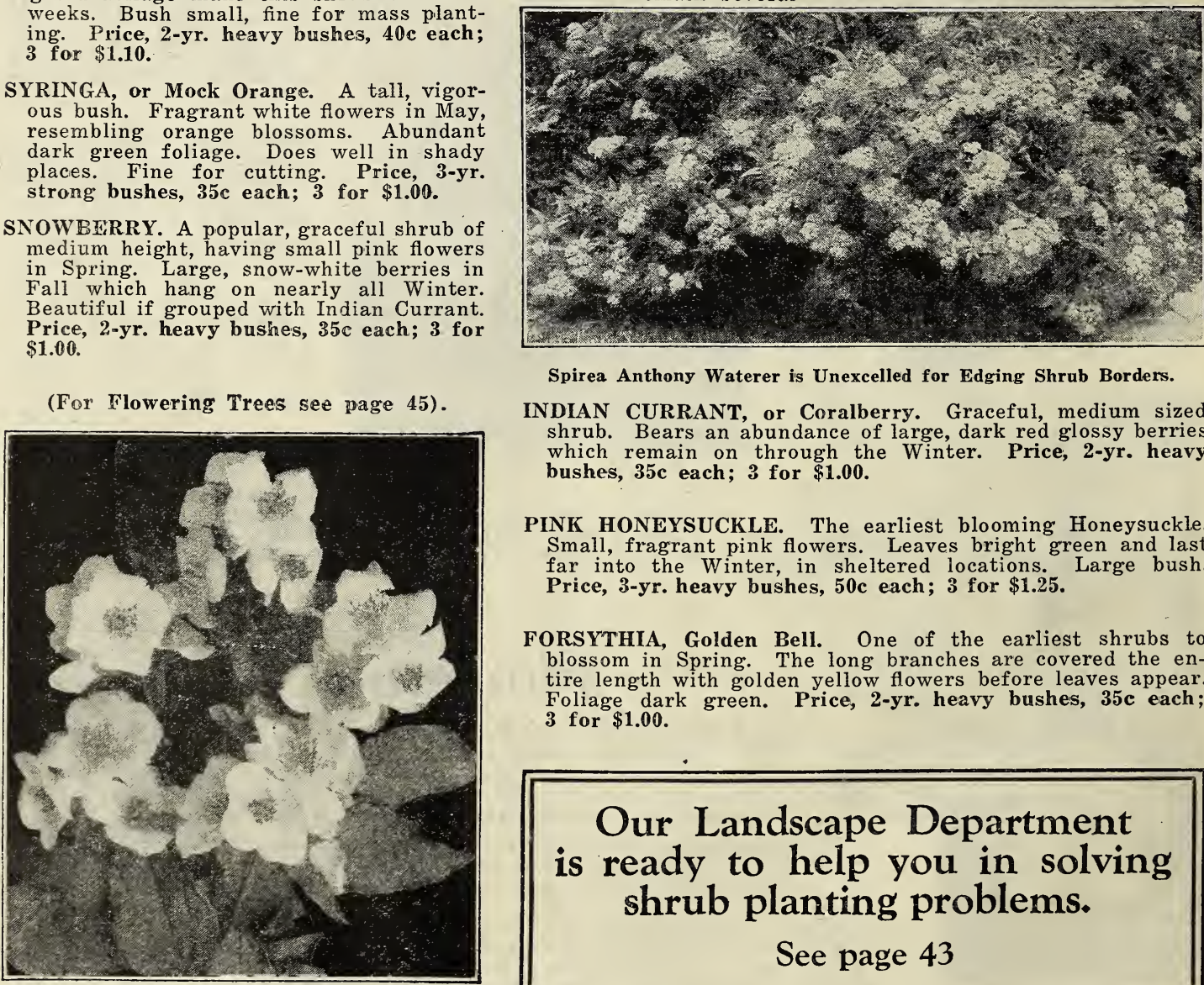

Spirea Anthony Waterer is Unexcelled for Edging Shrub Borders.

INDIAN CURRANT, or Coralberry. Graceful, medium sized shrub. Bears an abundance of large, dark red glossy berries which remain on through the Winter. Price, 2-yr. heavy bushes, 35c each; 3 for $\$ 1.00$.

PINK HONEYSUCKLE. The earliest blooming Honeysuckle. Small, fragrant pink flowers. Leaves bright green and last far into the Winter, in sheltered locations. Large bush. Price, 3-yr. heavy bushes, 50c each; 3 for $\$ 1.25$.

FORSYTHIA, Golden Bell. One of the earliest shrubs to blossom in Spring. The long branches are covered the entire length with golden yellow flowers before leaves appear. Foliage dark green. Price, 2-yr. heavy bushes, 35c each; 3 for $\$ 1.00$.

\section{Our Landscape Department is ready to help you in solving shrub planting problems.}

See page 43 


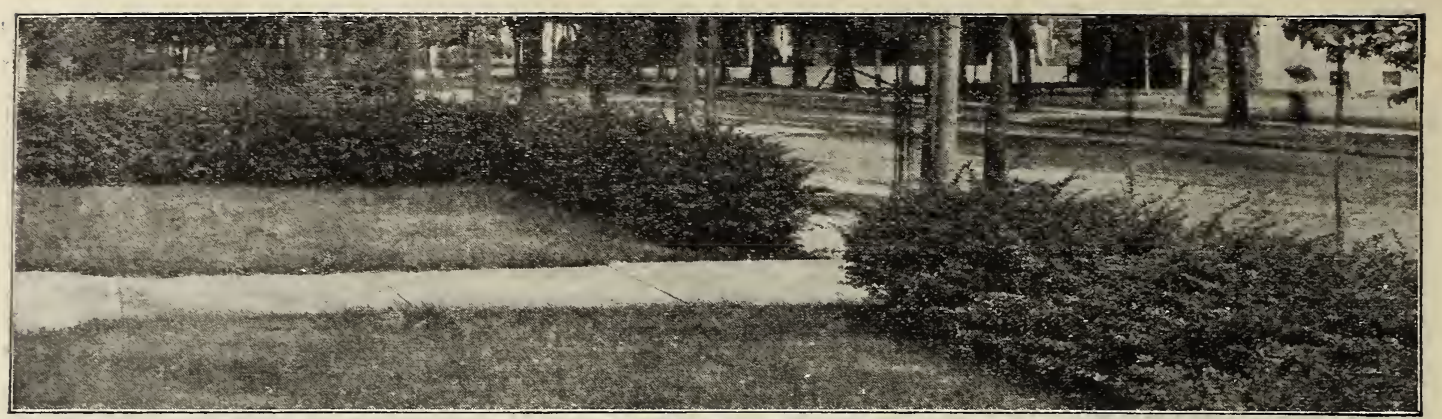

Japanese Barberry Hedge.

\section{Hedge Plants and Climbing Vines}

Can you imagine anything more beautiful and fascinating than a living fence. That's what a hedge is. How much more friendly than the old-fashioned wood and iron fences! As modern ways of planting call for a clear view of the house front, nothing is better than a neatly trimmed hedge along the borders of property. A walk or drive bounded by hedges is charming.

AMOOR RIVER PRIVET. This is the hardiest of all privets and especially desirable for planting in the North. Not subject to blight. In warm climates it is nearly evergreen, and even in the North the foli-. age remains far into the Fall. Glossy green leaves. Privets may be trimmed to any desired height and shape. Price, heavy 2-yr. stock, 10 for $\$ 1.00 ; \$ 6.50$ per 100 .

CALIFORNIA PRIVET. This variety has long been recognized as one of the best and most beautiful plants for hedges. It makes a quick, strong growth and is free from insects and scale. Leaves are dark, glossy green. Price, heavy 2-yr. stock, 10 for $75 \mathrm{c} ; 100$ for $\$ 5.00$.

JAPANESE BARBERRY. The Improved Thunberg's Barberry that is entirely free from rust and may

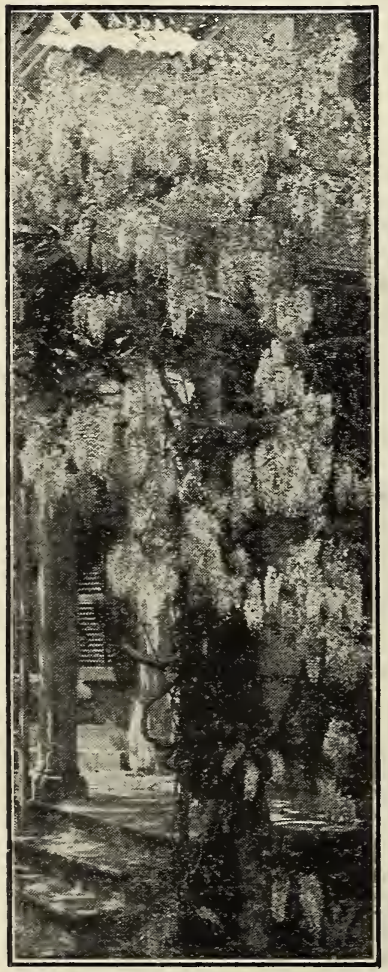

Wisteria.

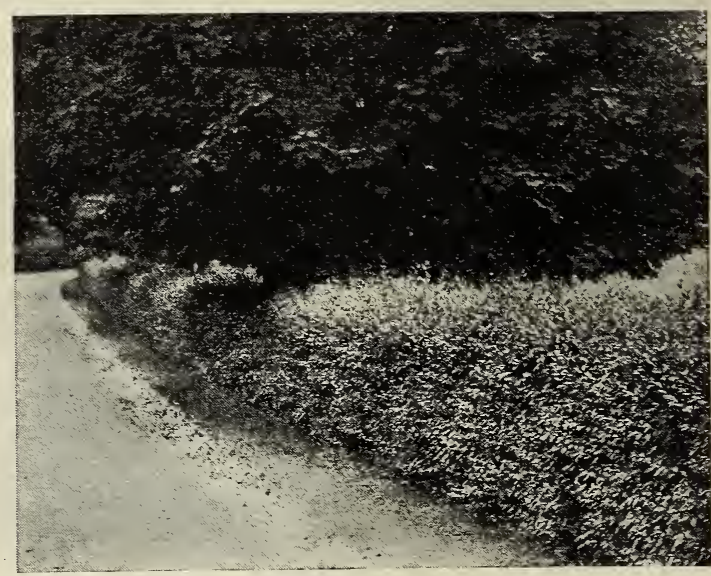

Amoor River Privet Hedge. be planted in any state. A beautiful plant, whether used for group planting, shrub masses or hedges. Foliage bright green, turning to reddish bronze in Fall. Brighter colors obtained in a sunny location. Branches loaded with scarlet berries in Fall that are retained during Winter. Price, 15c each; 8 for $\$ 1.00 ; 100$ for $\$ 12.50$.

SPECIAL NOTE: A unique hedge may be made by planting Japanese Barberry with Spirea Van Houttei (described on next page). Alternate three Barberry then three Spirea Van Houttei and plant in a straight line. Keep the Spirea pruned to a height about 6 to 8 inches greater than the Barberry.

\section{Climbing Vines}

What picture clings in the mind like a vine covered cottage? A few carefully placed vines will lend luxuriant charm to your home.

BOSTON IVY. The very best vine for climbing on buildings. Clings firmly to walls. Three lobed leaves, green in Spring but turning brilliant shades of red in Fall. Blue berries. Hardy vine. Prefers cool place but does well anywhere. Price, 50c each; 3 for $\$ 1.40$.

DUTCHMAN'S PIPE. Tall growing vine with large heart-shaped leaves. Recommended for porches and arbors as it makes a quick shade. Flowers pipe shaped, yellowish brown color. Likes sun at least part of day. Price, 60 c each; 3 for $\$ 1.75$.

CHINESE WISTERIA. Rapid growing vine having compound leaves. Produces an abundance of purple pea-shaped flowers borne in loose clusters. 8 to 12 inches long. Viery showy. Price, 50c each; 3 for $\$ 1.40$.

CLEMATIS PANICULATA. A vigorous, hardy climber adapted for porch coverings, arbors and trellises. Compound, light green leaves. Covered in September with a mass of small white flowers. Price, 50c each; 3 for \$1.40.

NOTE: Climbing vines prefer rich, moist soil. Do not place them closer than 20 inches from the foundation of buildings. 


\section{Special Values in Shrub Collections}

By purchasing shrubs in groups as offered below you will save money on your order. Customers who can only plant a few shrubs this season will find these offers especially attractive, and anyone can afford to buy at least one or two of them. Start THIS YEAR to make a HOME out of your HOUSE by planting around the foundation, then add to the picture each year by making border plantings, adding vines, trees, evergreens, roses, etc. Can you afford to have a barren and cheerless yard when it may be "dressed up" at such a low cost?

We have selected varieties of shrubs having different flowering seasons, and different colored blooms to give a variety. These shrubs are the same sizes and quality as those offered on pages 46 , 47 and 48 . No changes will be made in varieties offered, but if you wish extra stock please order it separately. One of these bargains with a few rose bushes, glad bulbs, trees and a vine $\mathrm{cr}$ two will plant an entire lot in some cases.

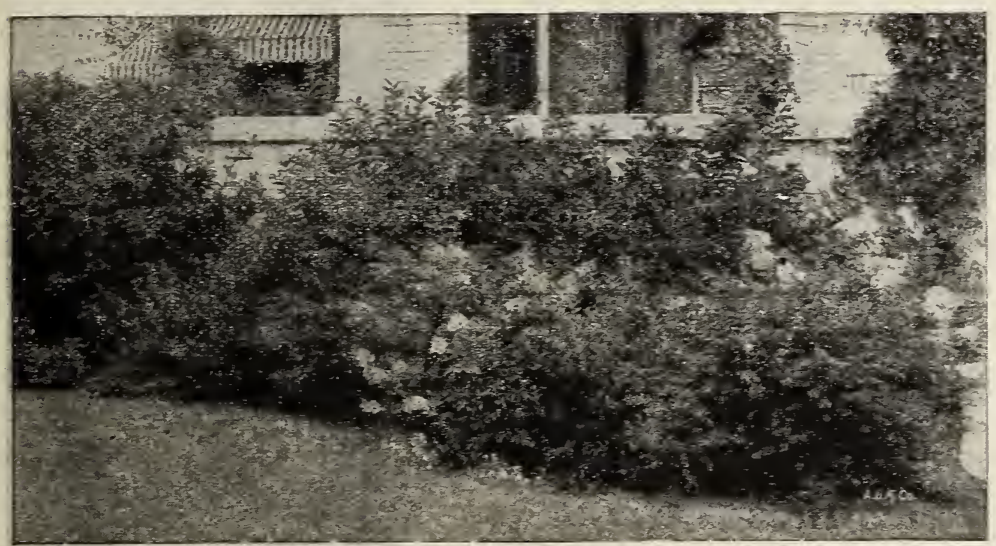

Bargain Ne. 1, Described Above. A Delightful Arrangement.

\section{Bargain No. 1}

Foundation planting, as shown in picture.

6 Syringa, Mock Orange

6 Spirea Anthony Waterer

3 Snowberry

3 Hydrangea P. G.

Complete List Only.

\section{$\$ 5.50$}

Any collection offered on this page will make a showing equal to the one pictured, or better.

\section{Bargain No. 2}

12 Spirea Van Houttei 12 Japanese Barberry 6 Hydrangea P. G.

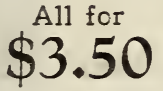

The above three shrubs are without doubt the most popular that we offer. For best effect arrange the Spirea in the background, then place the Hydrangea in groups of three, leaving the edges of the planting curved. Use the Barberry as a border for the planting.

\section{Bargain No.3 \\ 12 Spirea Van Houttei \\ 8 Hydrangea P. G. \\ 3 Lilac, Purple \\ 3 Forsythia, Golden Bell \\ Complete Planting
Only 4.50 \\ Place the Lilacs at corner of the building or end of border. Spirea in background with For- sythia; Hydrangea in front.}

NOTE: The planting pictured at the top of page 43 may be purchased on request. We will furnish a list of shrubs, trees, vines, evergreens, etc., used in same. If you place an order for the entire list, we will send you a planting plan, neatly drawn in India Ink ABSOLUTELY FREE. This is a Landscape Design of rare beauty!

If you wish help in working out the details of your plantings, or in laying out the complete grounds, remember that our IANDSCAPE DEPARTMENT is ready to help you. See terms on page 43.

\section{Bargain No. 4}

6 Spirea Van Houttei

6 Spirea Anthony Waterer

3 Deutzia, Pride of Rochester

3 Butterfly Bush

The Complete Planting as $\$ 4.60$
Described Above Only.... $\$ 4.60$

Arrange the tall shrubs, as Spirea Van Houtte and Deutzia, to the back: Place Spirea Anthony Waterer in the foreground and use the Butterfly Bushes in a group at the end, or in the corner of the building.

\section{Bargain No. 5}

1 Flowering Dogwood (White) Tree

1 Bechtel's Flowering Crab

1 Golden Elder

3 Snowball Bushes

3 Lilac; 2 Purple, 1 White

3 Weigela Rosea

3 Indian Currant

3 Hydrangea P. G.

1 Butterfly Bush

Such a bargain was never offered before. What a mass of beautiful foliage and blossoms will be produced by the above plants.

We have selected mostly tall growing shrubs, having different colored blooms and blooming seasons. This collection will extend along a property line 50 to 60 feet long, or more, according to arrangement. Wouldn't it be more charming than an ordinary fence? It could also be arranged as a foundation planting, or as a screen for some objectionable building or scene.
Complete Planting

$\$ 6.95$ 


\section{America's Finest Gladioli}

Your flower garden is not complete without these glorious bulbs. If you cannot have a separate flower garden they can be planted at the edge of shrub borders or foundation plantings. "Glad" bulbs may be planted in the Spring as soon as the frost is out of the ground, and bloom continuously from July until frost. They do well on any good soil, and are easy to grow. For best success set the bulbs about four to six inches apart, and four inches deep in the ground. Our bulbs are first class, flowering size and will bloom this Summer.

\section{Extra Large Flowering, Special Bred Glads}

AUTUMN QUEEN. Cream yellow, upper petals suffused with lovely pink. Red blotch in throat.

CRIMSON GLOW. Bright, glistening red. Large flower. Tall spikes. Most popular red on the market.

EVELYN KIRTLAND. Lovely rose-pink with lighter shadings. Taill, straight spikes.

PRINCE OF WALES. The choicest of all salmon varieties. Shades to orange. Early flowering.

HERADA. Mauve shaded to purple. Extra large flower. Very attractive. MYRA. A new Hybrid. Deep salmon over yellow ground. Tall stem, extra showy.

Price of all varieties listed above: 10 c each; 12 for $\$ 1.00 ; 25$ for $\$ 1.75$.

\section{GLAD OFFER No. 1}

Three bulbs each of the above six varieties, 18 in all. . $\$ 1.50$ Five bulbs each of the above six varieties, 30 in all...
GLAD OFFER No. 2
GLAD OFFER No. 3

Ten bulbs each of the above six varieties, 60 in

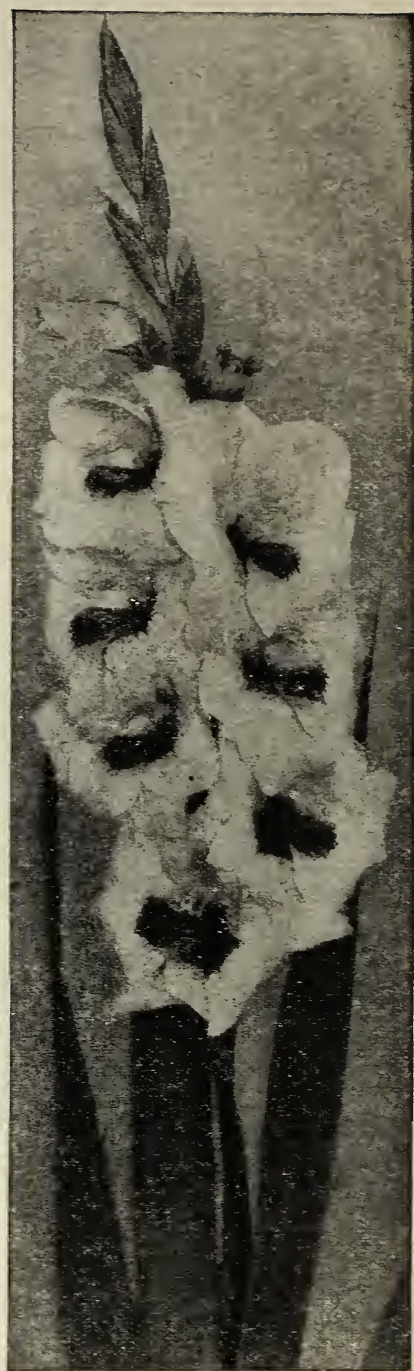

Gladiolus, America. GLAD OFFER No. 5
Five bulbs each of the above six varieties, the above six varieties, Three bulbs each of the above six varieties, 18 in $\$ 1.00$ all........\$1.50
$\$ 2.50$

all...........\$1.00 all.......... $\$ 1.50$ all.......... $\$ 2.50$

\section{NOTE: No discount from prices on this page.}

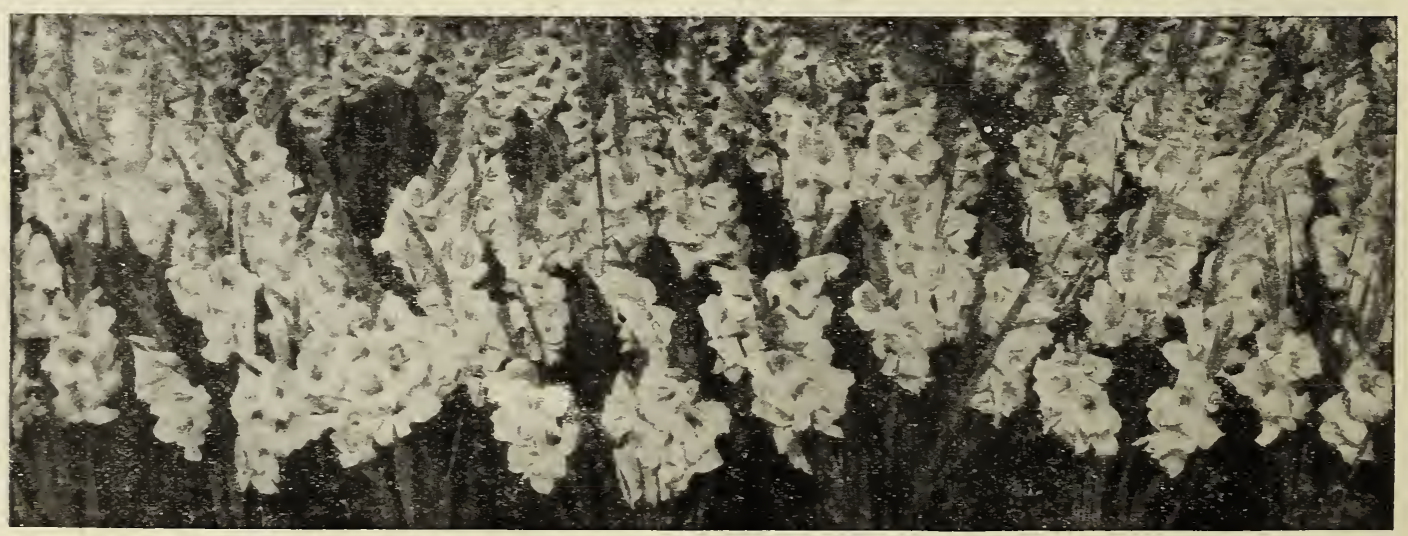




\section{It's Safe to Buy from Emlong's - You Get the Best at a Fair Price}

Don't let anyone fool you with low or bargain priced Nursery Stock. You will only be disappointed if you plant it. To be successful in the fruit business you must plant the healthiest, thriftiest plants and trees, of the most productive nature.

If you plant bargain priced stock you are wasting both your time and money, and if you pay extremely high prices you are at least wasting part of your money. Here is an extract from a letter we received just this morning:

\footnotetext{
"The plants and trees received from you folks last Spring have all made a wonderful growth, in fact much better than stock bought from another Nursery that cost nearly twice as much."
}

We claim that our stock is the best that money can buy, because it is the best that can be grown. The "bargain priced" fellow couldn't give you this quality if he tried, and it's impossible for the "high priced" fellow to give you any more.

Every dollar you invest in EMLONG'S QUALITY STOCK will bring you the greatest return possible because our prices represent HONEST VALUE. Long experience, quantity production, up-to-date facilities and equipment, ideal soil and natural conditions, trained help and above all the desire to treat every customer just as we would like to be treated-these are a few of the reasons WHY we say that it is safe for you to trade with us.

\section{Special Discount for Early Orders}

For your own protection we urge you to send in your order as early as possible. If you wait until late in the season we may be out of some of the items you want, when our present supply is gone we cannot "make" more. It will take a year or more to grow it. It is to our mutual advantage to have you order early-you are sure to find what you want and it is a big help to us as we can handle the "office part" of the work before our rush season.

As a special inducement to get you to order at once we will allow a cash discount of $7 \%$ on January orders and $5 \%$ on orders received during February and the first 10 days in March. No discount after March 10th. We acknowledge your order the same day it is received and your stock will be reserved until planting time.

\section{Make Out Your Order Carefully}

We are anxious to give you prompt efficient service and you can aid us greatly if you will write plainly and give all information asked for on the order blank (page 53). When orders amount to $\$ 5.00$ or less our terms are cash with order. On larger orders we will book the order with a cash payment of $\$ 5.00$, balance can be remitted any time before shipment is wanted.

\section{Remittance May be made by check, postal or express money orders or cash in registered letters. No order booked for less than $\$ 1.00$.}

References More than 100,000 satisfied References customers, any bank in Berrien County, Michigan, or Dun's and Bradstreet's Commercial Agencies.

\section{A Free Gift For You}

Whether you send us an order or not write below the names and addresses of your friends who you think would be interested in our catalog. To repay you for this favor we will send you something you will appreciate.

PLEASE NOTICE. Send us only the names of persons who have farms, yards, or gardens. We are on the square with you and want you to be with us.

Name.

Name.

Name.

Name.

Name.
Address

Address

Address

Address.

Address
R. F. D. or Street.

..R. F. D. or Street..

R. F. D. or Street

R. F. D. or Street

R. F. D. or Street. 


\section{Emlong's}

\section{FAIR PRICES}

We pack and deliver goods to Post Office or express car at prices quoted but do not pay transportation charges, this simply cannot be done in fairness to everyone as the customer living within 1000 miles of us would help pay the charges on orders going two or three thousand miles. On strawberry plants the charges will be about 50 cents per 1000 plants for each 500 miles and in proportion on other stock.
As we are the World's largest growers of this class of stock we are prepared at all times to handle your order quickly and efficiently. Our Nurseries comprise over 400 acres and last season nearly 150 acres was devoted to Fruit Plants alone. As this stock is all grown for PLANTS ONLY and has not been weakened by fruiting you are sure to get plants that are full of life and vigor, healthy and $100 \%$ productive.

\section{PARCEL POST}

For small orders we recommend Parcel Post as the cheapest method of shipment. We ship all mail orders C. O. D. for the postage, as this assures prompt handling and automatically insures the parcel. If you live in the city or on a rural route the stock will be delivered RIGHT TO YOUR DOOR. Our stock is all carefully pruned and cleaned which reduces the Parcel Post and Express charges to the minimum.

Important Every plant we offer is perfect flowering and does not require mating. We have eliminated all female or pistillate varieties as we do not consider them desirable for either home use or commercial purposes. You can grow any variety we offer, alone with good results, or several together if you prefer.

\title{
Strawberry Plants
}

\begin{tabular}{|c|c|c|c|c|c|c|c|c|c|c|c|}
\hline SE? & $\begin{array}{l}\text { DUNIAAP } \\
\text { GIBSON }\end{array}$ & DR & $\begin{array}{l}\text { BURRILL } \\
\text { AROMA }\end{array}$ & & $\mathbf{R}$ & & $\begin{array}{l}\text { COOPER } \\
\text { PEARL }\end{array}$ & & EST KING & & $\begin{array}{l}\text { RFECTED } \\
\text { ASTODON }\end{array}$ \\
\hline 25 & Plants. $\$ 0.30$ & 25 & Plants. $\$ 0.40$ & 25 & Plants.\$0.50 & 25 & Plants. $\$ 0.60$ & 25 & Plants. $\$ 1.00$ & 25 & Plants. $\$ 1.00$ \\
\hline 50 & .50 & 50 & Pla & 50 & Plants. & 50 & Plants. & & 1.40 & 50 & Plants. 1.75 \\
\hline 75 & $\mathrm{Pl}$ & 75 & $\mathrm{Pl}$ & 75 & Plants. 1.05 & 75 & ts. 1.15 & 5 & 1.70 & 75 & $\mathbf{P l}$ \\
\hline 100 & Plants. & 100 & ts. 1.05 & 100 & Plants. 1.25 & 100 & ts. 1.40 & 100 & ts. 2.00 & 100 & s. 2.75 \\
\hline 150 & ts. 1.15 & 150 & s. 1.35 & 150 & Plants. 1.65 & 150 & ts. 1.80 & & ts. 2.85 & 150 & s. 3 \\
\hline 200 & s. 1.50 & 200 & ts. 1.6 & 200 & ts. 2.0 & 200 & Pl & 200 & $\mathbf{P}$ & 200 & $\mathbf{P}$ \\
\hline 250 & ts. 1.80 & 250 & s. 2.05 & 250 & Plants. 2.40 & 250 & s. $\mathbf{2 . 5 5}$ & 250 & 4.35 & 250 & $\mathbf{P}$ \\
\hline 200 & Pla & 30 & ร. 2. & 30 & Pl & 300 & $\mathrm{Pl}$ & 300 & $\mathbf{P}$ & 300 & \\
\hline 40 & Pla & 40 & s. 2.7 & 40 & Pl & 400 & s. 3 & 400 & & 400 & $\mathbf{P}$ \\
\hline & Plants. 2.50 & 50 & 2.85 & 500 & 5. 3.40 & 500 & Pl & 50 & & 500 & \\
\hline & Pla & & $\mathrm{Pla}$ & & & & & & 10 & & \\
\hline & Pla & & s. 10 . & 2000 & 12.50 & 20 & Pl & 20 & & & \\
\hline & Pla & 30 & Pla & & & & Pl & & & & \\
\hline & $\mathrm{Pla}$ & & Pla & 40 & & & Pl & & & & \\
\hline & Pla & & nts. & 0 & Plants.2 & & rants. & & lants. 48.75 & 5000 & Plants.75.00 \\
\hline
\end{tabular}
Red Raspberries

\begin{tabular}{|c|c|c|c|c|c|c|c|c|c|}
\hline $\begin{array}{l}\text { Early King } \ldots \ldots \ldots \ldots \ldots . \$ 0.60 \\
\text { Cuthbert } \ldots \ldots \ldots \ldots \ldots \ldots \ldots\end{array}$ & $\begin{array}{r}25 \\
\$ 1.00 \\
1.15 \\
1.25 \\
1.50 \\
1.25\end{array}$ & $\begin{array}{l}50 \\
\$ 1.65 \\
1.85 \\
2.00 \\
2.50 \\
2.00\end{array}$ & $\begin{array}{r}75 \\
\$ 2.25 \\
2.45 \\
2.65 \\
3.25 \\
2.65\end{array}$ & $\begin{array}{r}100 \\
\$ 2.75 \\
2.95 \\
3.25 \\
4.50 \\
3.25\end{array}$ & $\begin{array}{l}200 \\
\$ 5.00 \\
5.65 \\
6.00 \\
8.00 \\
6.00\end{array}$ & $\begin{array}{r}300 \\
\$ 6.50 \\
6.85 \\
7.50 \\
10.75 \\
7.50\end{array}$ & $\begin{array}{r}400 \\
\$ 7.75 \\
8.25 \\
9.25 \\
12.85 \\
9.25\end{array}$ & $\begin{array}{l}500 \\
\$ 8.50 \\
9.50 \\
10.50 \\
15.50 \\
10.50\end{array}$ & $\begin{array}{l}1000 \\
\$ 16.00 \\
18.00 \\
20.00 \\
30.00 \\
20.00\end{array}$ \\
\hline 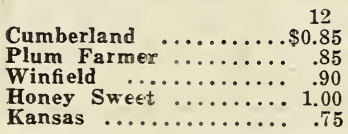 & $\begin{array}{l}25 \\
\$ 1.25 \\
1.25 \\
1.35 \\
1.50 \\
1.15\end{array}$ & $\begin{array}{c}50 \\
\$ 2.00 \\
2.00 \\
2.25 \\
2.50 \\
1.85\end{array}$ & $\begin{array}{r}75^{2} \\
\$ 2.65 \\
2.65 \\
2.90 \\
3.25 \\
2.45\end{array}$ & $\begin{array}{l}100 \\
\$ 3.25 \\
3.25 \\
3.50 \\
4.50 \\
2.95\end{array}$ & $\begin{array}{c}200 \\
\$ 6.00 \\
6.00 \\
6.50 \\
8.00 \\
\mathbf{5 . 6 5}\end{array}$ & $\begin{array}{r}300 \\
\$ 7.50 \\
7.50 \\
8.75 \\
10.75 \\
6.85\end{array}$ & $\begin{array}{r}400 \\
\$ 9.25 \\
9.25 \\
11.00 \\
12.85 \\
8.25\end{array}$ & $\begin{array}{r}500 \\
\$ 10.50 \\
10.50 \\
13.00 \\
15.50 \\
9.50\end{array}$ & $\begin{array}{r}1000 \\
\$ 20.00 \\
20.00 \\
25.00 \\
30.00 \\
18.00\end{array}$ \\
\hline
\end{tabular}

\section{Blackberries}

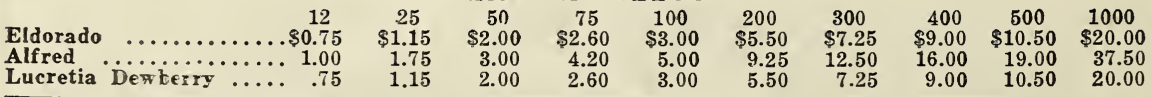

\section{Your Money's Worth or Your Money Back}

Years of experience in which we have grown and handled millions of plants and trees and filled thousands of orders has taught us how to do it best. That is why we can guarantee every order to reach you in perfect condition, and every plant or tree to be $100 \%$ pure and true-to-name. If you find it otherwise tell us about it and get your money back. You are taking no chances when you deal with us.

\author{
MEMBERS AMERICAN ASSOCIATION OF NURSERYMEN \\ MEMBERS MICHIGAN ASSOCIATION OF NURSERYMEN
}

For Your Protection Buy From a Member

Don't Let
Low
Prices
Fool You
The Cost of
Your Plants is
Nothing Com-
pared to the
Value of a Good
Crop of Fruit.
The Few Cents
Extra You Pay
for Our
Young Healthy
Vigorous Plants
and Trees Will
Come Back
OMany Times
Not Only in
Quantity But
Also in Quality.




\section{We Guarantee Absolute Satisfaction}

Every order we send out carries our absolute guarantee of satisfaction. Mistakes with us are very rare but should any occur in filling your order we replace the stock free of charge or refund the purchase price, just as you prefer, but in no case will we be liable for more than the original purchase price. You will get your money's worth because we are not satisfied until you are.

Our shipping season opens in March and continues through April and May. Order early while our stock is complete. Write plainly and always give complete name and address.

Our No.

ORDER BLANK

Checked by.

\section{Henry Emlong \& Sons, Stevensville, Mich.}

Date.

Enclosed find \$.

for which send me the goods named in this order.

My Name.

Post Office

State.

R. F. D. No.

Street and No.

If by Express, ship to.

(Town for Express)

County

Shipping Date

Ship by

(Express or Mail)

(When to Ship)

IMPORTANT. When ordering late in the season, please state whether we shall substitute some-
. Wh we substitute (Yes or No)

\section{When Ordering Trees or Shrubs State Size or Grade Wanted}

Quantity

If additional space is required, continue your order on any ordinary writing paper. 


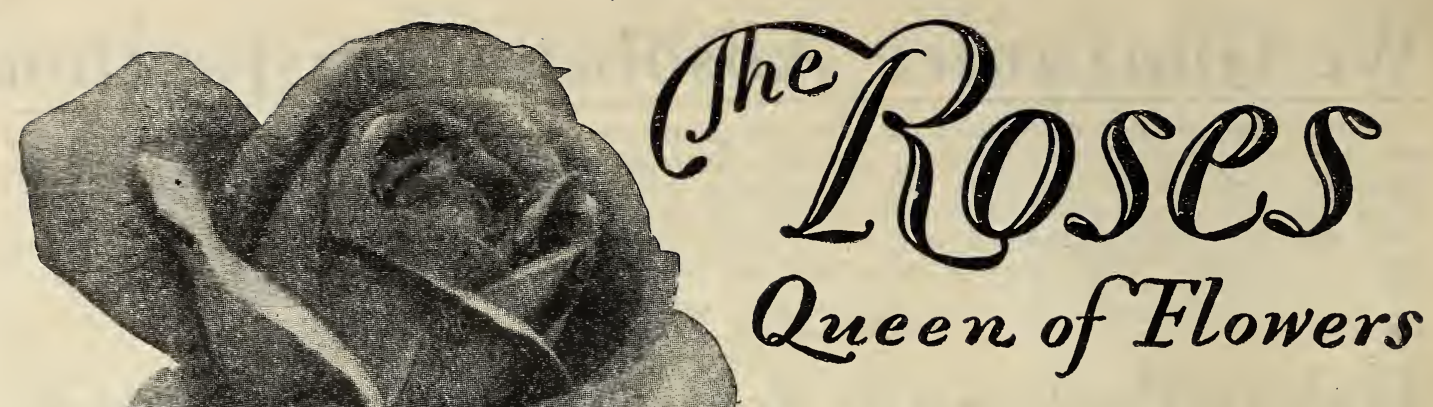

No other flower is so universally loved as the Rose. The patient work of years has developed this once modest, white flower in to such a variety of shapes, sizes and colors that everyone may choose their favorites. We have selected for our customers the varieties which have proven most popular, are the hardiest and most profuse bloomers. Our bushes are sturdy, well rooted, two-year field-grown stock, with tops 20 to 30 inches. Well branched. (H. T. designates Hybrid Teas; H. P. Hybrid Perpetuals).

American Beauty.

GENERAL JACQUEMINOT. H. P. Fiery red, of magnificent form and color. Richly fragrant and one of the most profuse bloomers.

FRAU KARL DRUSCHKI. white rose yet introduced. Queen by solme admirers. cately formed flowers.

AMERICAN BEAUTY. H. T. The best known American rose and a prize-winner everywhere. Deep pink approaching crimson color. Exquisite form and fragrance. Large blossoms.

MRS. AARON WARD. H. T. Delicate, creamy yellow, shading to orange. Deeply cupped buds. Very popular.

GRUSS AN TEPLITZ. H. T. Every rose lover shauld plant this variety. "One of the freest bloomers, very hardy. Brilliant crimson color.
PAUL NEYRON. H. P. Commonly known as the Peony rose because of the immense, double blooms. Rich, ruddy pink. Blooms from June until November. A very hardy, sturdy rose. No rose garden complete without it.

LOS ANGELES. H. T. One of the finest roses of American origin. Flowers large and continuous. Flame-pink, shaded with coral and gold at base of petals. A rare beauty.

PREMIER. H. T. A magnificent variety of large size and distinct shape. Rose-pink color. Outer petals form a broad roll, creating interesting color changes. Nearly thornless.

Price of all Hybrid Perpetuals and Hybrid Teas: $50 \mathrm{c}$ each; 3 for $\$ 1.35 ; 10$ for $\$ 4.00$.

\section{RAMBLER AND CLIMBING ROSES}

For the porch, arbor or pergola, Climbing Roses produce a wonderful covering of delicate foliage and fragrant flowers. The following varieties are very hardy and need little if any Winter protection. May be pruned severely if they grow too rank, as this increases the number of blossoms. CRIMSON RAMBLER. One of the best. Flowers borne in large clusters, completely covering the entire length of the vine. May be used as a climber or pruned into a large bush. Crimson-red blooms.

DOROTHY PERKINS. Shell-pink flowers which grow in large clusters. Very free bloomer. Flowers very double and sweet scented. The finest

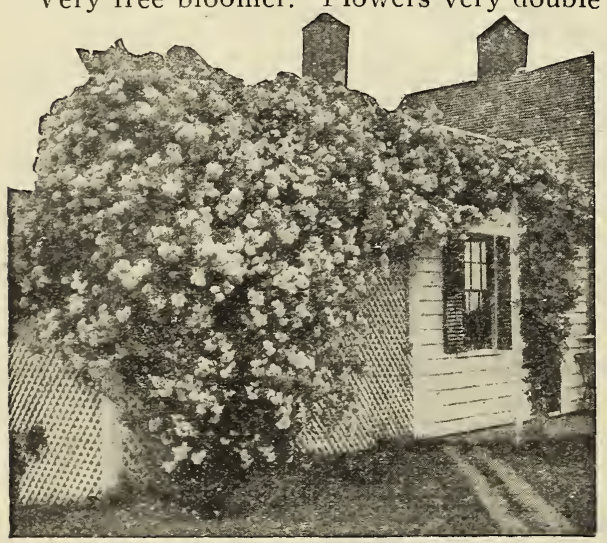

Dorothy Perkins Rambier. pink Rambler.

\section{AMERICAN BEAUTY} CLIMBER. One of the best Climbers. Blooms early and produces an abundance of fragrant, rich pinkish crimson flowers. Perfectly hardy. Price, the above ramblers and climbers: Strong 2-yr. plants, 35c each; 3 for $\$ 1.00$; 10 for $\$ 2.85$.

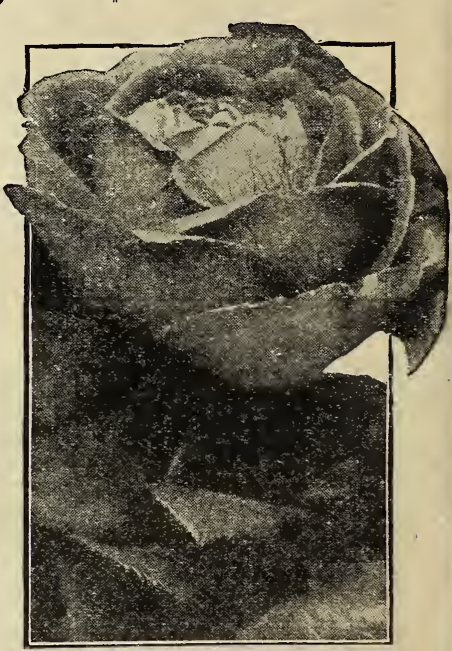

Paul Neyron (1/5 actual size).

PAUL'S SCARLET CLIMBER. By far the finest red Climber in existence. Flowers are large, semi-double and intense scarlet. Never fades in the sun as other climbers do. Blooms very long, holding its flowers after many of the June bloomers have lost their petals. Price, strong, 2-yr. plants, 40c each; 3 for $\$ 1.00 ; 10$ for $\$ 3.00$. 


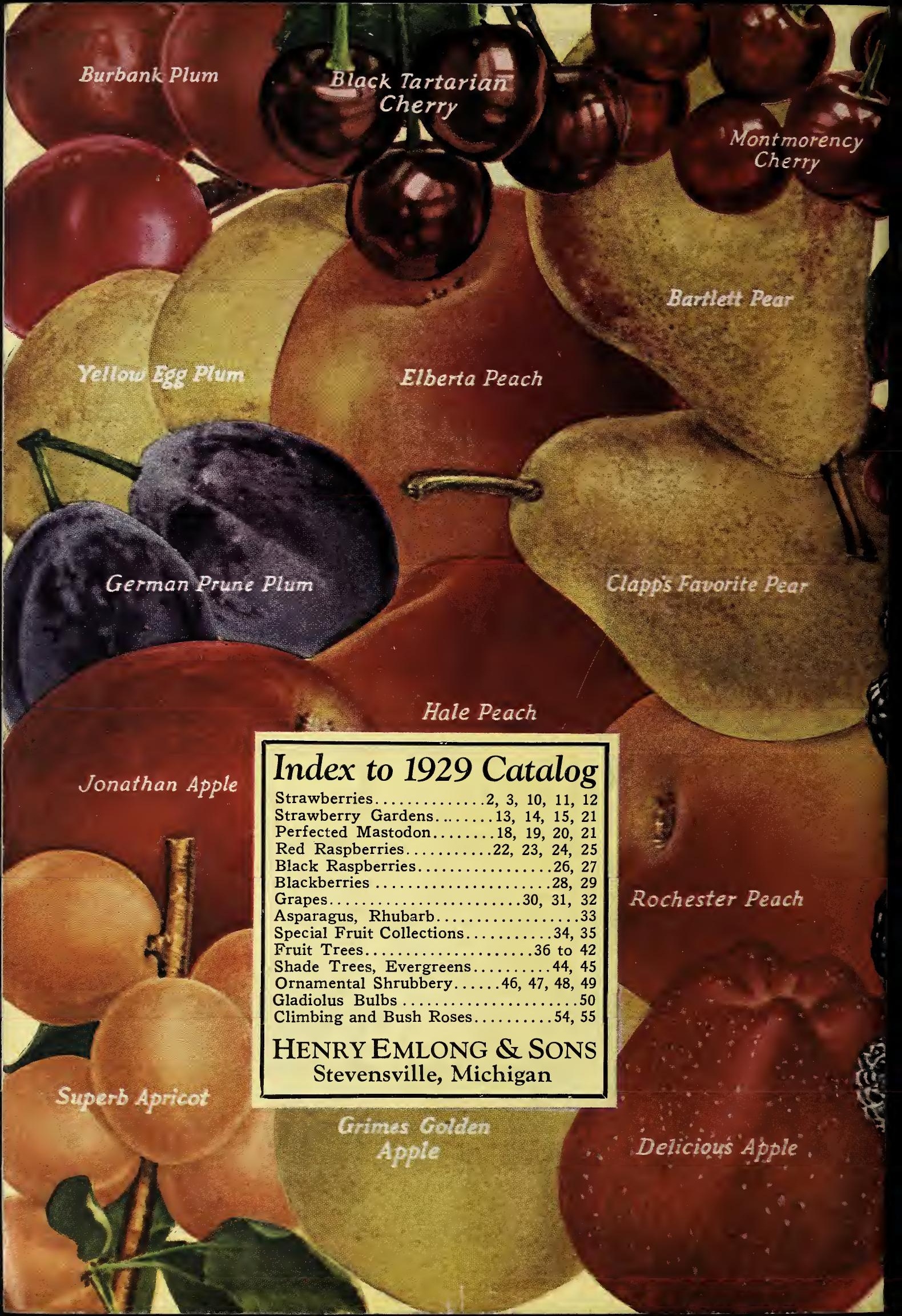

